$$
\begin{aligned}
& D \circ E / P C / 91008-23-P+.6 \\
& \text { Fracture Characterization }
\end{aligned}
$$

and Discrimination Criteria

\title{
for Karst and Tectonic
}

\section{Fractures in the Ellenburger}

\section{Group, West Texas: \\ Implications for Reservoir and Exploration Models}

T. Hoak ${ }^{a}$, K. Sundbergb, P. Deyhim ${ }^{\text {c }}$, and P. Ortolevad

a Kestrel Geoscience, LLC

9683 West Chatfield Avenue, Unit D

Littleton, Colorado 80128

b Phillips Petroleum Company

252 Geoscience Building

Bartlesville, Oklahoma 74003

c Oklahoma State University

Stillwater, Oklahoma 74078

d Laboratory for Computational Geodynamics

Department of Chemistry

Indiana University

Bloomington, Indiana 47405 


\section{DISCLAIMER}

Portions of this document may be illegible in electronic image products. Images are produced from the best available original document. 


\section{Table of Contents}

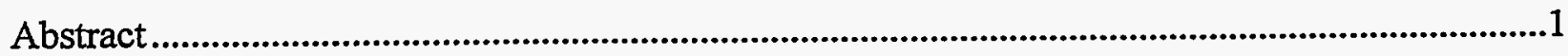

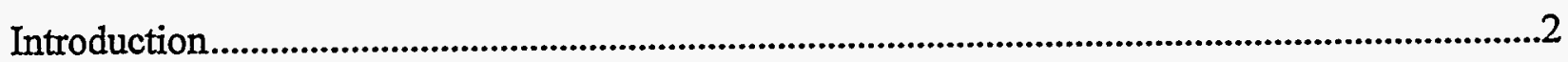

Global Significance of Karsted Reservoirs...................................................................................2

Overview of Previous Research on Karst Reservoirs .....................................................................6

Overview of Andector Field and Ellenburger Group ........................................................................7

Andector Field Overview.........................................................................................................

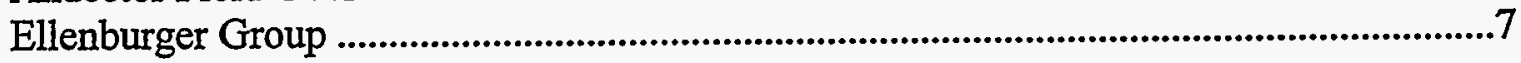

Fracture Genesis Discrimination Criteria ...............................................................................17

Karst Fractures and Related Breccias ..................................................................................17

Tectonic Fractures and Related Tectonic Breccias

Karst Fractures....................................................................................................................18

Tectonic Fractures.....................................................................................................................18

Regional Diagenetic Sequence ................................................................................................25.

Fracture Data Synthesis ................................................................................................................27

Orientation Characteristics of Mineralized Fractures ...................................................................30

Attributes of Mineralized Fractures .......................................................................................38

Fractures Attribute summary: Implications for for reservoir and explorations .............................40

Geochemistry of Fracture Infill ................................................................................................46

Model for Fractured Reservoir Development.................................................................................54

Conclusions \& Implications for Exploration and Development Programs .....................................59

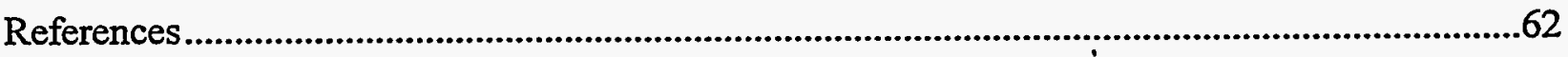

\section{DISCLAIMER}

This report was prepared as an account of work sponsored by an agency of the United States Government. Neither the United States Government nor any agency thereof, nor any of their employees, makes any warranty, express or implied, or assumes any legal liability or responsibility for the accuracy, completeness, or usefulness of any information, apparatus, product, or process disclosed, or represents that its use would not infringe privately owned rights. Reference herein to any specific commercial product, process, or service by trade name, trademark, manufacturer, or otherwise does not necessarily constitute or imply its endorsement, recommendation, or favoring by the United States Government or any agency thereof. The views and opinions of authors expressed herein do not necessarily state or reflect those of the United States Government or any agency thereof. 


\title{
FRACTURE CHARACTERIZATION AND DISCRIMINATION CRITERIA FOR KARST AND TECTONIC FRACTURES IN THE ELLENBURGER GROUP, WEST TEXAS: IMPLICATIONS FOR RESERVOIR AND EXPLORATION MODELS
}

\author{
T.E. Hoak, SAIC and Kestrel Geoscience, LLC, Littleton CO; \\ K.R. Sundberg, Phillips Petroleum Co., Bartlesville OK; \\ P. Deyhim, Oklahoma State University, Stillwater, OK; \\ P. Ortoleva, Lab. for Computational Geodynamics, Indiana University, Bloomington, IN.
}

\begin{abstract}
:
In the Ellenburger Group fractured dolomite reservoirs of West Texas, it is extremely difficult to distinguish between multiple phases of karst-related fracturing, modifications to the karst system during burial, and overprinting tectonic fractures. From our analyses of drill core, we developed criteria to distinguish between karst and tectonic fractures. In addition, we have applied these criteria within the context of a detailed diagenetic cement history that allows us to further refine the fracture genesis and chronology.
\end{abstract}

In our analyses, we evaluated the relationships between fracture intensity, morphologic attributes, host lithology, fracture cement, and oil-staining. From this analysis, we have been able to characterize variations in Ellenburger tectonic fracture intensity by separating these fractures from karstrelated features. In general, the majority of fracturing in the Ellenburger is caused by karst-related fracturing although a considerable percentage is caused by tectonism. These findings underscore the importance of considering the complete geologic evolution of a karst reservoir during exploration and field development programs. Previous studies that emphasized only karst processes have overlooked the potential for enhanced permeability and reservoir connnectivity caused by tectonic fracturing that links together karsted reservoir zones.

We have been able to more precisely define the spatial significance of the fracture data sets by use of oriented core from Andector Field. In this area, we have access to several hundred feet of oriented core (that also penetrates basement) and have been able to compare this data to that collected from other adjacent fields. We have also demonstrated the importance of these results for exploration and reservoir development programs in West Texas, and the potential to extrapolate these results around the globe.

Given the historic interest in the large hydrocarbon reserves in West Texas carbonate reservoirs, results of this study will have tremendous implications for exploration and production strategies 'targeting vuggy, fractured carbonate systems not only in West Texas, but throughout the globe. 


\section{INTRODUCTIÓN:}

In the Permian Basin of West Texas, world-class oil and gas reserves are found in the Ordovician-age Ellenburger Formation (Galloway et al., 1983; Kerans, 1990). The Ellenburger fractured carbonates represent a significant reservoir in both the Delaware and Midland basins, and the Central Basin Platform uplift that separates them (See Figure 1). In all of these mature producing areas, effective primary, secondary and tertiary recovery is stymied by the inability to predict tectonic and karst-related fracture characteristics in advance of drilling, and ambiguous regional controls on reservoir quality.

In Ellenburger reservoirs, anomalously high permeability and enhanced wellbore prodicibility is controlled by natural fractures caused by karst collapse that occurred during late Ordovician sea-level changes. By analogy with modern karst systems, this karst-related fracturing and related breccia zone formation were likely initiated along pre-existing tectonic fractures aligned with basement structure. These karst breccia reservoir facies were subsequently overprinted and interconnected by tectonic fractures formed during Pennsylvanian-age orogeny.

The complexity of producing oil and gas from the Ellenburger play has only been wellunderstood from a theoretical geologic perspective for approximately the last ten years. During that time, a widely-accepted model of karstification and related fracturing and brecciation has become the accepted model (e.g. Loucks and Anderson, 1985; Kerans, 1990; Loucks and Mescher, 1997). Unfortunately, the ability to use this information in a practical exploration and development model is hampered by the lack of three-dimensional information about both the geometry of the karst-related fracture systems on a regional and field scale, and its relationship to the overprinting tectonic fractures. The original karst reservoir models were developed using limited core control restricted to the upper Ellenburger producing interval, and regional cross-sections that do not fully capture the threedimensional complexity of the karst system as suggested by outcrop based studies and analog studies of modern cave and karst systems. However, these studies did outline the primary characteristics of these reservoirs. Most importantly, regional and field-scale studies of tectonic fractures have not been performed to assess the relative importance and role of tectonic fractures to further enhance producibility and connectivity of the karst-related reservoirs. The inability to distinguish between tectonic fractures and karst-related deformation features is a major impediment to fully understanding the relative importance of karst-related fracturing and tectonic fracturing in an Ellenburger fractured reservoir model.

\section{GLOBAL SIGNIFICANCE OF KARSTED RESERVOIRS}

Until fairly recently, the global distribution and significance of karsted reservoirs has been poorly understood. More importantly, the tremendous flow rates and large reserves associated with these systems has not been fully appreciated. Table I (from Mazzullo and Chilingarian, 1996) illustrates the tremendous diversity of karsted carbonate reservoirs. From this data, it can be generalized that a carbonate depositional environment that experiences a relative fall in sea level shortly after deposition of the system, tectonic uplift, and/or an emergence of the depositional system to permit the operation of surficial processes, should experience karstification. In those areas in which the water table has fluctuated over time and the carbonates remain shallowly buried and/or exposed, significant karst dissolution can generate similar effects. This appears particularly important when extrinsic factors such as climate, sea level, and the presence of vegetation interact with favorable intrinsic factors such as lithology, structure, and stratigraphy. Only those carbonate systems that are buried rapidly, experience rapid diagenesis; and never are brought up to the surface or shallow near-surface should avoid karst 
effects. A recent overview paper on karst processes and reservoirs by Mazzullo and Chilingarian (1996) expands on many of these key points.

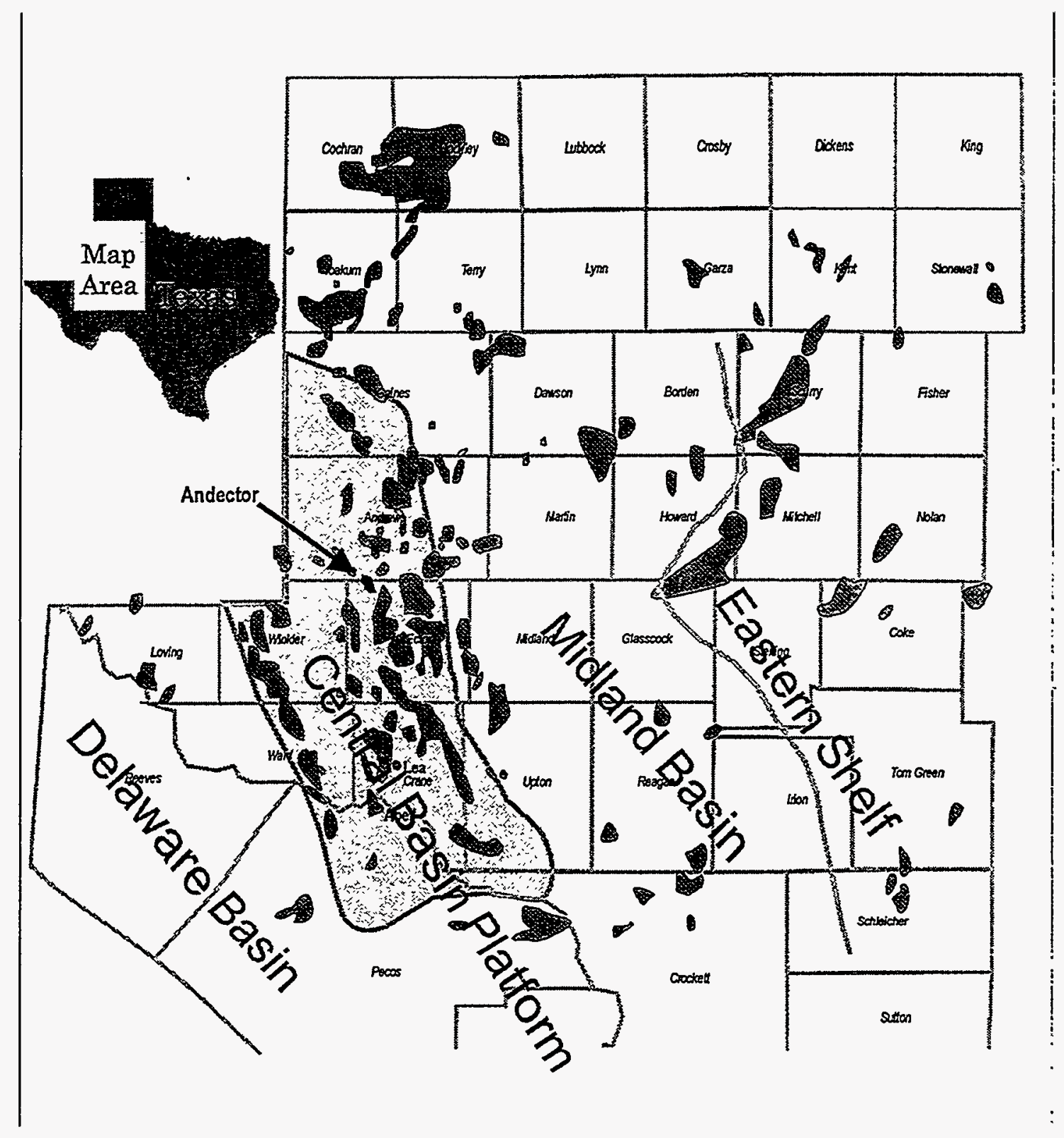

Figure 1: Major West Texas oil fields and regional elements of Permian Basin. Modified after Galloway et al. (1983). 


\section{Table I: Karsted Carbonate Reservoirs (in order of decreasing age) (modified from Mazzullo and Chilingarian, 1996)}

\begin{tabular}{|c|c|c|c|c|}
\hline Field/Trend & Location & $\begin{array}{l}\text { Reservoir age } \\
\text { (unit) }\end{array}$ & $\begin{array}{l}\text { Reservoir } \\
\text { Lithology }\end{array}$ & Reference \\
\hline Various fields & & U. Cambrian & Dolomite & Dolly and Busch (1972) \\
\hline $\begin{array}{l}\text { Kraft-Prusa Trend, } \\
\text { Kansas. }\end{array}$ & & $\begin{array}{l}\text { Cambrian-L. } \\
\text { Ordovician }\end{array}$ & Dolomite & $\begin{array}{l}\text { Walters, (1946; 1958; Walters and Price (1948); Newell } \\
\text { (1987) }\end{array}$ \\
\hline $\begin{array}{l}\text { Cottonwood Creek } \\
\text { Healdton, OK } \\
\text { e.g. Wilburton Field. }\end{array}$ & & $\begin{array}{l}\text { Cambrian-L. } \\
\text { Ordovician }\end{array}$ & Dolomite & $\begin{array}{l}\text { Gatewood (1970); Latham (1970); Wilson (1980a,b; } \\
\text { 1985); Shirley (1988); Hook (1990); Bliefnick and } \\
\text { Belfield (1991); Carpenter and Evans (1991); Lynch and } \\
\text { Al-Shaeib (1991); Waddell et al., (1991) Wilson et al. } \\
\text { (1991, 1992); Bliefnick (1992). }\end{array}$ \\
\hline $\begin{array}{l}\text { Various Fields (e.g. } \\
\text { Renqui). }\end{array}$ & & $\begin{array}{l}\text { Cambiran-M. } \\
\text { Ordovician, } \\
\text { Precambrian }\end{array}$ & $\begin{array}{l}\text { Dolomite, } \\
\text { limestone }\end{array}$ & $\begin{array}{l}\text { Guangming and Quanheng (1982); Li et al. (1982; Qi and } \\
\text { Xie-Pei (1984); Quanheng (1984). }\end{array}$ \\
\hline Various Fields & & $\begin{array}{l}\text { L. Ordovician } \\
\text { (Ellenburger Group) }\end{array}$ & Dolomite & $\begin{array}{l}\text { Mear and Dufurrena (1984); Loucks and Anderson } \\
\text { (1985); Mazzullo and Reid (1986); Ijirigho and Schreiber } \\
\text { (1988); Kerans (1988, 1990); Amthor and Friedman } \\
\text { (1989); S.J. Mazzullo (1989a, b; 1990); Mear (1989a); } \\
\text { Verseput (1989); Holtz and Kerans (1992); Kupecz } \\
\text { (1992); Loucks and Handford (1992). }\end{array}$ \\
\hline $\begin{array}{l}\text { Various Fields (e.g. } \\
\text { New Hope, Fairview, } \\
\text { Maben). }\end{array}$ & & $\begin{array}{l}\text { L-M Ordovician } \\
\text { (Knox Group) }\end{array}$ & $\begin{array}{l}\text { Dolomite, } \\
\text { limestone }\end{array}$ & $\begin{array}{l}\text { Fritz (1991); Henderson and Knox (1991); Raymond and } \\
\text { Osborne (1991). }\end{array}$ \\
\hline Various Fields & & $\begin{array}{l}\text { L.-M. Ordovician } \\
\text { (Prairie du Chien } \\
\text { Group) }\end{array}$ & Dolomite & Nadon and Smith (1992) \\
\hline $\begin{array}{l}\text { Lima-Indiana, Albion- } \\
\text { Scipio,-Pulaski trends, } \\
\text { Northville, Stoney } \\
\text { Point, Trenton fields. }\end{array}$ & & $\begin{array}{l}\text { U. Ordovician } \\
\text { (Trenton-Black } \\
\text { River Group) }\end{array}$ & Dolomite & $\begin{array}{l}\text { Wilson (1980a,b; 1985); DeHaas and Jones (1988); } \\
\text { Catacosinos et al. (1990). }\end{array}$ \\
\hline Dollarhide Field & & $\begin{array}{l}\text { L. Ordovician- } \\
\text { Devonian } \\
\text { (Ellenburger Group, } \\
\text { Fusselman Fm. } \\
\text { Thirtyone Fm.) }\end{array}$ & $\begin{array}{l}\text { Dolomite, } \\
\text { limestone, } \\
\text { triptolitic } \\
\text { chert }\end{array}$ & Stormont (1949), Ruppel and Hovorka (1995). \\
\hline $\begin{array}{l}\text { N. and S. Michigan } \\
\text { pinnacle reef trend } \\
\text { (e.g. Belle River Hills, } \\
\text { Rapid River Hills). }\end{array}$ & & Silurian (Niagaran,) & Dolomite & Mesolella et al., (1974; Gill (1985). \\
\hline $\begin{array}{l}\text { Various Fields (e.g. } \\
\text { Marine Pool, Colmer- } \\
\text { Plymouth, Edinburg } \\
\text { West). }\end{array}$ & . & $\begin{array}{l}\text { Silurian (Niagaran, } \\
\text { some associated } \\
\text { Devonian) }\end{array}$ & $\begin{array}{l}\text { Dolomite, } \\
\text { limestone }\end{array}$ & $\begin{array}{l}\text { Lowenstam (1948); Whting and Stevenson (1965); } \\
\text { Kruger (1992). }\end{array}$ \\
\hline $\begin{array}{l}\text { Star, Lacey, West } \\
\text { Campbell, NE Alden } \\
\text { Fields. }\end{array}$ & & $\begin{array}{l}\text { Silurian, Devonian } \\
\text { (Hunton Group) }\end{array}$ & Dolomite & $\begin{array}{l}\text { Harvey (1972); Withrow (1972); Carpenter and Evans } \\
\text { (1991). }\end{array}$ \\
\hline Various Fields & & $\begin{array}{l}\text { L.-U. Devonian } \\
\text { (Thirtyone Fm.) }\end{array}$ & $\begin{array}{l}\text { Triptolitic } \\
\text { chert, } \\
\text { dolomite, } \\
\text { limestone, }\end{array}$ & $\begin{array}{l}\text { Hovorka and Ruppel (1990); Saller et al. (1991); Cnater et } \\
\text { al. (1992). }\end{array}$ \\
\hline
\end{tabular}




\begin{tabular}{|c|c|c|c|c|}
\hline Field/Trend & Location & $\begin{array}{c}\text { Reservoir age } \\
\text { (unit) }\end{array}$ & $\begin{array}{l}\text { Reservoir } \\
\text { Lithology }\end{array}$ & Reference \\
\hline Grant Canyon Field & $\begin{array}{l}\text { Basin and Range } \\
\text { (USA) }\end{array}$ & $\begin{array}{l}\text { Devonian } \\
\text { (Simonson and } \\
\text { Guilmette fms.) }\end{array}$ & Dolomite ' & Read and Zogg (1988). \\
\hline Bindley Field & $\begin{array}{l}\text { Central Kansas } \\
\text { Uplift (KS) }\end{array}$ & $\begin{array}{l}\text { L. Mississippian } \\
\text { (Warsaw Fm.) }\end{array}$ & Dolomite & Ebanks et al. (1977). \\
\hline $\begin{array}{l}\text { Elk Basin Field (and } \\
\text { others) }\end{array}$ & $\begin{array}{l}\text { Big Horn Basin } \\
\text { (Wyoming) }\end{array}$ & $\begin{array}{l}\text { U. Mississippian } \\
\text { (Madison Fm.) }\end{array}$ & $\begin{array}{l}\text { Dolomite, } \\
\text { some } \\
\text { limestone. }\end{array}$ & McCaleb and Wayhan (1969); McCaleb (1988). \\
\hline $\begin{array}{l}\text { Alida, Daly, Newburg, } \\
\text { Nottingham, Parkman, } \\
\text { South Wsthope, } \\
\text { Virden fields (and } \\
\text { others). }\end{array}$ & $\begin{array}{l}\text { Williston Basin } \\
\text { (Canada and USA) }\end{array}$ & $\begin{array}{l}\text { U. Mississippian } \\
\text { (Mission Canyon } \\
\text { and Madison } \\
\text { Groups). }\end{array}$ & $\begin{array}{l}\text { Limestone, } \\
\text { dolomite. }\end{array}$ & $\begin{array}{l}\text { Edie (1958); Martin (1964; 1966); Illing et al (1967); } \\
\text { Marafi (1972); Wilson (1985); Kent et al. (1988). }\end{array}$ \\
\hline $\begin{array}{c}\text { Carter Creek and } \\
\text { Whitney Canyon } \\
\text { Fields. }\end{array}$ & $\begin{array}{l}\text { 'Wyoming } \\
\text { Overthrust Belt }\end{array}$ & $\begin{array}{l}\text { U. Mississippian } \\
\text { (Madison Group). }\end{array}$ & Dolomite & Harris et al. (1988); Sieverding and Harris (1991). \\
\hline Various Fields & $\begin{array}{l}\text { Central Kansas } \\
\text { Uplift (KS) }\end{array}$ & $\begin{array}{l}\text { Mississippian } \\
\text { (Miss. Lime and } \\
\text { "chat"). }\end{array}$ & $\begin{array}{l}\text { Limestone, } \\
\text { chert } \\
\text { residuum. }\end{array}$ & Wilson (1980a, b) \\
\hline $\begin{array}{l}\text { Crossfield, Harmatton } \\
\text { East, Harmattan } \\
\text { Elkton, Sundre, } \\
\text { westward Ho fields. }\end{array}$ & $\begin{array}{l}\text { Alberta Basin } \\
\text { (Canada) }\end{array}$ & $\begin{array}{l}\text { Mississippian } \\
\text { (Elkton Fm.) }\end{array}$ & Limestone & Martin (1964; 1966). \\
\hline $\begin{array}{l}\text { Various fields } \\
\text { (including those on } \\
\text { Horseshoe Atoll). }\end{array}$ & Midland Basin (TX) & $\begin{array}{c}\text { M. U. } \\
\text { Pennsylvanian } \\
\text { (Strawn, Canyon, } \\
\text { Cisco frns.) }\end{array}$ & $\begin{array}{l}\text { Limestone, } \\
\text { some } \\
\text { dolomite. }\end{array}$ & $\begin{array}{l}\text { Vest (1970); Reid and Mazzullo (1988); Reid et al., } \\
\text { (1990; 1991); Reid and Reid (1991). }\end{array}$ \\
\hline $\begin{array}{l}\text { Yates and Taylor Link } \\
\text { West fields (and } \\
\text { others). }\end{array}$ & $\begin{array}{l}\text { Central Basin } \\
\text { Platform (TX) }\end{array}$ & $\begin{array}{l}\text { U. Permian (San } \\
\text { Andres Fm.) }\end{array}$ & Dolomite & $\begin{array}{l}\text { Craig et al. (1986); Kerans and Parsley (1986); Craig } \\
\text { (1988). }\end{array}$ \\
\hline $\begin{array}{l}\text { Various fields } \\
\text { (including Ishimbay). }\end{array}$ & $\begin{array}{l}\text { Ural Foredeep } \\
\text { (CIS) }\end{array}$ & $\begin{array}{l}\text { Permian (various } \\
\text { units) }\end{array}$ & Dolomite & Maslov (1945); Masksimovich and Bykov (1982). \\
\hline $\begin{array}{l}\text { Malzen, Schonkirchen, } \\
\text { Reyersdorf fields. }\end{array}$ & $\begin{array}{l}\text { Vienna Basin } \\
\text { (Austria) }\end{array}$ & U. Triassic & Dolomite & Ladwein (1988). \\
\hline Nagylengyel Field & Hungary & $\begin{array}{l}\text { Triassic, some } \\
\text { Cretaceous }\end{array}$ & $\begin{array}{l}\text { Limestone, } \\
\text { some } \\
\text { dolomite. }\end{array}$ & Balint and Pach (1984). \\
\hline $\begin{array}{l}\text { Casablanca Field (and } \\
\text { others) }\end{array}$ & $\begin{array}{l}\text { Tarragonga Basin } \\
\text { (Spain) }\end{array}$ & U. Jurassic & $\begin{array}{l}\text { Limestone, } \\
\text { some } \\
\text { dolomite. }\end{array}$ & $\begin{array}{c}\text { Garcia-Sineriz et al. (1980); Watson (1982); Esteban } \\
\text { (1991). }\end{array}$ \\
\hline Unnamed & $\begin{array}{l}\text { Bresse Basin } \\
\text { (France) }\end{array}$ & Jurassic & Limestone & Fontaine et al. (1987). \\
\hline $\begin{array}{l}\text { Amposta Marino Field } \\
\text { (and others) }\end{array}$ & $\begin{array}{l}\text { Tarragonga Basin } \\
\text { (Spain) }\end{array}$ & $\begin{array}{l}\text { L. Cretaceous } \\
\text { (Montsia Fm.) }\end{array}$ & Limestone & $\begin{array}{l}\text { Garcia-Sineriz et al. (1980); Wigley et al. (1988); Bouvier } \\
\text { et al. (1990). }\end{array}$ \\
\hline Field " $A$ " & $\begin{array}{l}\text { Mediterranean } \\
\text { Basin }\end{array}$ & L. Cretaceous & Limestone & Fontaine et al. (1987). \\
\hline Stuart City Trend & $\begin{array}{l}\text { San Marcos Arch } \\
\text { and Gulf Coast } \\
\text { (TX) }\end{array}$ & $\begin{array}{l}\text { L. Cretaceous } \\
\text { (Edwards Fm.) }\end{array}$ & $\begin{array}{l}\text { Dolomite, } \\
\text { limestone }\end{array}$ & $\begin{array}{l}\text { Rose (1972); Bebout and Loucks (1974); Wilson (1980a, } \\
\text { b, 1985). }\end{array}$ \\
\hline North Field & Qatar (Persian Gulf) & $\begin{array}{l}\text { L. M. Cretaceous } \\
\text { (Mishni Fm.) }\end{array}$ & Limestone & Aves and Tappmeyer (1985). \\
\hline
\end{tabular}




\begin{tabular}{|c|c|c|c|c|}
\hline Field/Trend & Location & $\begin{array}{c}\text { Reservoir age } \\
\text { (unit) }\end{array}$ & $\begin{array}{l}\text { Reservoir } \\
\text { Lithology }\end{array}$ & Reference \\
\hline Golden Lane Trend & $\begin{array}{l}\text { Tampico } \\
\text { Embayment } \\
\text { (Mexico) }\end{array}$ & $\begin{array}{l}\text { M. Cretaceous (EI } \\
\text { Abra Fm.) }\end{array}$ & Limestone & $\begin{array}{l}\text { Viniegra and Castillo-Tejero (1970); Coogan et al. } \\
\text { (1972). }\end{array}$ \\
\hline $\begin{array}{l}\text { Campeche-Reforma } \\
\text { Trend }\end{array}$ & Mexico & $\begin{array}{l}\text { L.- U. Cretaceous } \\
\text { (U. Jurassic locally) }\end{array}$ & $\begin{array}{l}\text { Dolomite, } \\
\text { some } \\
\text { Limestone }\end{array}$ & Santiago-Acevedo, (1980). \\
\hline $\begin{array}{l}\text { BuHasa, Fahud, Fateh } \\
\text { and Natih Fields }\end{array}$ & $\begin{array}{l}\text { Saudia Arabia, } \\
\text { United Arab } \\
\text { Emirates (Persian } \\
\text { Gulf) }\end{array}$ & $\begin{array}{l}\text { Cretaceous (Wasia } \\
\text { Group) }\end{array}$ & Limestone & $\begin{array}{l}\text { Tschopp (1967); Twombley and Scott (1975); Wilson } \\
\text { (1980a,b; 1985); Harris and Frost (1984); Jordan et al., } \\
\text { (1985); Videtich et al., (1988). }\end{array}$ \\
\hline Rospo Mare Field & Italy & Cretaceous & Limestone & Dussert et al. (1988). \\
\hline Intisar " $D$ " & Sirte Basin (Libya) & $\begin{array}{l}\text { Paleocene (Intisar } \\
\text { Fm.) }\end{array}$ & Limestone & Brady et al. (1980). \\
\hline Kirkuk Field & Iraq & $\begin{array}{l}\text { Eocene-Oligocene } \\
\text { (Fars Fm.) }\end{array}$ & $\begin{array}{l}\text { Limestone- } \\
\text { dolomite }\end{array}$ & Daniel et al. (1988). \\
\hline Bombay High Field & India & Miocene & Limestone & Rao and Talukdar (1980). \\
\hline South Alamyshik Field & CIS & Paleogene & Limestone & Khutorov (1958). \\
\hline
\end{tabular}

\section{OVERVIEW OF PREVIOUS RESEARCH ON KARST RESERVOIRS}

Considerable insight into the geometries of karst systems in the Ellenburger Group was provided by the reassessment of Loucks and Anderson (1985). This model, based on detailed core and depositional systems analysis in the Puckett Field, demonstrated the potential for multiple stacked karst pay zones. This work was expanded by Loucks and Handford (1992) who documented karst processes in modern caves and compared it to an Ellenburger well from the Block 31 Field in Crane County, Texas. The ARCO well from the Block 31 Field shows multiple stacked karst cave systems indicating stacked zones of enhanced porosity and permeability zones (Figure $2 a$ and $2 b$ ).

In this model, the individual karst zones show a characteristic zonation with the bottom of a "breakdown breccia" zone delineating the floor of the paleokarst system. The "breakdown breccia" is largely sourced from the overlying roof and adjacent cavern sides during cavern collapse. It overlies or is deposited on what often appears to be an intact (unbrecciated) rock mass. In many systems, these apparently unbrecciated masses are actually large breccia blocks. The karst cavern is filled with breccia sourced from the roof and walls, along with allochthonous material transported into the system along fluvial/depositional channels. The roof of an individual cavern is delineated by a "crackle" or incipient breccia and the presence of an intact roof block. The potential complexity of this system, especially when observed in a small-diameter drill core, makes complete interpretation of the three dimensional geometry and extent of the system difficult to establish and predict.

Additional key elements of the Loucks and Anderson/Handford model include delineation of the various controls on karst processes (Figure 3) and the evolution of the cave system during burial (Figure 4). The evolution of the system during burial is a critical phase because of the potential for authigenic cements to degrade the karst breccia porosity and permeability. Most importantly, these papers recognized the importance of tectonic precursor fabrics that nucleate dissolution features, and the 
potential importance of karst-related processes being overprinted and connected by tectonic deformation after karstification.

Following the seminal work of Loucks and Anderson (1985), Kerans $(1988 ; 1990)$ outlined the regional extent of the depositional systems and overprinting karstification processes affecting the Ellenburger Group reservoirs in West Texas (Figure 5), and suggested several exploration and field development strategies based on the regional model. Kerans recognized a dominant karst event that corresponded to the major sea level fall in Middle Ordovician time. As a result, the Ellenburger Group shows a primary karstification event at the top of the section.

Work by Kerans demonstrated the pervasive nature of the karstification process in the Ellenburger Group of West Texas and outlined the potential for recompletions in many fields where only the uppermost karst breccia zone was perforated. In Andector, Kerans demonstrated that most of the production came from only the uppermost karst zone and that considerable potential for bypassed pay probably exists in deeper zones (Figure 6). This model and independent observations of adjacent fields, led Phillips to drill and test the Phillips South Fault Block Unit (SFBU) \#4-62 which will be discussed in greater detail later in this text.

\section{OVERVIEW OF ANDECTOR FIELD AND ELLENBURGER GROUP}

\section{ANDECTOR FTELD OVERVIEW:}

The fracture analysis described in this research project was performed for the Phillips South Fault Block (SFBU) \#4-62 well located in Andector Field, Northwest Ector County, Texas (See Figure 7 for structure map of field). The overall structure of the field is a NW-trending anticline with a major NW-trending fault along the northeast flank of the anticline. The two culminations of the anticline were created by a later NE-trending fault that bifurcates the structure. A recent 3D seismic survey of the field reveals additional faulting along these two dominant trends ranging down to a subseismic scale. The north fault block of Andector Field was discovered in 1946 and the south fault block was discovered in September, 1947. Since the initial discovery in the Ellenburger Group carbonates, approximately 150 wells have been drilled that penetrate this horizon. Additional wells have been drilled to exploit shallower reservoir horizons. It was recognized early that Andector shares a common water drive - aquifer with several adjacent Ellenburger fields: TXL, Embar, Martin and Wheeler (Moore et al., 1952). Earlier production from TXI field (to the southwest) reduced the initial Andector reservoir pressure on discovery approximately $800 \mathrm{psi}$ (Figure 8). Re-injection of produced water has attempted to minimize the pressure loss from the common aquifer. The maximum reservoir thickness is approximately 700 feet, the productive interval is approximately 325 feet thick, average reservoir porosity is $3.8 \%$ (from core) . As of January, 1998, the field had produced 116.2 million barrels of oil ( $44^{\circ}$ API, post 1958, production data were not reported for the first ten years of production), making it the volumetrically largest Ellenburger producing field in West Texas.

\section{ELLENBURGER GROUP:}

Regionally, the Ellenburger Group has been separated into three formations: the Tanyard, Gorman and Honeycut formations, from bottom to top, respectively (Kerans, 1988). Unfortunately, due to intense dolomitization and the absence of chronostratigraphic control, most workers have attempted to subdivide the Ellenburger using lithofacies assemblages. Use of insoluble residue methods (e.g. Barnes 
et al., 1959) to identify correlative assemblages across the region have been met with equivocal success. More recent recognition of the pervasive karst fabrics and their depositional importance has further minimized the importance of regional stratigraphic relationships in favor of lithofacies assemblage analysis.

The Ellenburger system lies unconformably on the basement complex and/or a coarse-grained sandstone (Bliss equivalent?). The basement rocks in the field are composed of metamorphic rocks, primarily arkosic sandstones and a medium-grained muscovite schist. Petrographic analysis suggests that it represents a metasedimentary sequence. Increased alteration of hornblende and biotite toward the overlying contact with the Ellenburger indicates the presence of an erosional contact. Angular discordance between the consistent NW-striking, SE-dipping, metamorphic foliation observed throughout the South Fault Block \#4-62 well cored interval and the overlying carbonate rocks support this interpretation.

In Andector Field, the Ellenburger, as observed in the South Fault Block \#4-62 well that cored through the entire Ellenburger, is composed of shallowing upwards, peritidal carbonate cycles ranging in thickness from 8-18 feet. There are three general lithofacies found developed in three depositional cycles. They are (from greatest well depth to shallowest): 1) dolomitized grainstones; 2) dolomitized laminated wackestones to packstones; and 3) dolomitized laminated to massive mudstones. Nearly all primary sedimentary features have been obliterated by intense dolomitization.

Dolomitized grainstones rarely exceed three feet in thickness and are developed at the base of shallowing-upwards cycles. In this lithology, fracture porosity is the most important type and fractures are generally 1) cemented by dolomite; and/or 2) partially occluded by dolomite and pyrite. Most fractures are hydrocarbon stained.

Dolomitized laminated wackestone to packstone lithofacies represents the most dominant lithofacies and was interpreted to have been deposited in a tidal flat (peritidal) environment.

In the same well, the dolomitized laminated to massive mudstones are volumetrically minor and is interpreted to have been formed in a evaporative pond/lagoonal environment. This facies is found in the upper portion of the dolomitized wackestones to packstones.

In the recent interpretations of the karsted Ellenburger, there are several distinct reservoir lithofacies that correspond to the karst system. This karst system overprints the primary (pre-karst) lithofacies assemblages: In general, there are four types of lithofacies. Figure 9 outlines the different characteristics of these lithofacies. They include: 1) fracture breccia,; 2) mosaic breccia; 3) chaotic breccia (siliciclastic matrix supported); and 4) chaotic breccia (carbonate clast-supported). In most of the work that has been performed on the Ellenburger, (e.g. Kerans, 1988; 1990; Loucks and Anderson, 1985; Loucks and Handford, 1991; Loucks and Mescher, 1997), little effort has been expended toward understanding the relative importance of tectonic fractures that overprint the karst fracture system. Instead, the majority of effort has been expended towards documenting the characteristics of the karst system. In fact, the only criterion established for recognition of tectonic fracture overprint is the observation that tectonic fractures crosscut the late "saddle dolomite" diagenetic phase (Kerans, 1990). We have chosen to supplement this characterization scheme by incorporating tectonic fractures and identifying criteria to distinguish between the two sets. Most importantly, we have outlined the significance of the two fracture sets to exploration programs in the region. These implications are also valid for the abundant composite (combination of karst and tectonic) reservoirs found throughout the world. 


\section{- ARCO BLOCK 31 UNIT "W" \#1 \\ CRANE COUNTY, TEXAS}

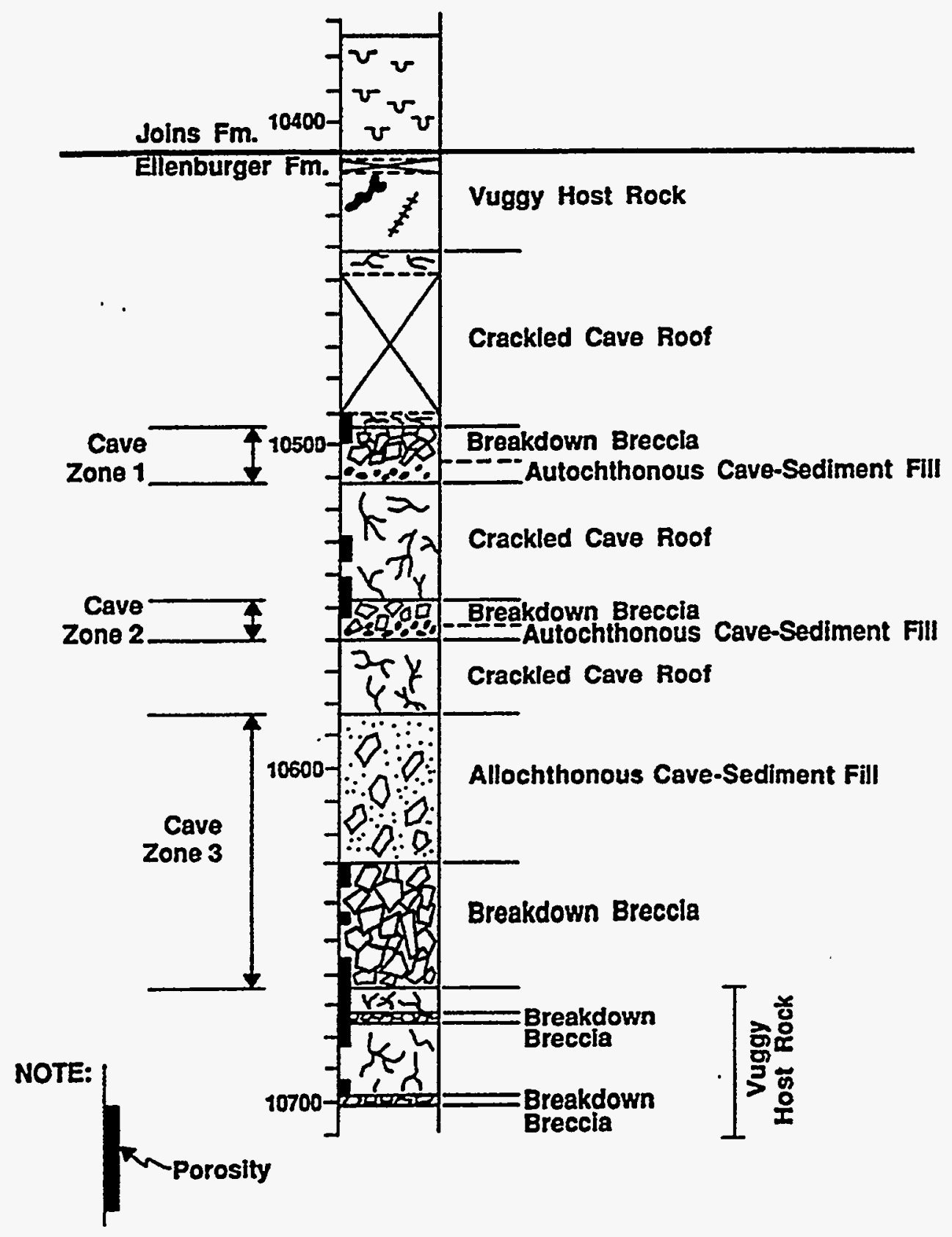

Summary of cave zone fabrics

Figure 2a: Core schematic for the Upper Ellenburger in the ARCO Block 31 "W" \#1 in Crane Coumty, Texas. Adapted after Loucks and Anderson (1985). 


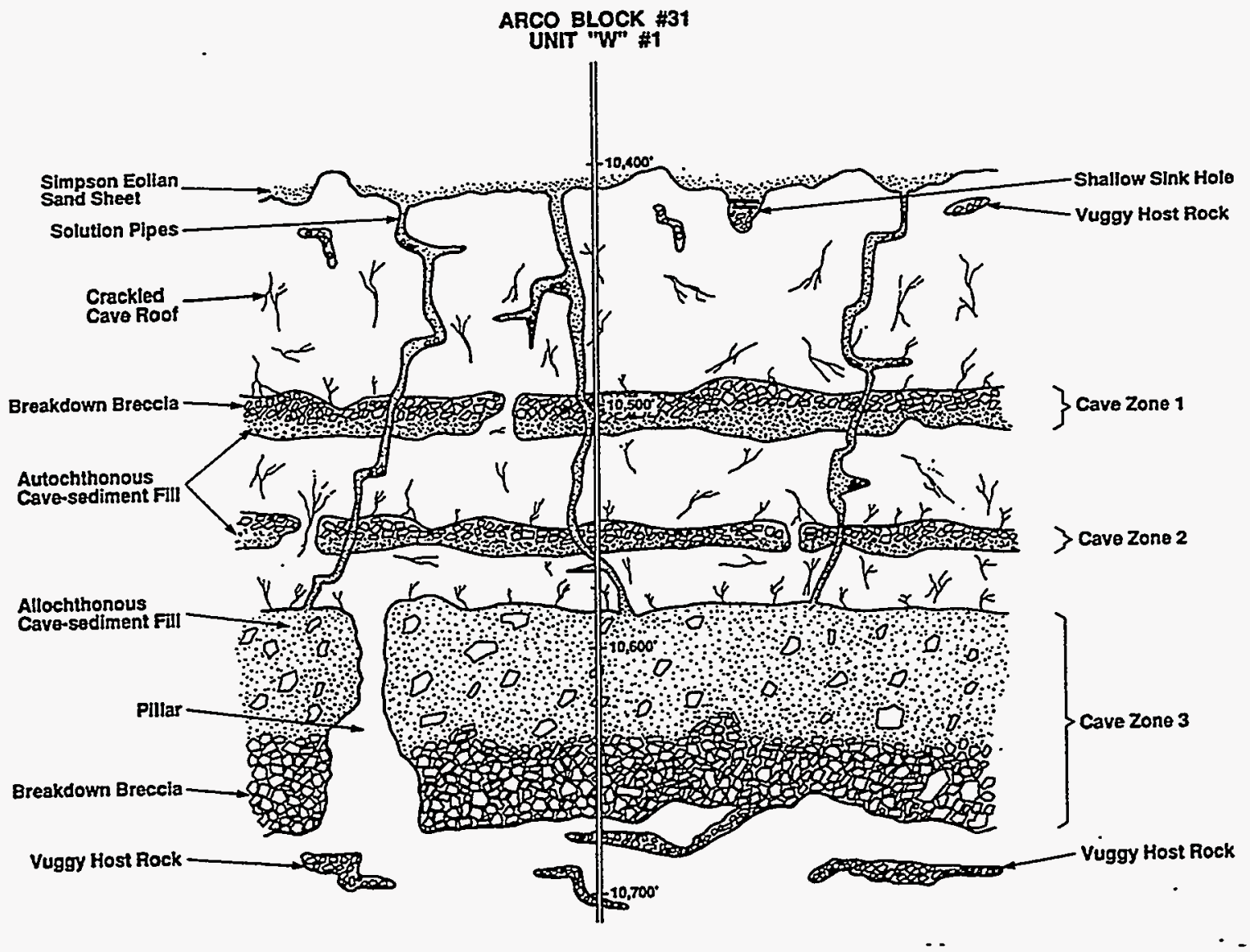

Figure 2B: Interpreted karst cave depositional system for the ARCO Block 31 Unit "W" \#1 well, Crane County, Texas. Adapted from Loucks and Anderson (1985).

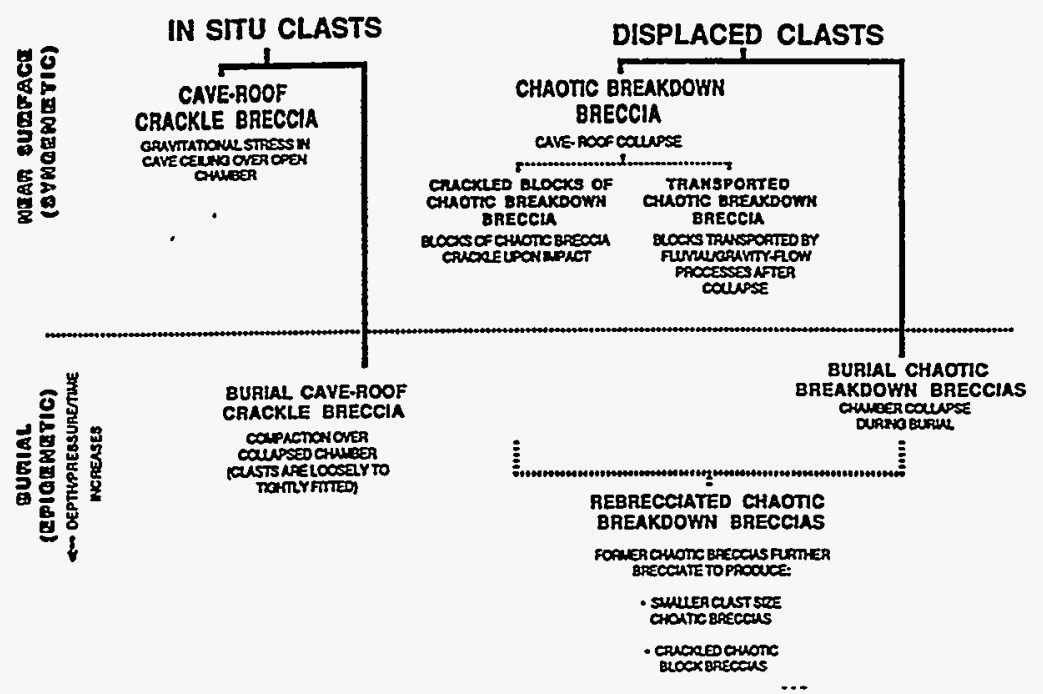

Figure 3: Cave-related brecciation processes. Flow diagram outlines typical processes, products and subsurface environment of karst system. After Loucks and Anderson (1985). 


\section{CAVE-RELATED BRECCIATION PROCESSES}

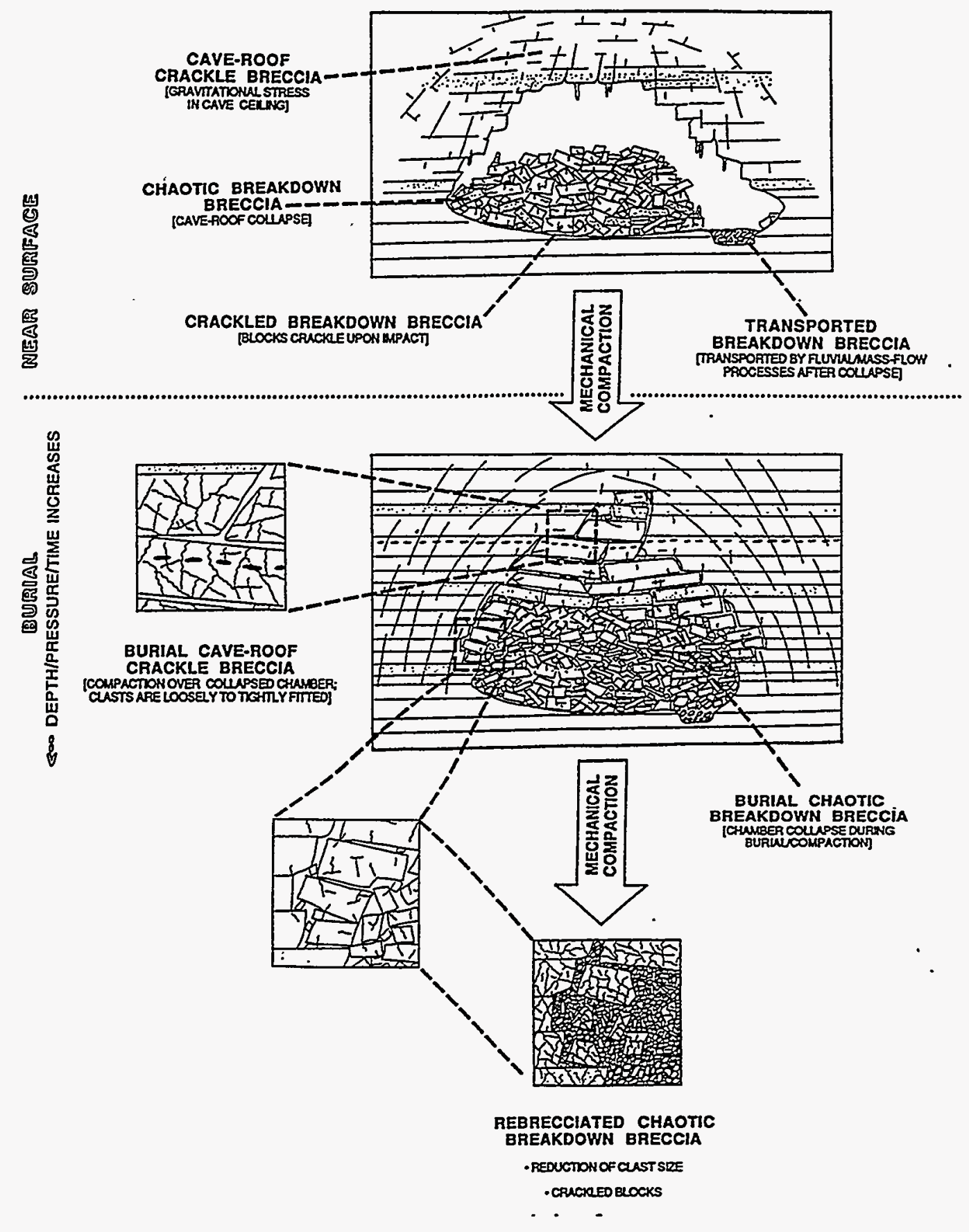

Figure 4: Schematic diagram illustrating effect of burial on karst-related dissolution and brecciation processes. Modified after Loucks and Anderson (1985). 


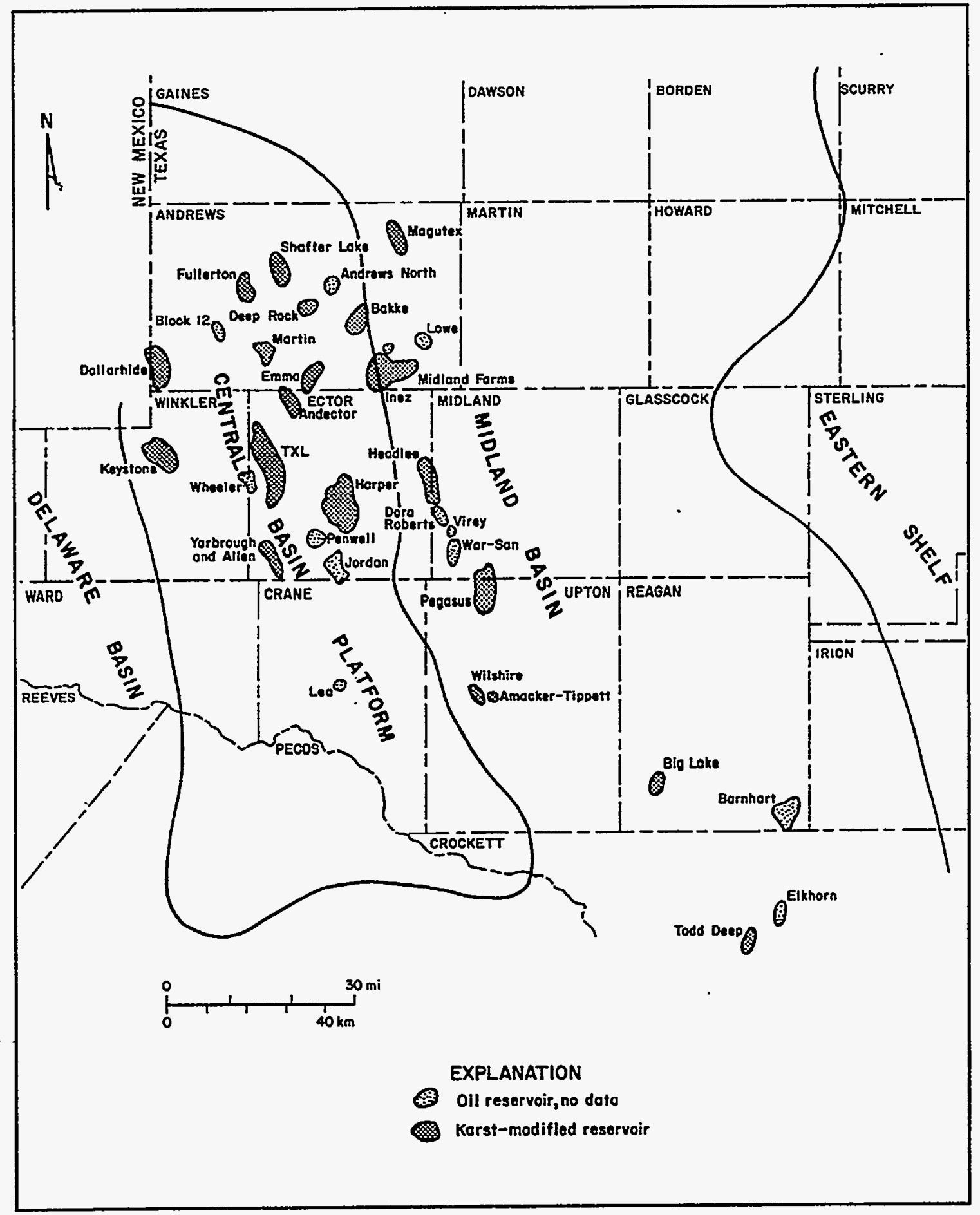

Figure 5: Regional distribution of karst-modified Ellenburger oil reservoirs that have produced $>10 \mathrm{MMBL}$ cumulative production in West Texas. Note that many smaller karsted reservoirs are likely present but little work has been done to date to fully characterize and document the extent of karst-related processes. From Kerans (1988). 


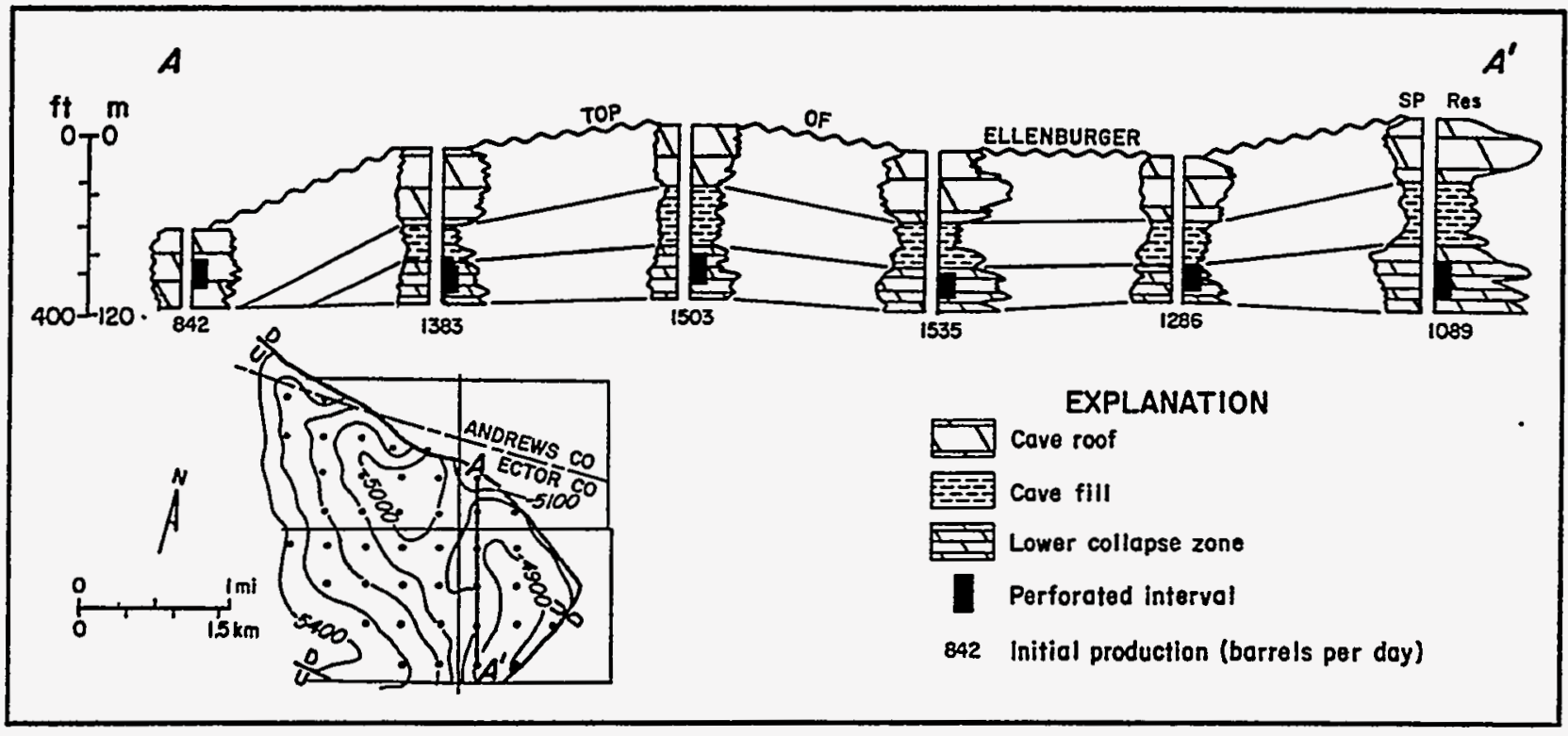

Figure 6: Cross-section from North Fault Block, Andector Field. Ellenburger Reservoir. Note apparent topographic relief on top Ellenburger surface based on lower collapse zone base reference datum (assumed horizontal). From Kerans (1990). 


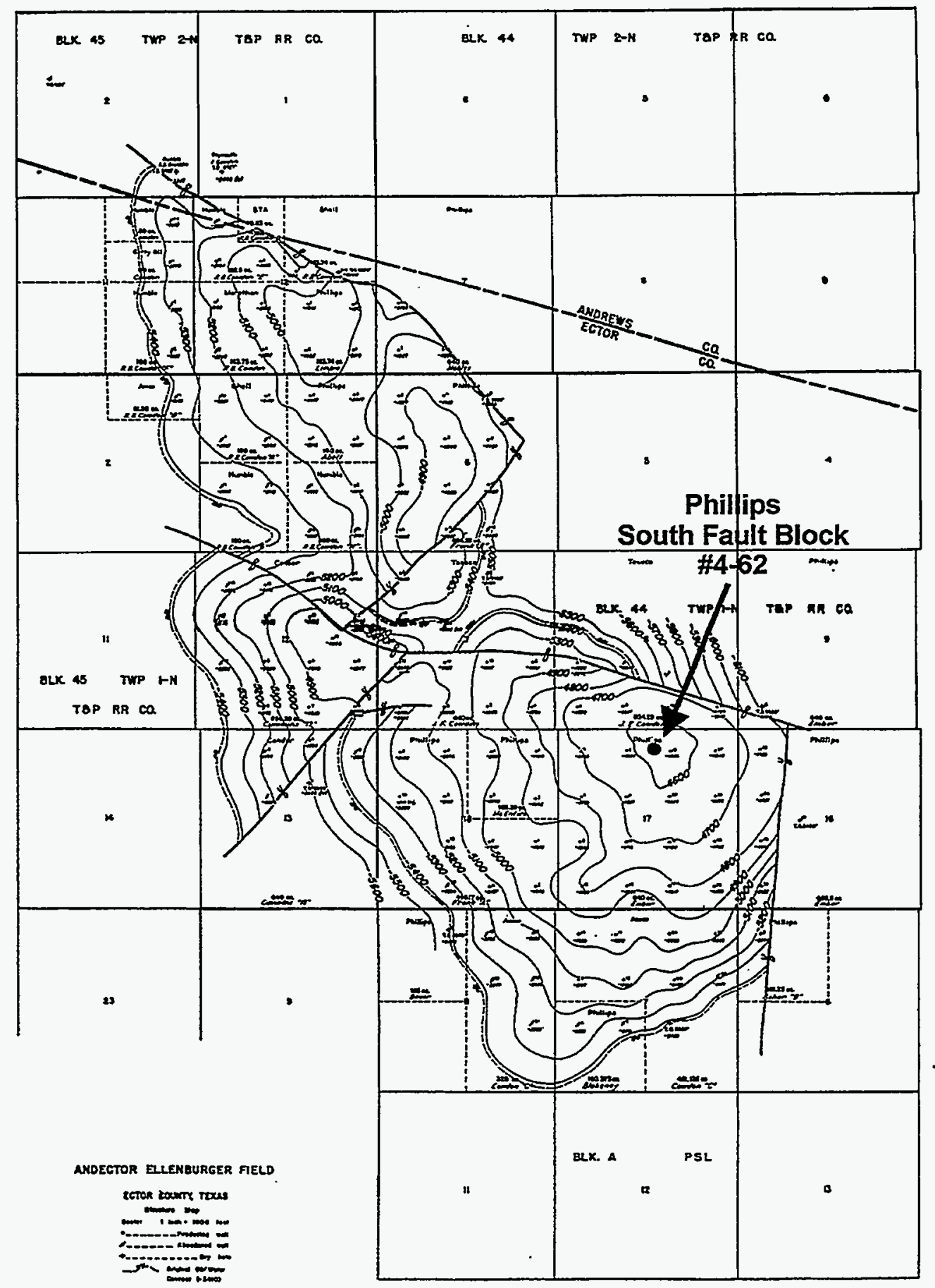

Figure 7: Andector Field structure map on top Ellenburger. Map does not incorporate smallscale faulting or well penetrations that produce from shallower pay zones. Modified after Phillips Company reports. South Fault Block \#4-62 has had oriented core taken through entire Ellenburger. See text for discussion and synthesis. 


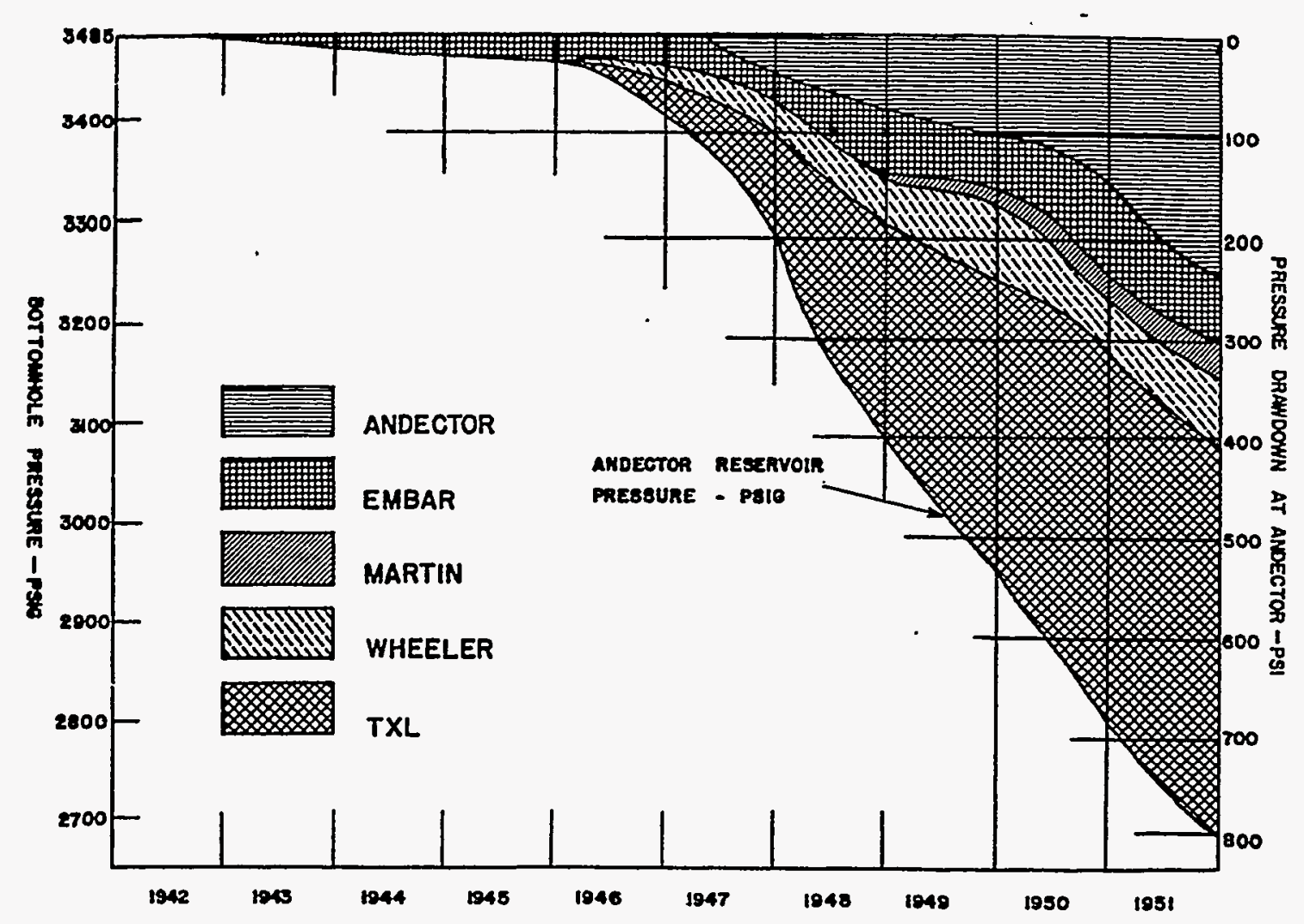

Figure 8: Effect on Andector reservoir pressure caused by production from adjacent Ellenburger fields sharing the common regional water-drive. Note that as of 1952 , Andector pressure had been depleted nearly 800 psi from initial regional pressure (shown by TXL discovery well-1942). After Moore et al. (1952). 


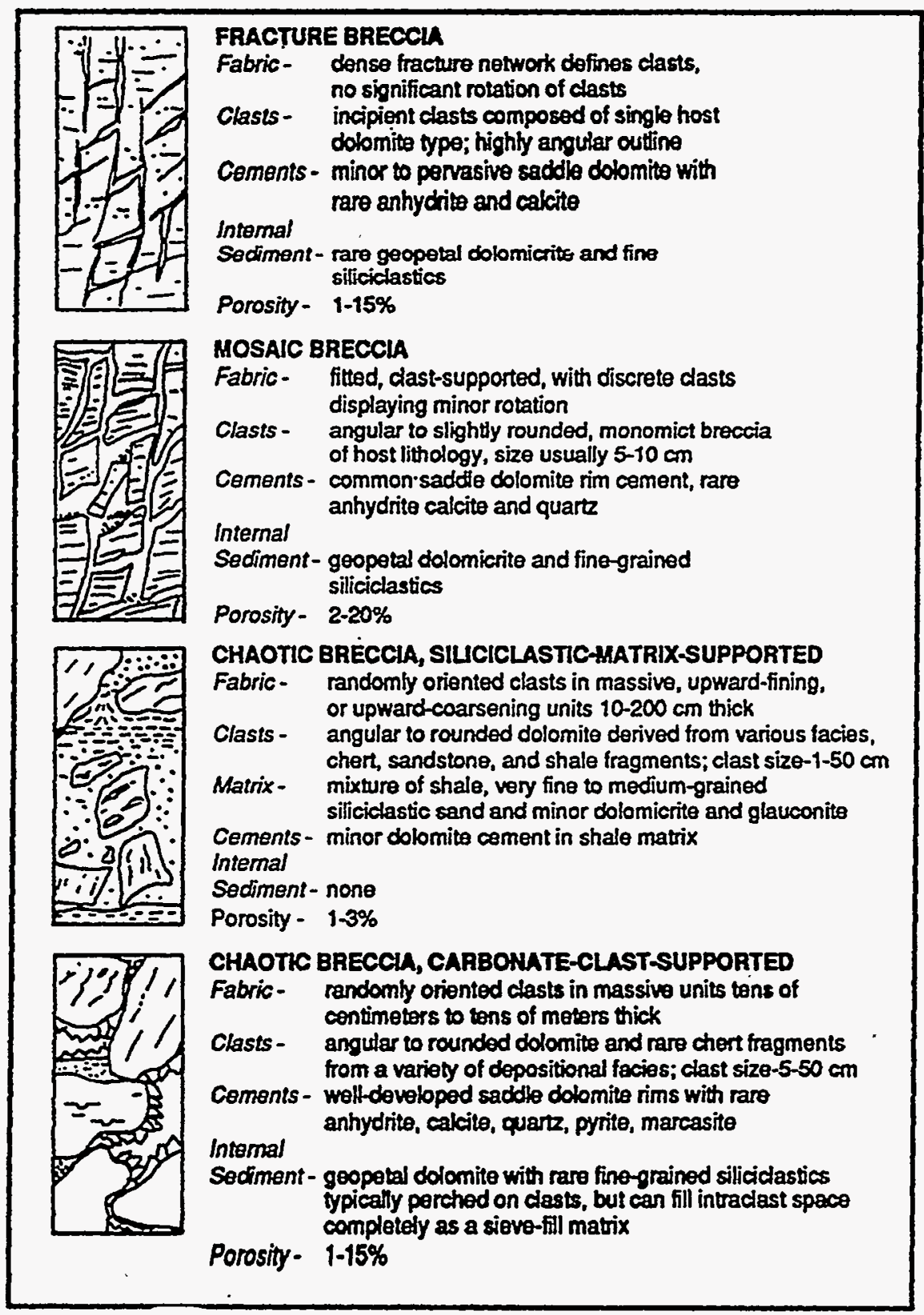

Figure 9: Typical breccia types found in Ellenburger karsted reservoirs. Note absence of tectonic fracture elements and the difficulty of distinguishing between "fracture breccias" formed by karst and tectonic processes. Modified after Kerans (1990). 


\section{FRACTURE GENESIS DISCRIMINATION CRITERIA:}

Our approach to distinguishing between karst and tectonic fracture systems relies heavily on placing the reservoir into a regional depositional, diagenetic and tectonic framework (Hoak et al., 1998). It requires the integration of these different aspects of the geologic history in order to refine the potential interpretations of observed features. We have outlined the key points of each fracture system. It should be emphasized that these characteristics are not restricted to the fractured carbonates of the Ellenburger Group and, most importantly, that local exceptions to these generalizations may be found. In identifying these exceptions and the circumstances that created them, significant insight is gained into the evolution of the reservoir system. Many of the differences between the two sets are related to the stress system present at the time of fracture formation. In most karst systems, fracturing occurs at shallow structural levels under conditions of near-hydrostatic stress. In contrast, most tectonic fractures occur during active deformation, usually in a highly anisotropic stress system. Complicating the analysis is the observation that many karst systems appear to preferentially occur along deeper (e.g. basement) structural anisotropies. This creates the appearance of a highly ordered system in the karst systems. In such scenarios, understanding the deformation style and anisotropy in the basement and underlying systems because a critical requirement for interpreting the karst and tectonic fracture sets that formed later. In addition, when karst systems are buried, some cement phases that infill open fractures during burial may suggest higher temperature processes. This underscores the importance of fully integrating fracture observations, fracture characteristics, regional diagenetic constraints, and geochemistry.

\section{KARST FRACTURES AND RELATED BRECCIAS:}

- Generally restricted to carbonate rocks

- Preferentially developed in fine-grained dolomites and limestones

- Non-systematic, often radial pattern in plan view (low confining stress)

- Concentrated in discrete zones (vertically segregated)

- Often follow rectilinear pattern in plan view (if pre-existing anisotropy present)

- Appear to show a characterizable sequence of formation (e.g. Kerans, 1990)

- This sequence can be readily identified in core.

- Fractures often possess horizontal orientation.

- Evidence of other dissolution features

- May contain paleosols and similar near-surface deposits.

- Often show horizontal (paleo-water table) sedimentation infill

- Few fractures will show fibrous morphology indicating syndilational cementation

- Isotopic signatures of synkarst cements reflect meteoric water with limited mixing

- Breccia zones frequently parallel bedding and/or distinct diagenetic zones in the matrix.

- Associated stylolites will tend to be horizontal to sub-horizontal.

- Overlying and underlying lithologies (especially carbonates) will show similar fractures.

\section{TECTONIC FRACTURES AND RELATED TECTONIC BRECCIAS:}

- Found in all lithologies.

- Generally will crosscut cave fill sediment and breccia deposits

- Will crosscut last cement phase in rock prior to tectonism

- Mineral infill may be syntectonic and fibrous.

- Possess a systematic orientation controlled by regional and local stress regime

- Rarely horizontal in orientation.

- Isotopic signatures often reflect deeper, hotter basinal fluids (e.g. basinal brines) 
- Distinctive surface ornamentation

- Associated minor structures are systematic.

- Associated stylolites will tend to be vertical to steeply-dipping

- Generally can be associated with adjacent folds and/or faults

- Breccia zones frequently crosscut bedding

- Breccias show a progressive grain-size reduction via cataclasis into the zone.

- Overlying and underlying lithologies (especially siliciclastics) will show similar fractures.

Despite these generalized criteria, many fractures will remain ambiguous, especially in unoriented cores, and in regions where local subsurface depositional, diagenetic and structural complexity are poorly constrained. In such circumstances, it is best to develop the two end-member categories of 1) tectonic; and 2) karst; and create another category of 3) unknown to encompass those fractures and reservoir intervals that cannot be easily understood. In many cases, additional data will be found that will permit many of the unknown fractures to be classified based on new diagenetic analyses, depositional systems models, or isotopic analysis of fracture cements.

We have documented the typical appearance of the different types of fractures in the accompanying photos. In many cases, the interpretation is unequivocal and follows the classic descriptions of Loucks and Handford (1992) and Kerans (1990).

\section{Karst Fractures:}

Figure 10 shows examples of karst-related fracturing. The photo is taken from the AnschutzFasken \#16-2. The photo illustrates a typical karst fracture breccia with dolomite cement enclosing the brecciated clasts. The photo also demonstrates the range of clast sizes that might be expected.

Figure 11 illustrates a more intensely brecciated interval of the same well. This photo shows considerable clast rotation and is intensely cemented by dolomite cement.

Figure 12 shows a typical incipient fracture breccia taken from below the previous two photos. Note the intensely brecciated zone at the upper right of the photo and its similarity to the previous two photos. The horizontal fractures show similar dolomite cement to the near-vertical fractures and indicate the likelihood that these fractures are part of the incipient "crackle breccia" that typically underlies (floor) and overlies (roof) a karst breccia horizon. In this case, it represents both.

Figure 13 represents an example of the effect of burial on a karst (?) breccia block. The exact origin of these fractures is equivocal. It appears that dissolution along the karst (?) fracture planes has been partially healed by precipitation of dolomite cements. During burial, the open fractures and related vugs did not close and oil was able to migrate through the system.

\section{Tectonic Fractures:}

Figure 14 illustrates unequivocal tectonic fractures cemented by dolomite that crosscut a karst breccia zone and related siliciclastic-dominated breccia. Photo from the Humble-Yarbrouogh Allen \#22.

Figure 15 shows unequivocal tectonic fractures crosscutting sandstones of the Simpson Group. This photo, from the Gulf Oil-A.M. State \#1-E, shows the importance of examining adjacent lithologies to assess fracture morphologies, mineralization, and the continuity of these observed characteristics into the suspected karst zone. The ability to look at overlying and underlying strata represent one of the best methods to distinguish the intensity of tectonic fracturing. 


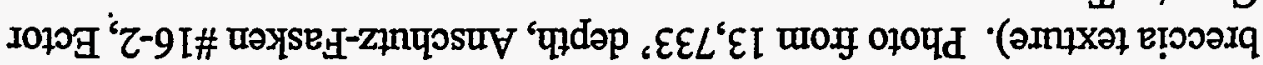

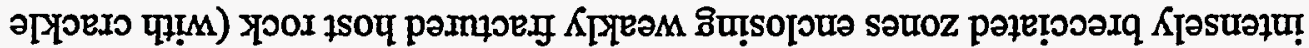

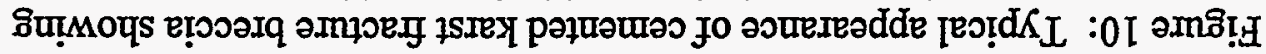

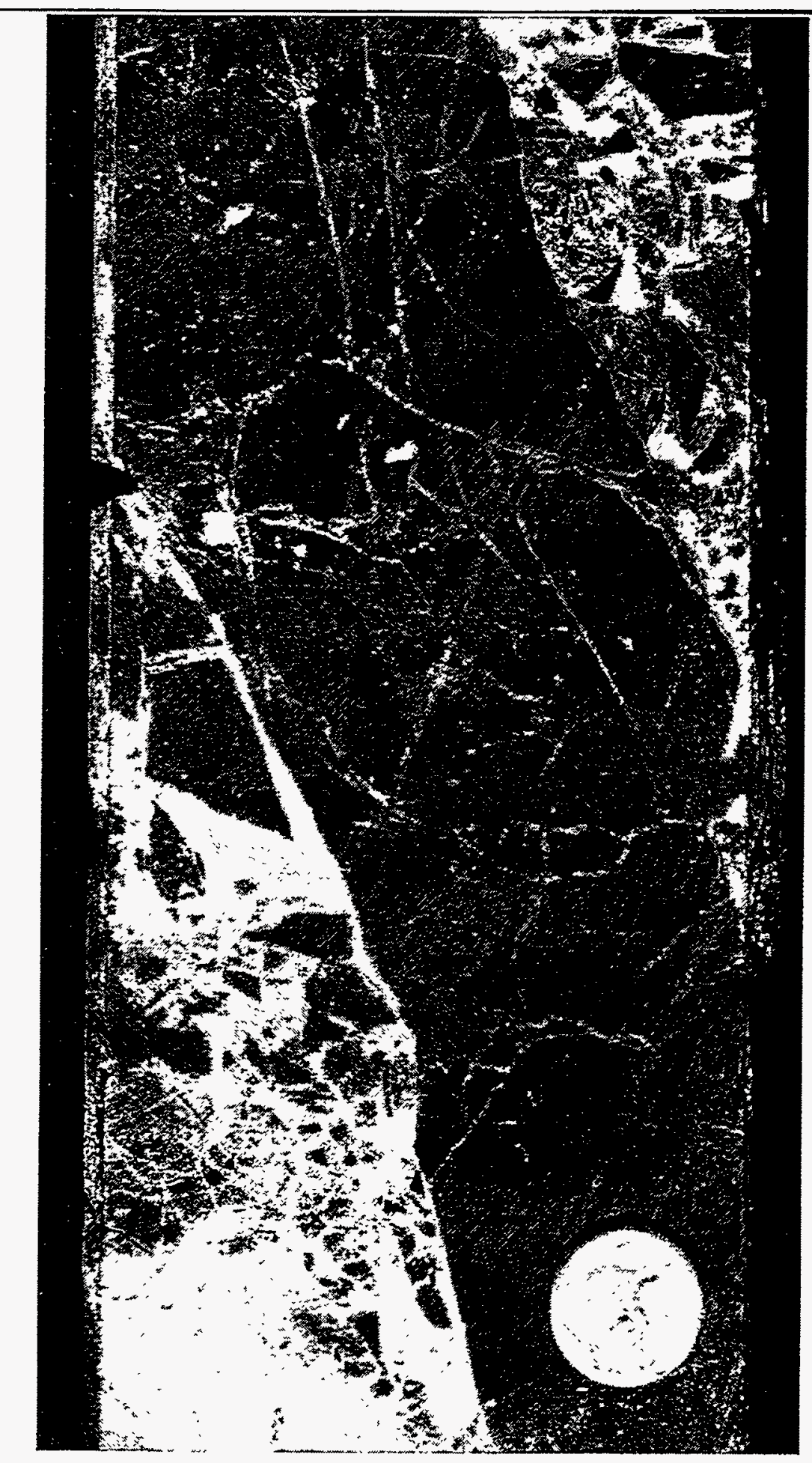




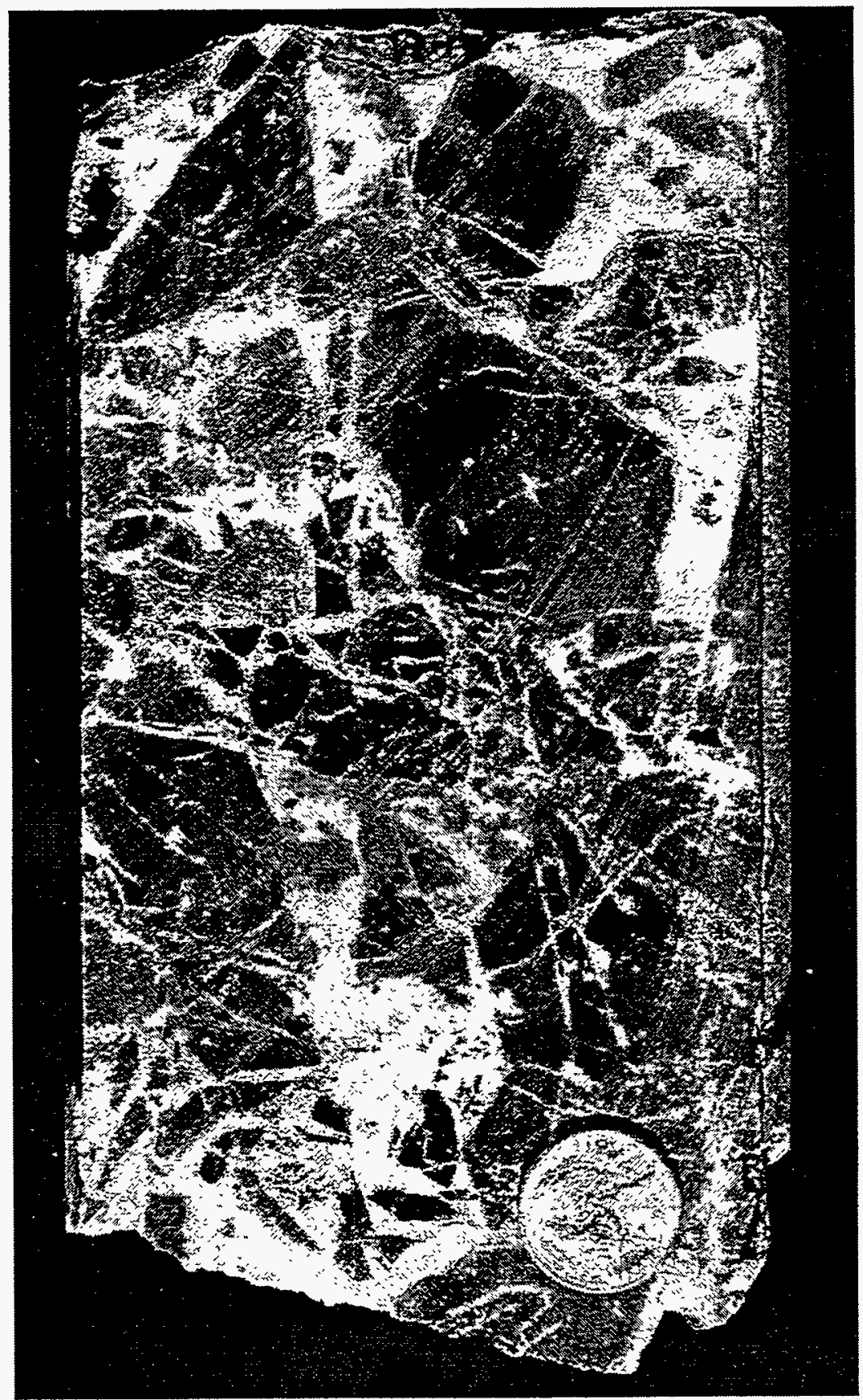

Figure 11: Typical appearance of cemented karst fracture breccia showing intensely brecciated zones cemented with dolomite. Photo from 13,721' depth, Anschutz-Fasken \#16-2, Ector County, Texas. 


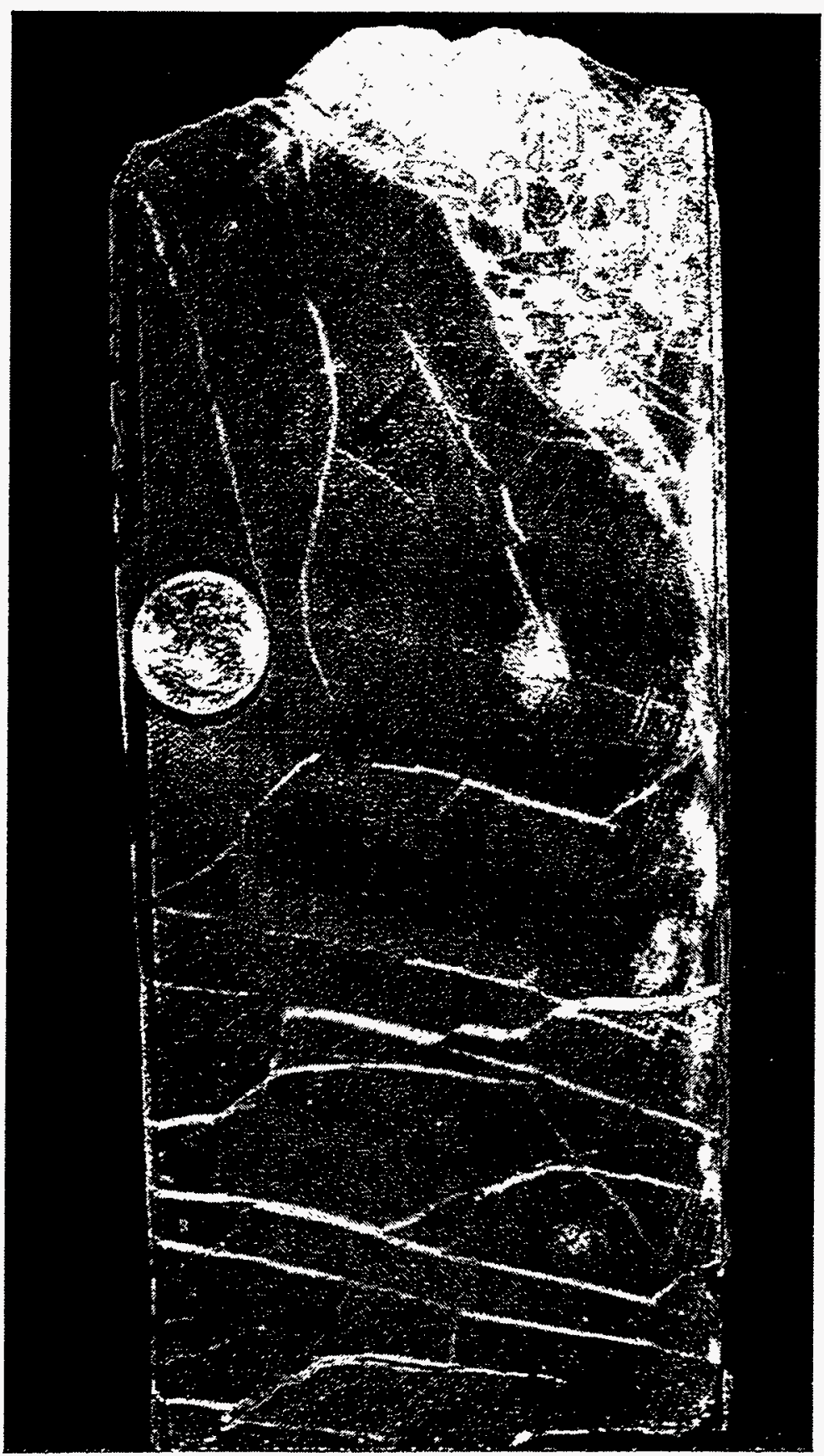

Figure 12: Typical appearance of incipient karst fracture breccia showing intensely brecciated zones parallel to fractures delineating crackle breccia texture in matrix block. Horizontal dolomite-cemented fractures and adjacent vertical fractures possess similar fracture infill to that found in intensely brecciated zone. This similarity strongly suggests karst origin. Also, no fractures crosscut the intense breccia in the upper right of the photo. Photo from 13,667' depth, Anschutz-Fasken \#16-2, Ector County, Texas. 


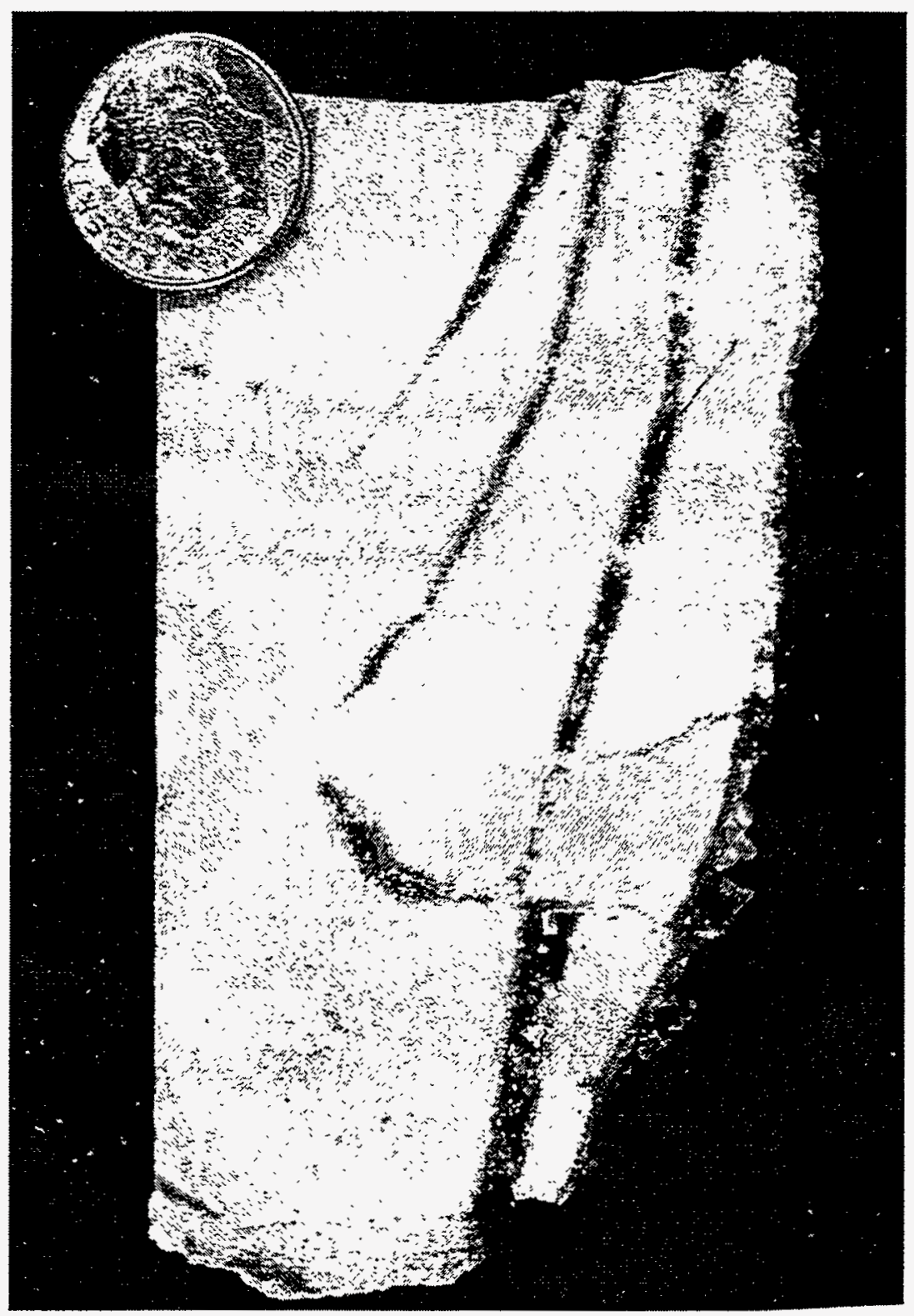

Figure 13: Oil-stained baroque dolomite crystals lining vertical and subhorizontal fractures. Fractures are thought to be of karst origin due to presence of both horizontal and vertical sets. Fractures must have remained opened during burial diagenesis as evidenced by coarse crystalline dolomite (baroque) cements and oil-staining. Photo from 13,080' depth, Cities Service Company- Foster \#1, Ector County, Texas. 


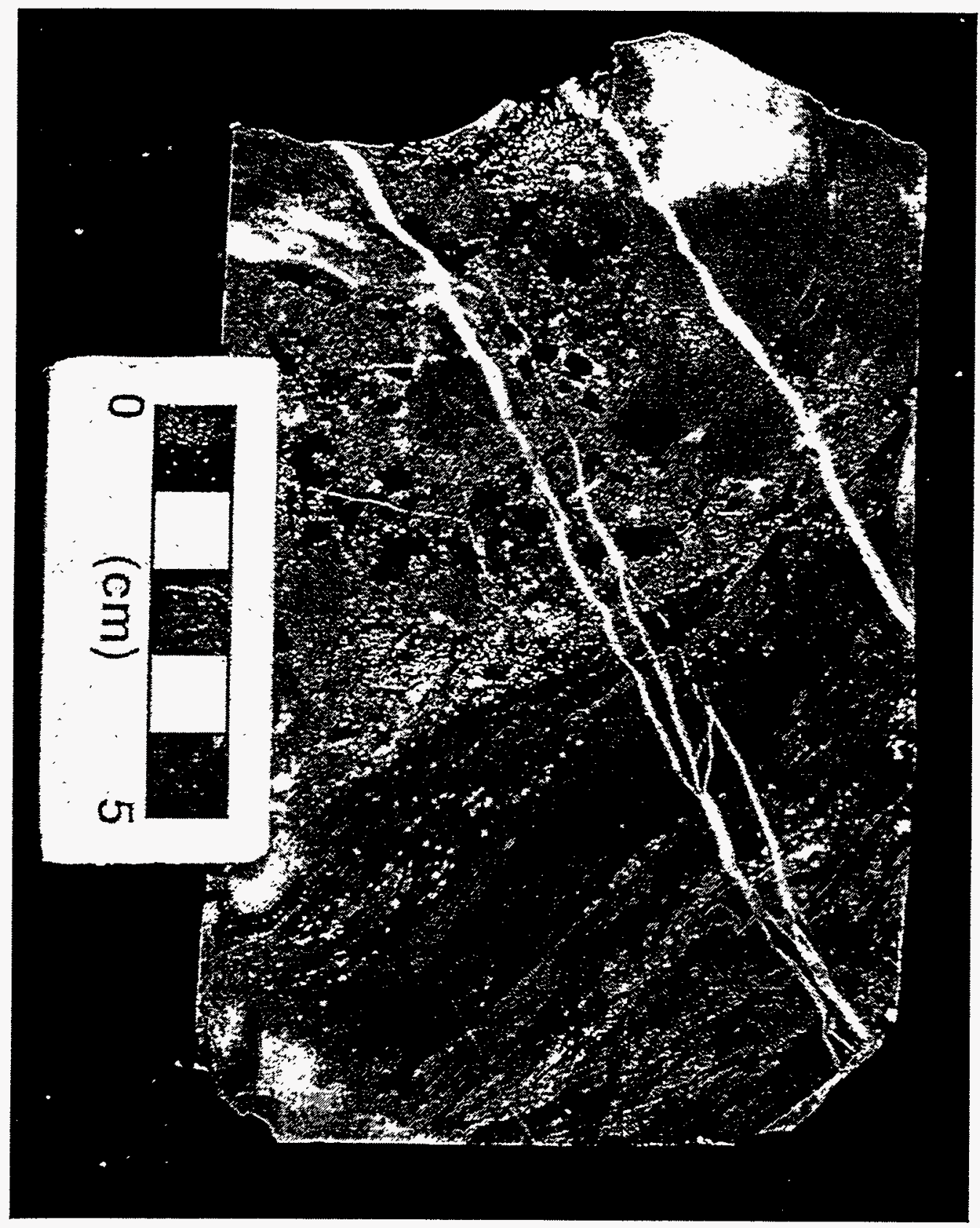

Figure 14: Unequivocal tectonic fractures mineralized with coarse dolomite crosscutting karst breccia zone and related siliciclastic-dominated sediments. Photo from 10,554' depth, HumbleYarbrough Allen \#22, Ector County, Texas. 


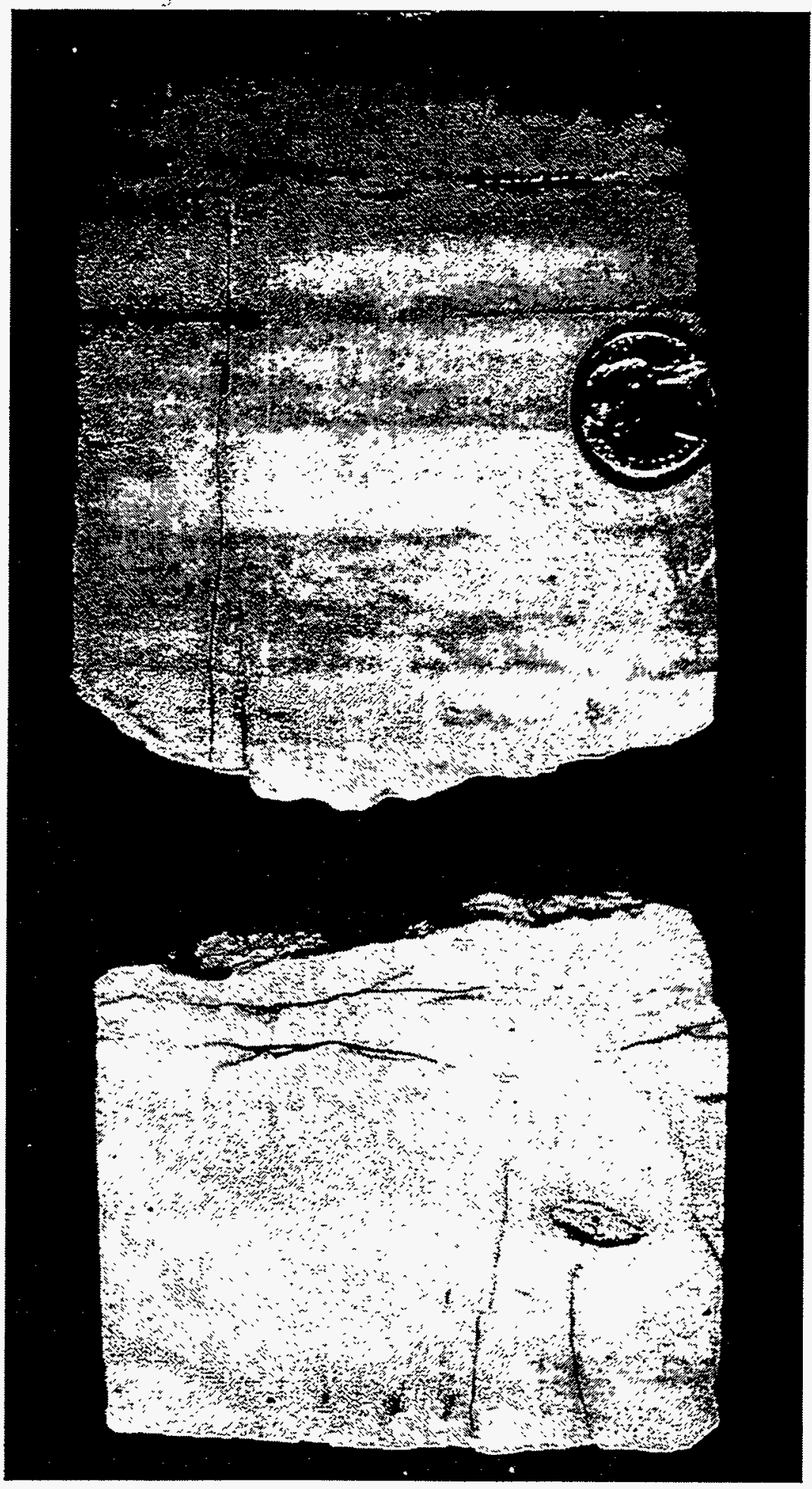

Figure 15: Unequivocal, unmineralized, oil-stained, tectonic fractures crosscutting Simpson Group Sandstones that overlie the Ellenburger Group. Note rusty-weathering and apparent unmineralized character. Presence of tectonic fractures lacking mineralization and possessing rusty-weathering in overlying siliciclastics suggests similar morphology fractures may be present in Ellenburger. Photo from 12,481' depth, Gulf Oil-A.M. State \#1-E. 


\section{REGIONAL DIAGENETIC SEQUENCE}

As mentioned earlier, it is critical to establish a diagenetic framework for the reservoir rocks and demonstrate the relationship between the diagenetic sequence observed in the host rock, and in the tectonic and karst fractures that crosscut the undeformed protolith.

In the Ellenburger, a regional diagenetic sequence has been established using published literature and proprietary Phillips company reports (Prezbindowski, 1989; Kupecz, 1989. Kerans, 1990; Prezbindowski, 1991; see Figure 16 for simplified summary diagram of Kerans). We have attempted to reconcile these different' sequences into a unified sequence that retains local variations within the context of observed regional characteristics. The sequence is broken down into three primary events that correspond to periods before, synchronous and after the Middle Ordovician karstification event. It is important to emphasize that the maximum burial temperature (Approximately 110 degrees Celsius, using Lopatin modeling results and geothermal gradient data from Katz et al., 1994; consistent with stable isotope thermometry results of this study and Kupecz, 1989) was achieved in the Late Pennsylvanian-Early Permian during the period of active tectonic deformation and regional shortening in the basin (See Figure 17 for burial history plot).

The sequence we have established is as follows:

\section{In the pre-karst phase (Ordovician)}

- Carbonate deposition

- $\quad$ Chert (Q1)

- Dolomite replacement of original carbonate protolith (ED1)

${ }^{87} \mathrm{Sr} /{ }^{86} \mathrm{Sr}$ and $\delta^{13} \mathrm{C}$ appear rock buffered, low overall strontium concentration, no strontium concentration difference between populations.

Depleted $\delta^{18} \mathrm{O}(-2.4$ to $-8.8 \%$ per $\mathrm{ml} / \mathrm{PDB})$ relative to seawater, non-karst $\delta^{18} \mathrm{O}$ ranges -2.3 to -5.1 , karsted $\delta^{18} \mathrm{O}$ ranges from $-2.4-$ to -8.7 , heaviest $\delta^{18} \mathrm{O}$ are fine crystalline and non-luminescent, $\delta^{18} \mathrm{O}$ depleted are coarse crystalline and orange-luminescent. Karst breccias tend to be depleted in $\delta^{18} \mathrm{O}$.

\section{Karst event (Middle Ordovician)}

Global sea level fall, emergence of upper Ellenburger, formation of karst breccias and related features, overall karstification of Ellenburger system.

\section{Post-karstification phase}

- Dolomite/chert cementation of vugs and early fractures

- Barite (B1):

Local precipitation of barite cement in upper zone, buried collapse features and in karst fractures. 
- Pyrite (P1?):

Local pyrite precipitation in upper zone associated with dissolution of anhydrite/barite and subsequent sulfate reduction. Exact timing is somewhat equivocal based on thin-section petrography, may be late phase infill of pre-existing voids.

- Dolomite (Matrix Cement-LD1)

Coarse to very coarse crystals, approaches stochiometry $\left(50.5 \%\right.$ mole $\left.\mathrm{CaCO}_{3}\right)$

- Chert (Matrix Cement-Q2)

Crosscut by veins of megaquartz followed by LD2 cement and LD2 veins

- Microfracturing/dissolution of chert

- Chert (Fracture Cement- Q3)

Observed only in fractures and veins that crosscut massively crystallized dolomite, exact timing ambiguous.

- Dolomite (Karst/Tectonic Fracture and Matrix Cement-LD2)

Patches of near stochiometric $\left(50.8 \%\right.$ mole $\left.\mathrm{CaCO}_{3}\right)$ in overall Ca-rich $\left(52.2 \% \mathrm{CaCO}_{3}\right)$ matrix, Fluid inclusions interpreted as cogenetic with Q3 megaquartz extrapolate to 60-110 degrees

Celsius, orange luminescent fracture infill and karst clast outlining cement, medium to VCC (1003500 microns).

- Megaquartz (Tectonic Fracture and Matrix Cement-Q3)

Fluid inclusions interpreted as cogenetic with LD2 dolomite show 85 degrees +-6 degrees Celsius, intergranular and vug filling cement occurs as pore-filling with LD2 dolomite.

- Dolomite (Tectonic(?)Fracture Cement-DC1)

Not overly abundant, post-dates LD2 dolomite and megaquartz, $\delta^{18} \mathrm{O}$ ranges -3.2 to $-9.2 ;{ }^{87} \mathrm{Sr} /{ }^{86} \mathrm{Sr}$ ranges $0.708-0.709$, chemistry same as $\mathrm{LD} 2$ dolomite, grain size ranges from 100-5000 microns, distinctive luminescence ranges from dull green to bright yellow, generally Ca-rich, less radiogenic ${ }^{87} \mathrm{Sr} /{ }^{86} \mathrm{Sr}$ than host rocks.

- Dolomite (Tectonic Fracture Cement-DC2)

100-7500 microns grain size, banded orange luminescence, some non-luminescent bands due to elevated iron content, $\delta^{18} \mathrm{O}$ ranges -7.2 to -10.5 , more radiogenic ${ }^{87} \mathrm{Sr} /{ }^{86} \mathrm{Sr}$ than host rocks, ratio ranges from 0.7092 to 0.713 , heaviest oxygen isotopes.

- Pyrite (Tectonic Fracture Cement-PT2)

Found as fracture linings, appears to be final cement phase in many open fractures, thought to be high-temperature phase synchronous with other metallic phases observed throughout region.

\section{Late Post-karst event}

- De-dolomitization and replacement of earlier dolomite fabrics with calcite. Locally important, not widely observed in Andector Field study area. 
Unfortunately, a detailed study of the differences in geochemistry of macroscopically unequivocal karst and tectonic fracture cements has not been attempted. This analysis would permit the refinement of the observations and interpretations outlined above. Most importantly, it would allow us to increase our confidence in non-geochemical methods of assessing fracture genesis in these complex reservoirs.

One trend that appears to be valid is the observation that the system becomes increasingly higher temperature over time due to burial and flow up-section of higher-temperature fluids sourced from deeper (basement?) levels. As part of this process, the system becomes increasingly Fe- and $\mathrm{Mn}$-rich, leading to deposition of metallic phases in fracture cements. The presence of metallic phases in a fracture indicates the likelihood that it has remained open from its karst genesis, and/or that it formed and was infilled during tectonic deformation. The presence of earlier crystalline phases on the fracture walls and/or the geometry of the fracture can help differentiate between these two cases. It is important to emphasize that open fractures formed during both events are able to significantly enhance the productivity of the reservoir. Work in progress is attempting to refine the timing sequence of the different geochemical phases relative to the tectonic deformation events.

\section{FRACTURE DATA SYNTHESIS}

The Phillips South Fault Block Unit (SFBU) \#4-62 well was drilled in 1988 and an oriented core was taken through the entire Ellenburger producing interval and upper basement.

A detailed fracture analysis was made shortly after recovery of the Phillips SFBU \#4-62 core, and a preliminary analysis was made of the fracture systems. This work, performed by an outside contractor, analyzed numerous fracture attributes including: fracture azimuth, fracture dip, length, aperture, effective aperture (total less mineralization), percent mineral infill, presence of oil staining, sedimentary and tectonic features, host rock lithology, fracture infill cement composition, and interpreted fracture origin. In addition, numerous analyses of various engineering parameters were made to assess deliverability and related fluid response during production. Several samples were taken and Anelastic Strain Recovery Analysis (ASCA) was performed to determine the orientation of the principal horizontal stress in the well. These data indicate a maximum horizontal compressive stress oriented along a $103^{\circ}$ azimuth, $\sim \mathrm{E} / \mathrm{W}$ (Rhett, 1998).

The initial service company-provided fracture data presentation was not based on geologic constraints. Instead, the data were analyzed by cored interval. Recently, we have developed a geologic framework which greatly enhances the information that can be obtained from this core. Most importantly, it permits us to understand the relative importance of karst and tectonic fractures in the largest Ellenburger reservoir in West Texas. This framework uses the diagenetic sequence worked out using the matrix and fracture cement chronologies.

Using the diagenetic sequence established, we have separated the fracture data set for the Phillips South Fault Block Unit \#4-62 by the fracture infill mineralogy. We have then identified the relative importance of karst and tectonic fractures in the well. Work in progress involves attempting to model the genesis of these fractures and the field extent of the different fracture systems, using production rate data calibrated against the core fracture data from the SFBU \#4-62 well.

In the diagenetically-constrained fracture sequence, we have initially assessed the significance of orientation possessed by the different fracture sets. Figures 18-21 summarize the orientation data for the 
different fracture data sets separated by mineral infill. We have performed a similar analysis using scatterplots to constrain relationships between depth, fracture length, aperture, etc. This analysis places considerable constraint on the appropriate fracture data attributes to be placed in a reservoir simulation environment.

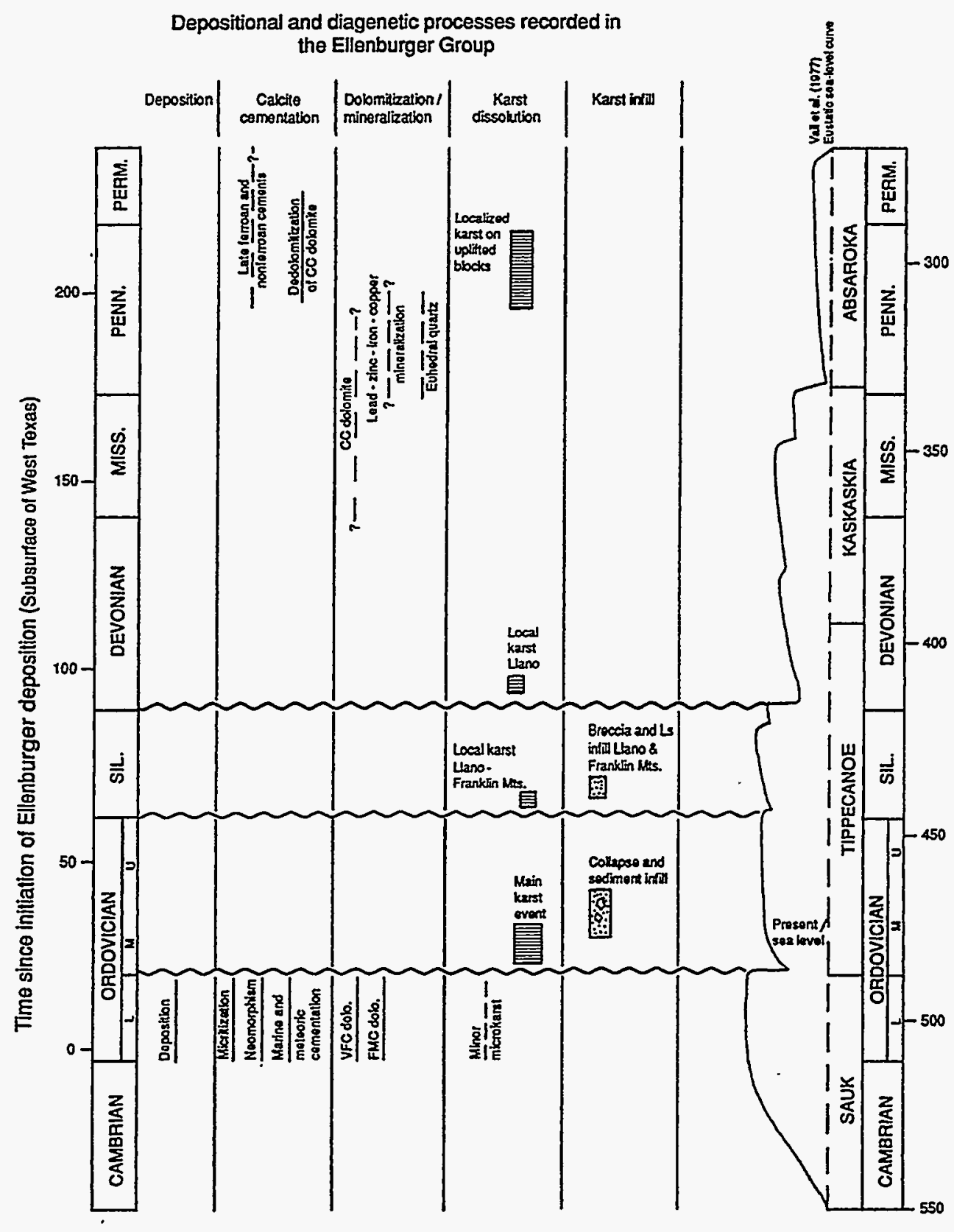

Figure 16: Simplified regional diagenetic sequence and karstification timeline of Kerans (1990). Additional detail used in this study was provided by integrating Kupecz (1989) along with new data collected and interpreted as part of this study. 


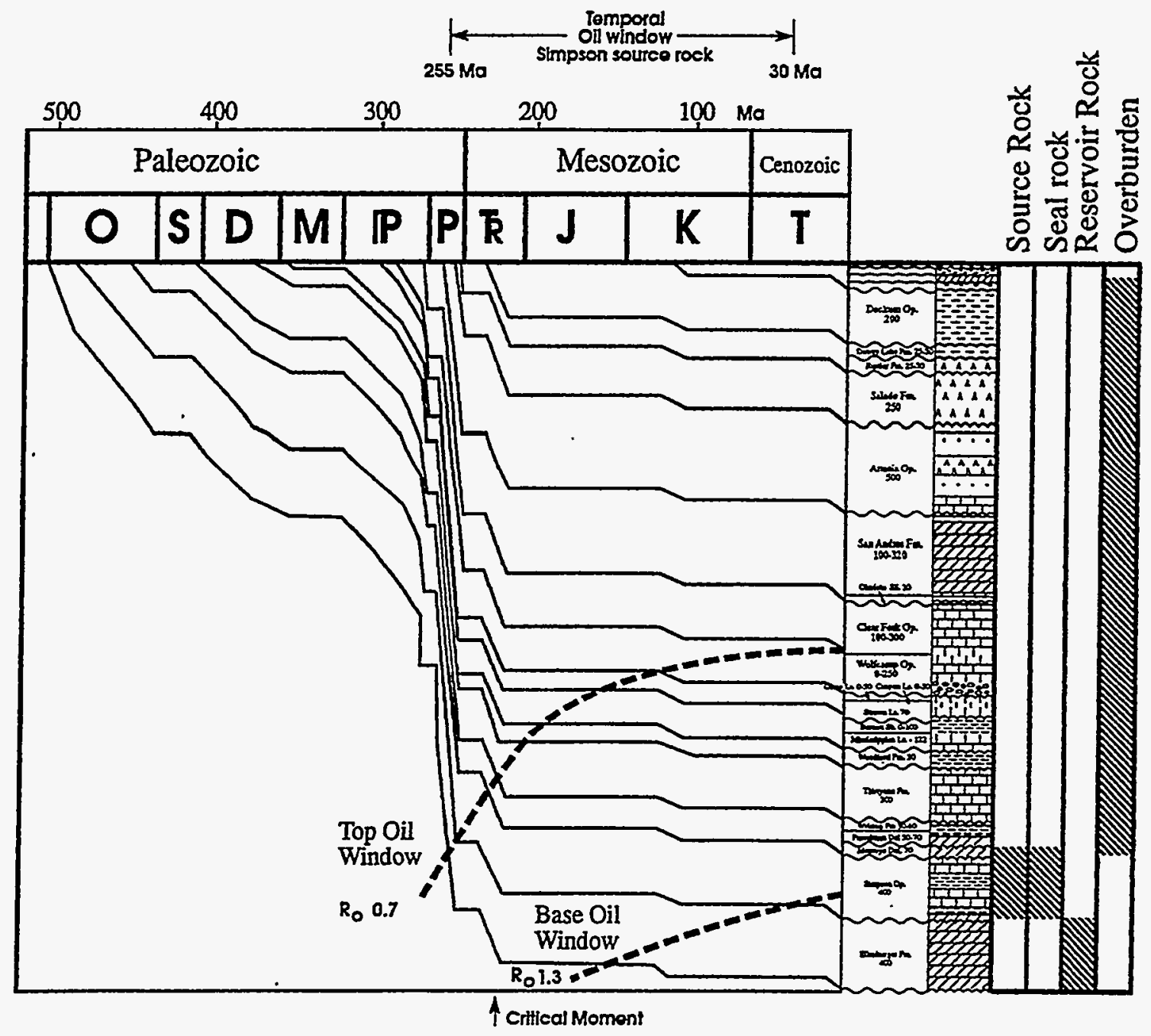

Figure 17: Burial history plot for Andector Field constructed by Katz et al. (1994). Note relative timing of deformation and migration. 


\section{ORIENTATION CHARACTERISTICS OF MINERALIZED FRACTURES}

\section{All Fractures (complete data set composed of only natural fractures):}

The entire fracture database shows a predominance of NE-trending fractures with fractures striking along nearly every compass orientation (total of 1320 fractures). The rose diagram in Figure 18 illustrates the initial data set and the need to subdivide the data using meaningful geologic constraints. Note that the oil-stained fractures subset shows three to four primary trends corresponding to NE, WNW, NE and N-S orientations. It is important to emphasize that the oil-stained subset (395 fractures) corresponds to $30 \%$ of the total data. The trends observed in both data sets are also similar to the patterns recognized in Ellenburger faulting and linear features analysis performed on LANDSAT TM imagery and aerial photos (e.g. Hoak et al., 1998).

\section{Anhydrite-filled fractures:}

There are relatively few anhydrite mineralized fractures ( 48 total). In general, they appear to be restricted to the upper part of the cored interval (top Ellenburger). There origin is enigmatic because they appear to be a late-phase and are not abundant. Because the only source of evaporite minerals. is found in the Permian section, it is possible that these are fairly recent features formed by downward percolation of overlying Permian formation waters, though unlikely given the thick shale seal overlying the Ellenburger. The majority of anhydrite mineralized fractures trend NE and NNW, with lesser fractures present along a NW and WNW trend (see Figure 18). Similar trends are observed for the oilstained subset with a less-pronounced NNW trend. This may reflect the unfavorable orientation of this azimuth relative to the modern-day principal horizontal compressive stress which trends ENE. Note that the majority of anhydrite fractures are oil-stained ( $80 \%$ or 38 fractures).

\section{Calcite-filled fractures:}

Calcite mineralized fractures show a dominance of NE, NNE and NW trends (Figure 19). There are 194 total fractures with only 15 fractures showing oil-staining. The oil-stained fractures show a dominance of NW trends. This, in conjunction with the diagenetic history, suggests that these fractures formed early and were largely completely cemented by the time of oil migration. The data plot showing the difference in effective vs. measured fracture width (a measure of cement infill completeness) shows that most calcite cemented fractures are completely cemented. This will be discussed in detail in later sections.

\section{Clay-filled fractures:}

Clay-filled fractures show a dominant trend to the WNW, N-S, NE and ENE (Figure 19). These fractures are rare (only 20 total) and a high percentage of these are oil-stained (11 total). Oil staining is dominant along the WNW trend. The timing of these fractures is equivocal. Despite the presence of oilstaining, it is thought that these fractures are probably syn-karst because many of the clay-rich fractures appear similar to the green clays in the basal Simpson Group that overlies the Ellenburger along the subaerial exposure surface. This interpretation is supported by their restricted occurrence in the shallowest cored interval of the Ellenburger.

\section{Dolomite-filled fractures:}

Dolomite-filled fractures are the most dominant fracture set (673 total). Nearly $50 \%$ of these fractures are oil-stained. The dominant trends for the un-stained set are WNW, NW and NE, although there is an abundance of other orientations (Figure 20). In the oil-stained subset, the dominant trends area similar although the N-S, NNE trend significance is reduced. 


\section{Pyrite-filled fractures:}

Pyrite-filled fractures are dominated by a NE-trending set (121 total fractures). Figure 20 outlines the major orientations. Both sets are dominant in the deeper section of the cored interval. The oil-stained fractures trend ENE, are comparatively rare, and compose only $\sim 7 \%$ of the total (total of 9 fractures). Because of this paucity, pyrite-filled fractures are considered of limited importance to reservoir quality. These fractures are interpreted to be one of the latest events because of the high temperature genesis of the metallic phases observed in the system. As such, the oil-stained fractures parallel the dominant direction of the greatest horizontal compressive stress. Similarly, the non-oilstained fractures show a similar maxima along the same orientation, suggesting that they formed under this stress state.

\section{Quartz-filled fractures:}

Quartz mineralized fractures (total of 34 fractures) are also restricted to the deeper section of the cored interval (Figure 21). Their geochemistry is associated with the pyrite-mineralized fractures and is inferred to be of a high-temperature origin (60-100 degrees Celsius) relative to the matrix protolith. The quartz mineralized fractures show four primary trends. WNW, NW, NE and ENE. Very few of these fractures show oil-staining (total of 3 fractures), probably reflecting the observation that most of the quartz-filled fractures are nearly completely cemented. As a result, their importance to reservoir quality is thought to be minimal.

\section{Unmineralized fractures:}

Unmineralized fractures are probably a combination of drilling-induced and tectonic fractures (Figure 21). They are an interesting subset of data because if they are of karst origin, they do not appear to have been extensively cemented during the burial diagenesis that appears to have strongly affected most other fractures. Based on these observations, we believe that most of these fractures are either of tectonic or drilling-induced origin (total data set of 229 fractures). The dominant WNW trend probably reflects the drilling induced fractures generated by drilling in a modern-day maximum horizontal compressive stress field possessing an orientation of 103 degrees azimuth. Induced fractures would tend to align parallel to this orientation $(\sim \mathrm{E} / \mathrm{W}$ or $\sim \mathrm{WNW}$ trend). The dominant $\mathrm{NE}, \mathrm{NW}$ and $\mathrm{NNW}$ trends probably reflect tectonic fracturing similar to that seen in the underlying basement.

\section{Basement fractures (Precambrian-age, mica schist lithology):}

Basement fractures are probably a combination of drilling-induced and tectonic fractures (total of 151 fractures). Because the host rock lithology (mica schist) is unaffected by karst processes, these basement fractures represent the typical intensity of tectonic fracturing. There are two primary trends, an E/W trend and a NNW trend (Figure 22). There are lesser intensity trends parallel to the NE and NW. The foliation in the basement rocks trends NW and dips to the southeast. There is a prominent downdip lineation found on the foliation planes. Some interpreted NW-trending fractures may be foliation planes. There does not appear to be any evidence for a second foliation or a crenulation cleavage of the earlier fabric.

It is possible that Precambrian-age fractures may be present in this lithology. These would have formed during regional uplift and prior to deposition of Cambrian and younger siliciclastics and carbonates. The close parallelism between the dominant NW, NE and WNW fracture sets observed in this cored interval and the overlying Ellenburger suggests that karstification and tectonic fractures followed older fracture anisotropy trends, or that the fractures formed during the same Pennsylvanianage tectonic event as the Ellenburger tectonic fracturing. Given that some of the basement fractures show similar mineralization to the shallower Ellenburger tectonic fractures, we believe that most of the basement fractures are Pennsylvanian in age. 


\section{Fracture Significance (Tectonic vs. Karst-related):}

Previous studies (e.g. Kerans, 1990; Loucks and Handford, 1992) have minimized the importance of tectonic fractures and have emphasized the overwhelming importance of karst-related processes. This makes development of an exploration model more complex, particularly because of the difficulty of accurately predicting the location and areal extent of karst-related reservoirs, particularly the high-permeability zones. The conclusions of these karst-dominated workers is in sharp contrast to the work of Ijirigho and Schreiber (1986) who suggested that nearly all Ellenburger fractures are of tectonic origin. To assess the relative importance of tectonic fractures compared to karst-related features, we evaluated the SFBU core data.

Tectonic fractures compose 380 total fractures (unmineralized + basement) of the total 1090 mineralized fractures found in the Ellenburger. This would suggest that $~ 35 \%$ of all fractures are tectonic in origin. This, however, does not accurately reflect the observation that the quartz and pyrite mineralized fractures are of tectonic origin. If we add the quartz and pyrite fractures (total of 155 fractures) to the tectonic fracture data set and subtract these from the mineralized data set, we find 535 out of 935 of the fractures are of tectonic origin. This indicates that $57 \%$ are of tectonic origin. Note that we have assumed that all the dolomite-mineralized fractures possess a karst origin. From our diagenetic sequence analysis and synthesis, we know that a considerable percentage of the dolomite fractures are tectonic in origin. The few unmineralized fractures that may be drilling-induced are more than offset by the number of dolomite-mineralized tectonic fractures.

We conclude that tectonic fracturing represents a critical influence, particularly in light of production rate analyses which suggest that the Phillips SFBU \#4-62 shows smaller maximum flow rates than areas adjacent to fault zones. This in turn, indicates, that tectonic fracture permeability adjacent to fault zones is likely much greater than in the Phillips SFBU \#4-62 core from the structural culmination where flexure-related fracturing should be greatest. Exploration and field development models that address only karst-related fracturing seriously under-represent one of the major sources of fracture permeability. 
Phillips- SFBU \#4-62

Ector County, Texas

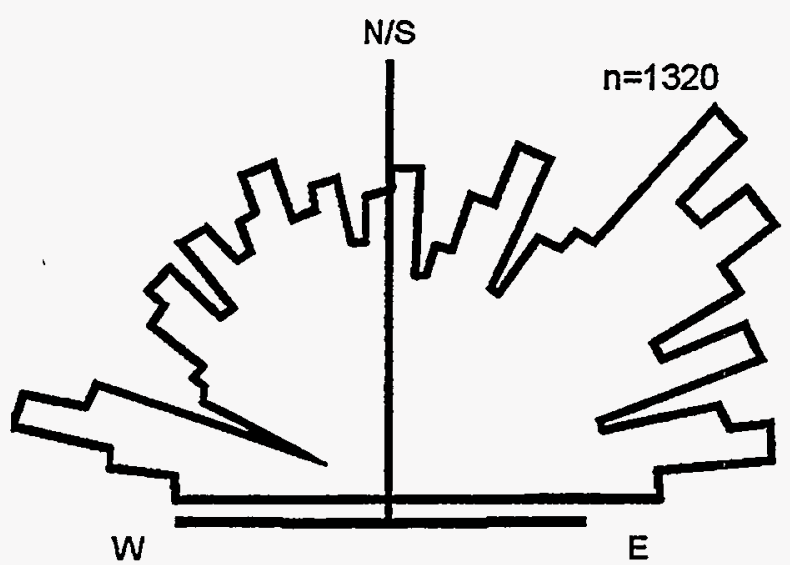

all natural fractures
Phillips- SFBU \#4-62

Ector County, Texas

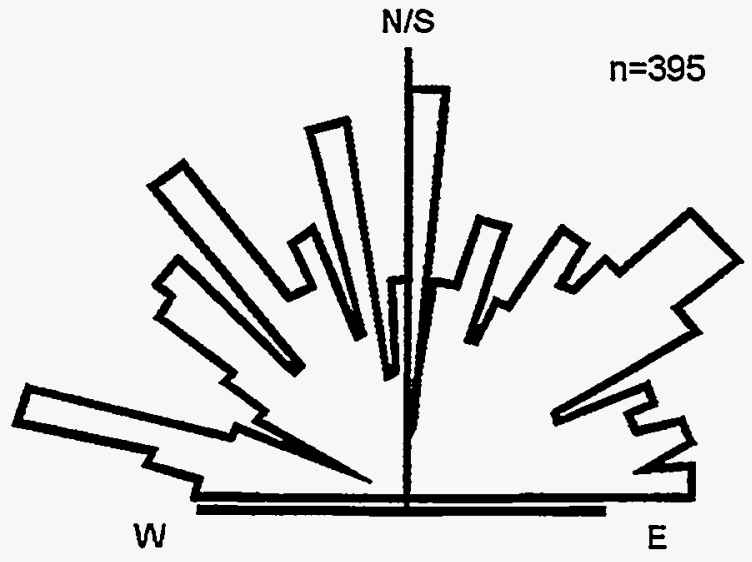

all oil-filled fractures
Phillips- SFBU \#4-62

Ector County, Texas

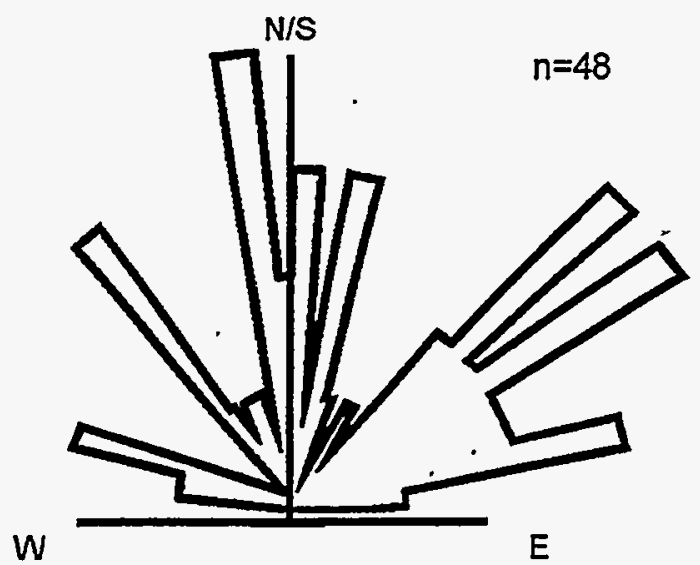

all anyhydrite mineralized fractures
Phillips- SFBU \#4-62

Ector County, Texas

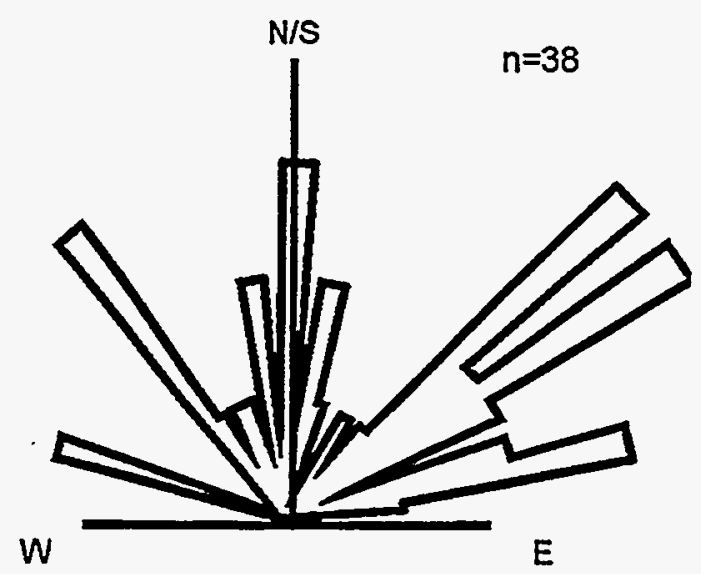

all oil-filled anyhydrite mineralized fractures

Figure 18: Rose diagrams showing orientation and frequency distribution of all natural fractures and all anhydrite mineralized natural fractures. See text for discussion. 
Phillips- SFBU \#4-62

Ector County, Texas

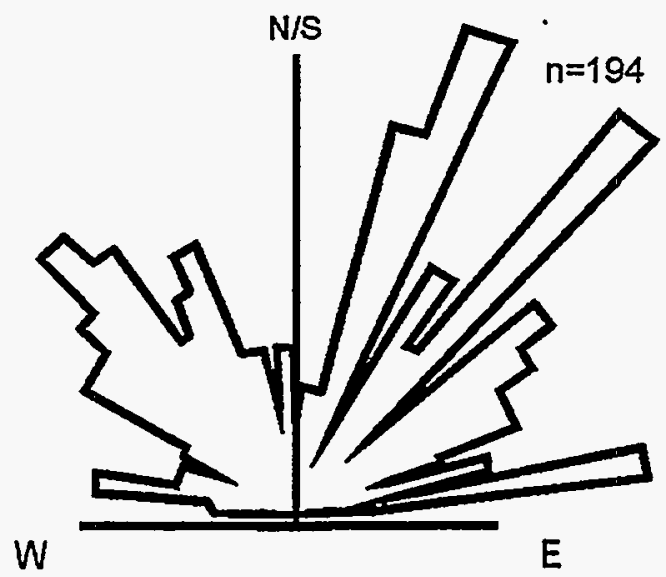

all calcite mineralized fractures
Phillips- SFBU \#462

Ector County, Texas

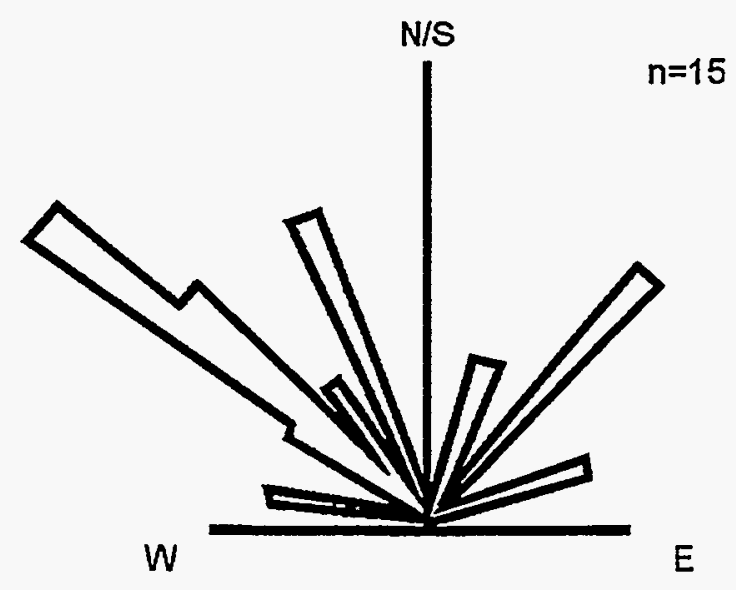

all oil-filled calcite mineralized fractures

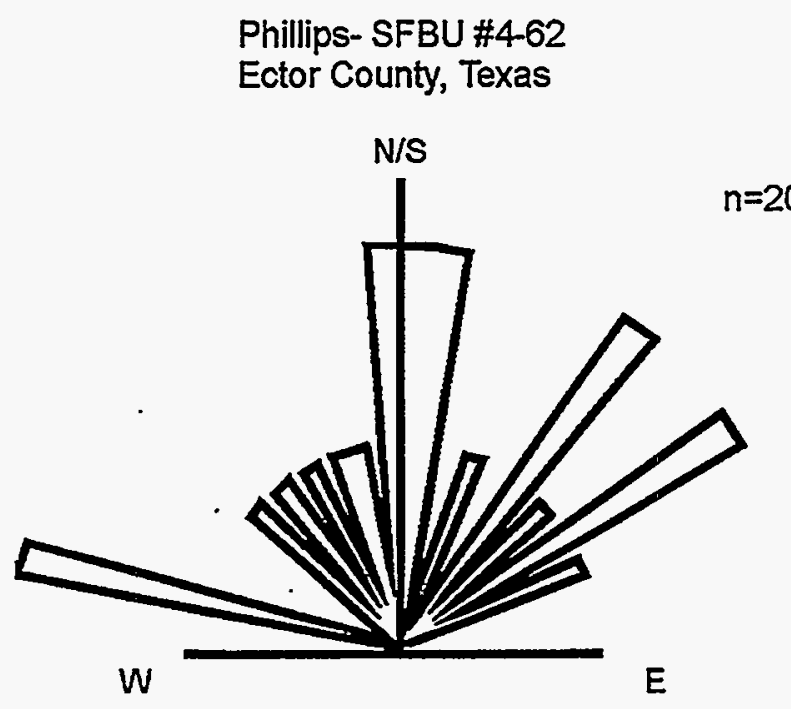

all clay mineralized fractures
Phillips- SFBU \#4-62

Ector County, Texas

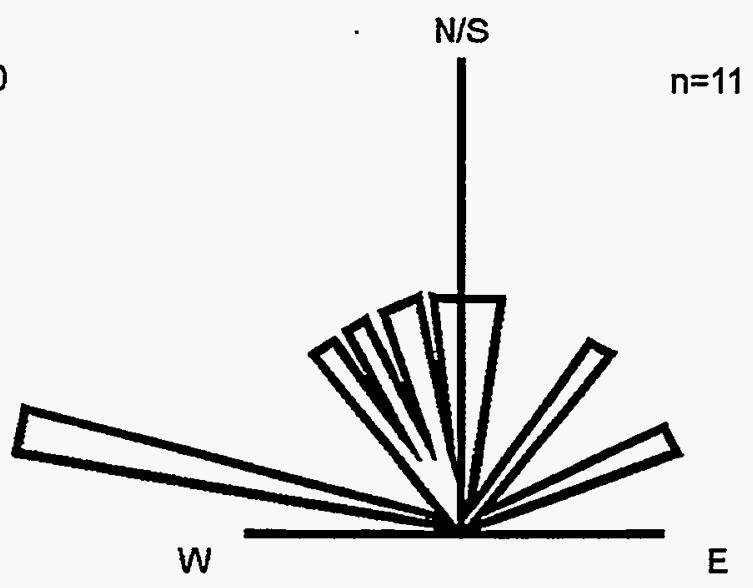

all oil-filled clay mineralized fractures

Figure 19: Rose diagrams showing orientation and frequency distribution of all calcite mineralized fractures and all clay mineralized natural fractures. See text for discussion 
Phillips- SFBU \#462

Ector County, Texas

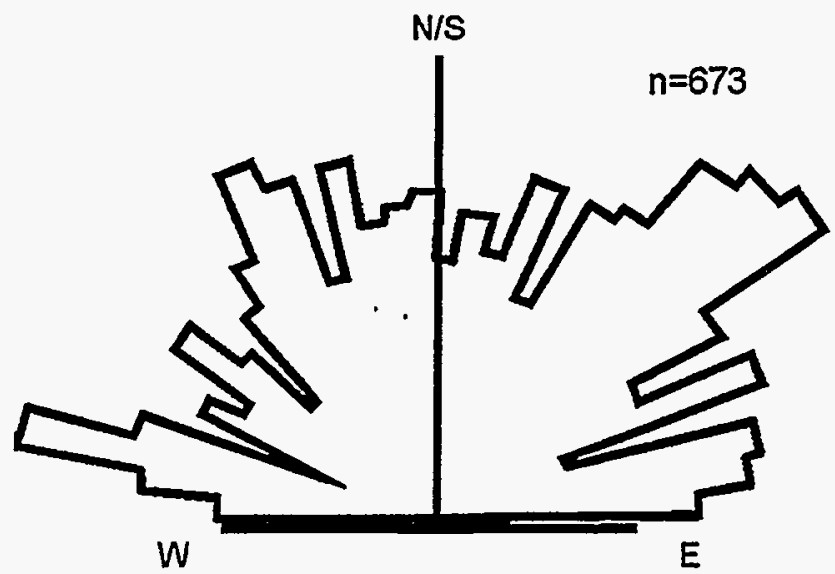

all dolomite mineralized fractures
Phillips- SFBU \#4-62

Ector County, Texas

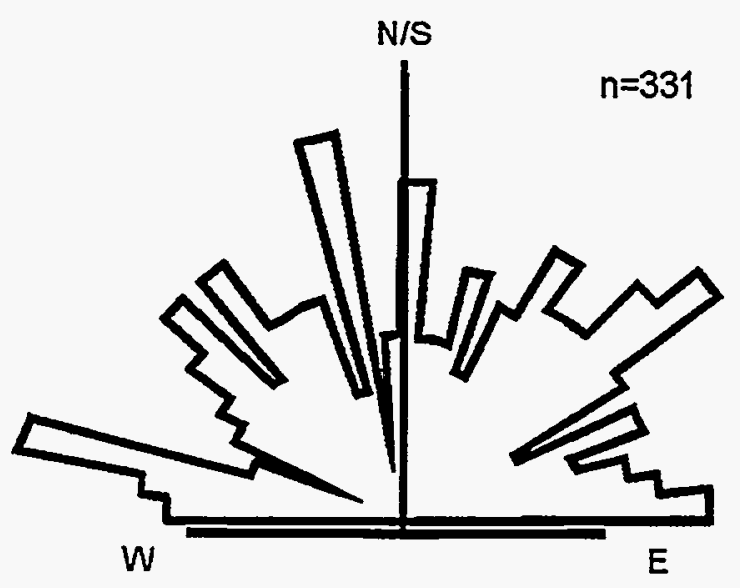

all oil-filled dolomite mineralized fractures
Phillips- SFBU \#4-62

Ector County, Texas

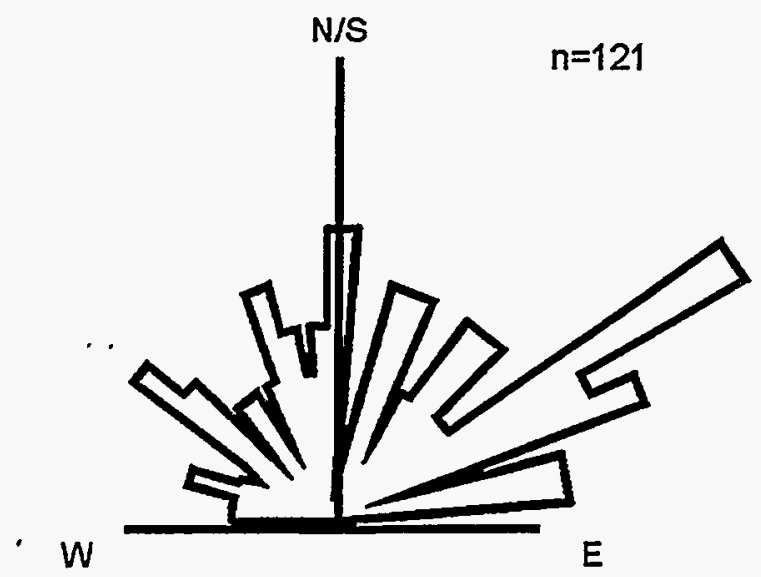

all pyrite mineralized fractures
Phillips- SFBU \#4-62

Ector County, Texas

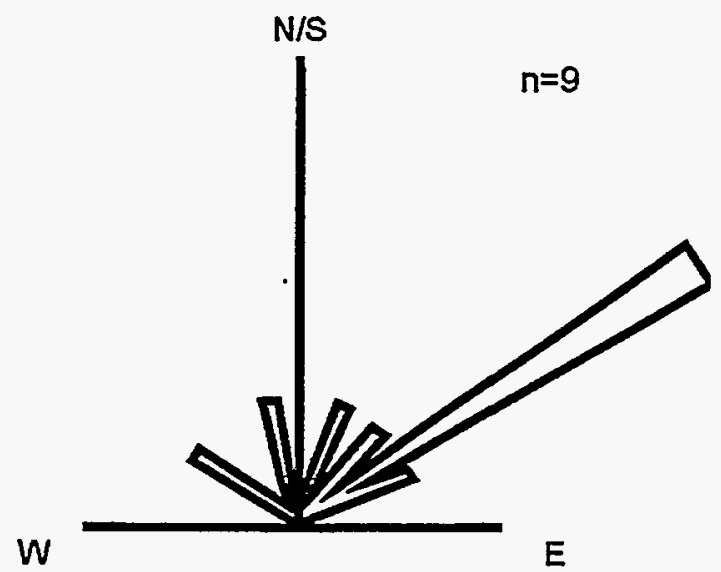

all oil-filled pyrite mineralized fractures

Figure 20: Rose diagrams showing orientation and frequency distribution of all dolomite mineralized fractures and all pyrite mineralized natural fractures. See text for discussion 
Phillips- SFBU \#4-62

Ector County, Texas

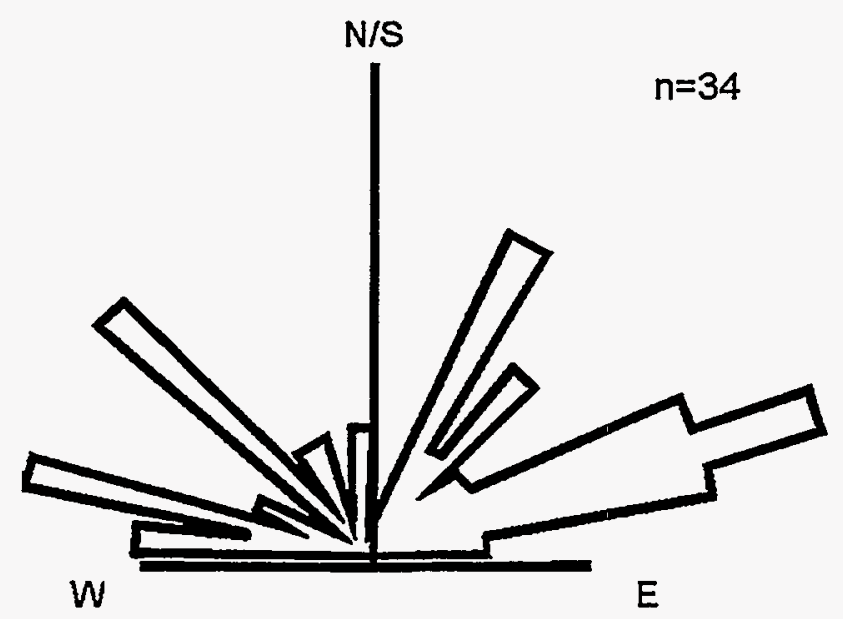

all quartz mineralized fractures
Phillips- SFBU \#4-62

Ector County, Texas

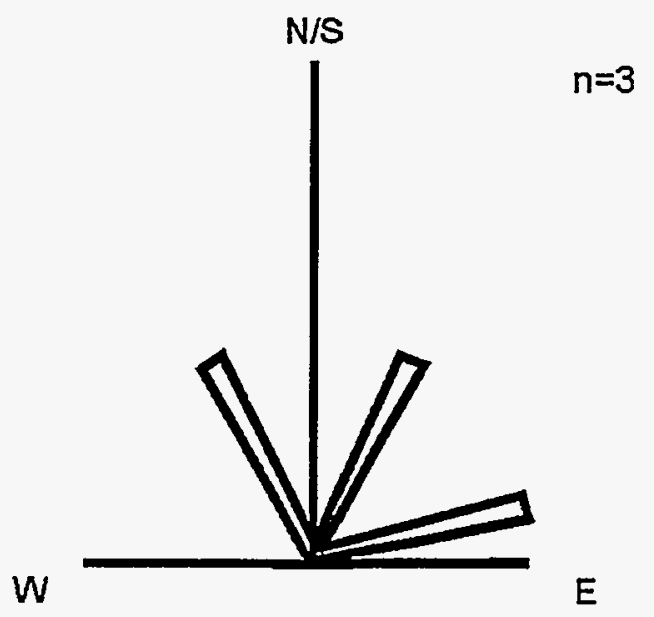

all oil-filled quartz mineralized fractures

Phillips- SFBU \#4-62

Ector County, Texas

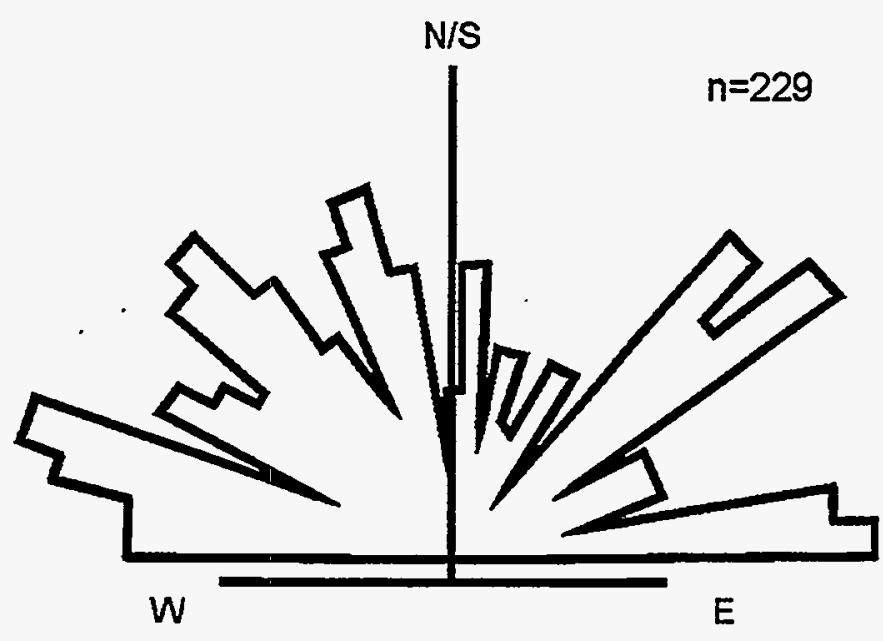

all unknown mineralized fractures

Figure 21: Rose diagrams showing orientation and frequency distribution of all quartz mineralized fractures and all unknown mineralized fractures. See text for discussion 
Phillips- SFBU \#4-62

Ector County, Texas

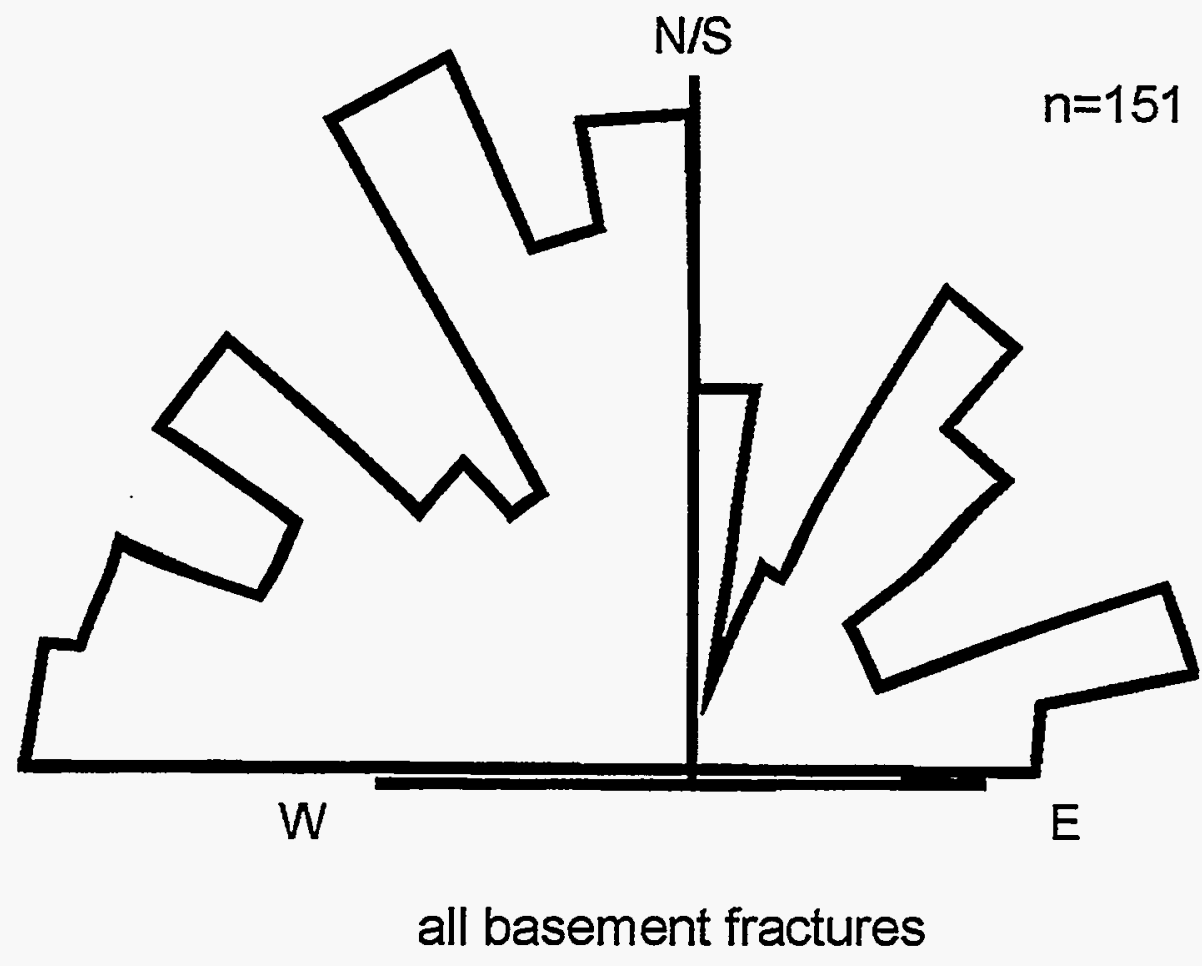

Figure 22: Basement fractures (mineralized and unmineralized fractures in mica schist Precambrian host rock). These fractures are unequivocally tectonic in origin. Fracture origin prior to Ellenburger deposition is unlikely due to close correspondence in dominant fracture trends between Ellenburger and basement. Metamorphic foliation in basement trends northwest and dips to southeast. 


\section{ATTRIBUTES OF MINERALIZED FRACTURES}

In addition to the orientation analysis, we also characterized the fractures based on their nonorientation specific attributes. Fracture apertures for broken fracture surfaces (generally very thin apertures) were assumed to have a width of $0.01 \mathrm{~mm}$. This represents the lower limit for measurement using the measuring equipment available in the field. We delineated the same data subsets as performed in the previous orientation analysis section based on the mineral infill sequence.

All Mineralized Fractures (complete data set composed of only mineralized fractures):

Fracture lengths of all mineralized fractures (Figure 23)(total of 1320 fractures) as measured in the SFBU \#4-62 drill core range from 5-750 mm length, show a range of fracture aperture widths ranging from .01 to $10 \mathrm{~mm}$, are dominantly high-angle ( $>70$ degrees dip), posses length:width ratio around 100:1, show a wide range of occlusion by mineral cements, and show a close correspondence between measured and effective fracture aperture. The latter indicates that a considerable percentage of fractures are open in the subsurface and contribute to reservoir deliverability.

\section{Anhydrite-filled fractures:}

The anhydrite-mineralized fractures (Figure 24) (total of 48 anhydrite-filled fractures) show a range of lengths ranging from $3-250 \mathrm{~mm}$, and aperture widths ranging from .01 to $5 \mathrm{~mm}$. The majority of these fractures are completely occluded by mineralization and their expected contribution to reservoir quality is probably small. The thicker fractures show an approximately 50:1 length:width ratio. The late origin of these fractures suggests they represent diagenetic infill of open fractures during the Permian. The genesis of these fractures and their subsequent infill history is equivocal and problematic. Their restriction to the shallower part of the reservoir where reservoir quality is poorest underscores the importance of understanding the role of anhydrite cements in reducing reservoir quality.

\section{Calcite-filled fractures:}

Calcite-filled fractures (Figure 24) are also restricted in occurrence to the shallowest cored interval (total number of calcite-filled fractures is 194). They show a range of lengths ranging from 5$500 \mathrm{~mm}$ and an aperture of $.01-10 \mathrm{~mm}$. They show a considerable amount of occlusion (effective aperture) due to mineralization and are probably not major contributors to reservoir deliverability. They show an average length:width ratio of approximately 100:1. These fractures are thought to be related to karst processes because they are generally crosscut by all other (later) cement phases.

\section{Clay-filled fractures:}

Clay-filled fractures (Figure 25) are rare (total of 20 clay-filled fractures), and appear restricted in occurrence to the shallowest cored interval. Whether this reflects infill detritus from the overlying Simpson Group is unknown, although the green appearance and composition appear similar to the overlying Simpson Shales. These fractures show a range in length from 5-500 $\mathrm{mm}$ and an aperture range from $.01-7.5 \mathrm{~mm}$. They are typically fairly open fractures and possess an effective vs. measured aperture ratio close to 1 . The average length:width ratio is approximately 100:1. These fractures are thought to be related to karst processes although their temporal relationship to other fractures is unclear in most examples.

\section{Dolomite-filled fractures:}

Dolomite-filled fractures (Figure 25) are the most common phase and are found throughout the cored interval (total of 673 dolomite-filled fractures in core). The fracture lengths range from $2-800 \mathrm{~mm}$ and they possess apertures ranging from $.01-10 \mathrm{~mm}$. They show two primary clusters of data corresponding to completely infilled fractures (effective width of .001) and more open fractures which 
possess an effective vs. measured aperture ratio close to 1 . The typical length:width ratio is approximately 80:1. The majority of these fractures are probably related to karst processes and were cemented during burial diagenesis. Some of these fractures are tectonic in origin. These fractures are the most difficult to establish their genesis. For this reason, we focused our geochemical analysis on the dolomite fracture cements. These results (see later discussion in this paper) suggest that most of these dolomite fracture fill cements represent precipitation under elevated temperatures. Whether this occurred during diagenetic cementation of open, karst-formed fracture voids during burial diagenesis, or during active tectonic deformation and subsequent precipitation cannot be determined in most cases. Only where high-angle fractures crosscut karst breccias and cemented breccias can the origin be unequivocally determined. It should be emphasized that no evidence of syntectonic mineral phases were identified (e.g. fibrous syntaxial or antitaxial crystals). Additional analysis is necessary to confirm this observation and its significance although nearly twenty five Ellenburger cores were analyzed around Ector County and no fibrous syntectonic veins were observed. This syntectonic behavior may also be lithologically controlled and the absence of such fabrics in the Ellenburger may indicate intense and rapid brecciation of Ellenburger host rock that effectively precluded the slow fracture dilation rates needed for syntectonic mineral phase precipitation.

\section{Pyrite-filled fractures:}

Pyrite-filled fractures (Figure 26) are relatively uncommon(total of 121 pyrite-mineralized fractures), and restricted in occurrence to the deeper cored intervals. The fracture lengths range from 5$300 \mathrm{~mm}$ and they possess apertures ranging from $.01-8 \mathrm{~mm}$. The majority of these fractures are open (effective vs. measured aperture ratio close to 1 ). The typical length:width ratio is approximately 100:1. These fractures are thought to be of tectonic origin and several examples have been found where pyrite encrusts karst-related voids that show an earlier dolomite cement phase on the cavity surface.

\section{Quartz-filled fractures:}

Quartz-filled fractures (Figure 26) are rare (total of 34 quartz filled fractures), and restricted in occurrence to the deepest cored intervals. The fracture lengths range from 10-500 $\mathrm{mm}$ and they possess apertures ranging from $.01-10 \mathrm{~mm}$. The majority of the fractures are tightly cemented and the typical length:width ratio is approximately 100:1. These fractures are thought to be of tectonic origin.

\section{Unmineralized fractures:}

Unmineralized fractures (Figure 27) are primarily found in the deepest part of the core and the basement (total of 229 unmineralized fractures). Only sporadic occurrences are found in the shallower intervals. Because these fractures are unmineralized and thin, they primarily show only two apertures, very thin $(\sim 0.01 \mathrm{~mm})$ and thin $(\sim 0.1 \mathrm{~mm})$. These fractures range in length from $1-165 \mathrm{~mm}$ and are thought to have formed by tectonic processes. Given that most of fractures that experienced burial diagenesis and/or formed during tectonic deformation are mineralized, it is considered likely that many of these unmineralized fractures may represent drilling-induced fractures. However, they possess an unfavorable orientation relative to the modern stress regime to have formed during drilling. It is unknown, however, how the regional stress regime varies with depth and within such an anisotropic rock mass such as the basement rocks in Andector Field.

\section{Basement Fractures}

Basement fractures (Figure 27) are common though obviously restricted in occurrence to the deepest cored interval (total of 151 basement fractures). These fractures show a range of lengths (1-200 $\mathrm{mm})$ and are dominated by very thin $(0.01 \mathrm{~mm})$ fractures. They show a length:width ratio of $\sim 5000: 1$. They are unusual fractures because of this very thin, very long geometry. The majority of these fractures are steeply-dipping ( $>70$ degrees). 


\section{Fracture Attribute summary: Implications for reservoir and explorations}

Fracture orientation data integrated with the constraints provided by the modern-day stress state of the Andector Field reservoir (maximum horizontal compressive stress oriented 103 azimuth) indicate that fractures paralleling this azimuth (WNW) will be the most open set. This interpretation is confirmed by the local abundance of WNW-trending fractures in the oil-filled set of the different mineral infillings. Fortunately, given the large amount of mineralization on most fractures, combined with the incompleteness of the mineral infill on these fractures, those fracture sets in a less optimal orientations are also assumed to be open. In general, most of the fractures are infilled with dolomite and reflect a karst origin. Overprinting these karst-related fractures are the pyrite and quartz-filled tectonic fractures. The pyrite fractures are generally open whereas the quartz-mineralized set is generally tightly cemented.

Additional tectonic fracture intensity data are provided by the basement and unmineralized fractures. These data suggest that tectonic fracturing is as important as karst processes in the Phillips SFBU \#4-62 well. This is particularly true if a considerable percentage of dolomite-mineralized fractures formed during tectonic deformation rather than by burial diagenesis infill of karst-formed fractures. In general, the tectonic fractures are primarily an enhancement to flow and reservoir quality for the NE-trending fractures that are dominant in that data set. Given that the tectonic fractures are generally thinner, longer and less influenced by lithologic contrasts in the rock, it is likely that the tectonic fractures represent vertical conduits connecting the karst zones.

For exploration and development programs in West Texas, it is essential that methods to delineate the karst geometry be developed in advance of drilling. Use of 3D seismic data could prove beneficial to identify the seismic signature of the karst zones and map them. Following this analysis, conventional structural analysis can identify the potential for structural traps and tectonic fractures associated with these features. Field development programs should attempt to identify smaller-scale faulting that may significantly enhance reservoir producibility, particularly where these faults and related tectonic systems can link up thick, high-permeability karst breccia horizons.

By integrating analysis of the karst depositional systems along with analysis of tectonic fractures and host structures, it should be possible to clearly identify the potential of the smaller exploration targets that remain undiscovered in the West Texas subsurface. The large number of older oil and gas fields reaching terminal decline also invite a reassessment of their reservoir geometry to identify the karst system geometry, and the relative importance of tectonic fractures on that system. From this new reservoir perspective, it may be possible to develop an engineering program to expand the available reserve base. 

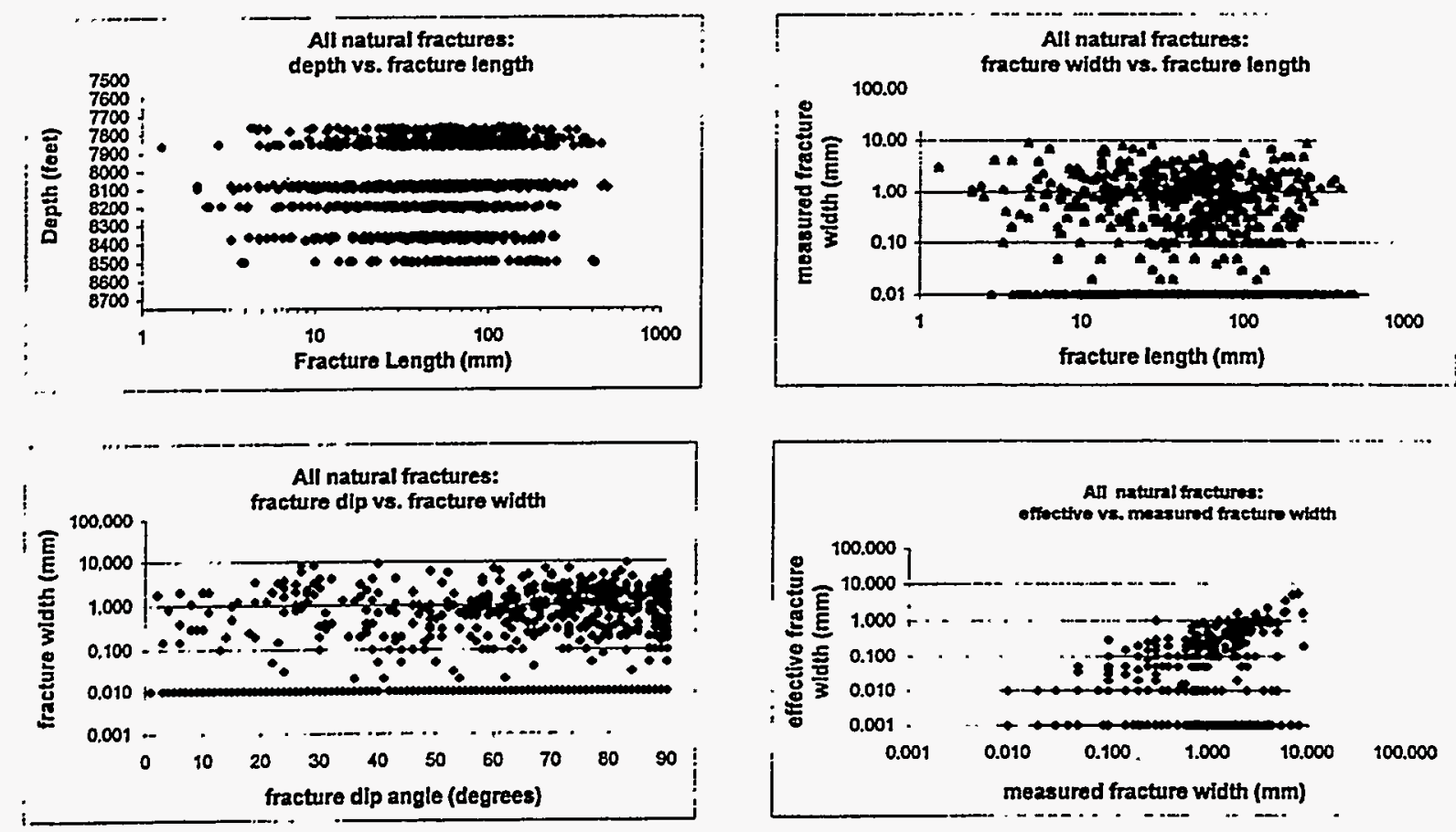

Figure 23: Scatter plots of fracture characteristics for all natural fractures (primarily those with mineralization). See text for discussion. 

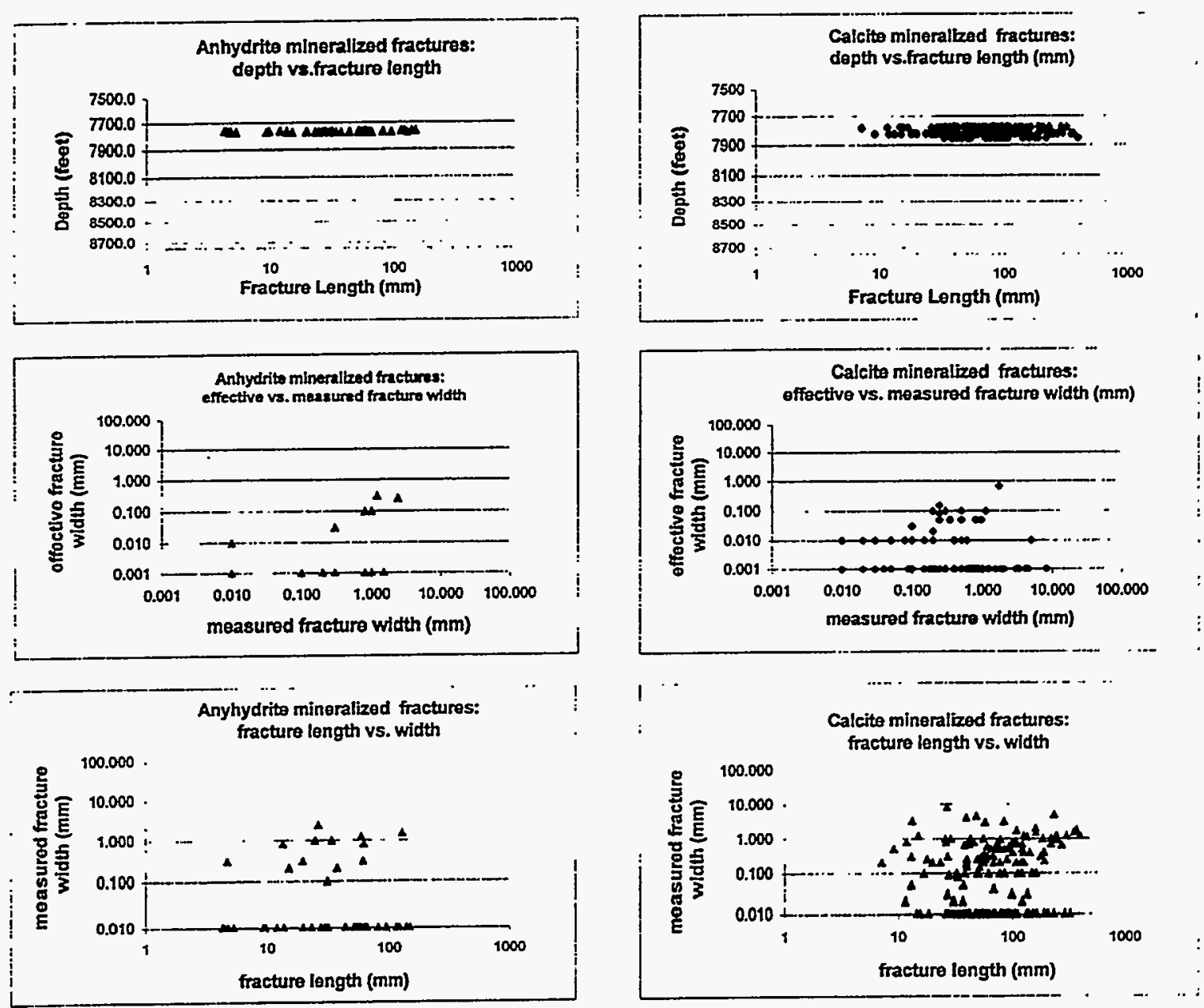

Figure 24: Scatter plots of fracture characteristics for anhydrite and calcite mineralized fractures. See text for discussion. 

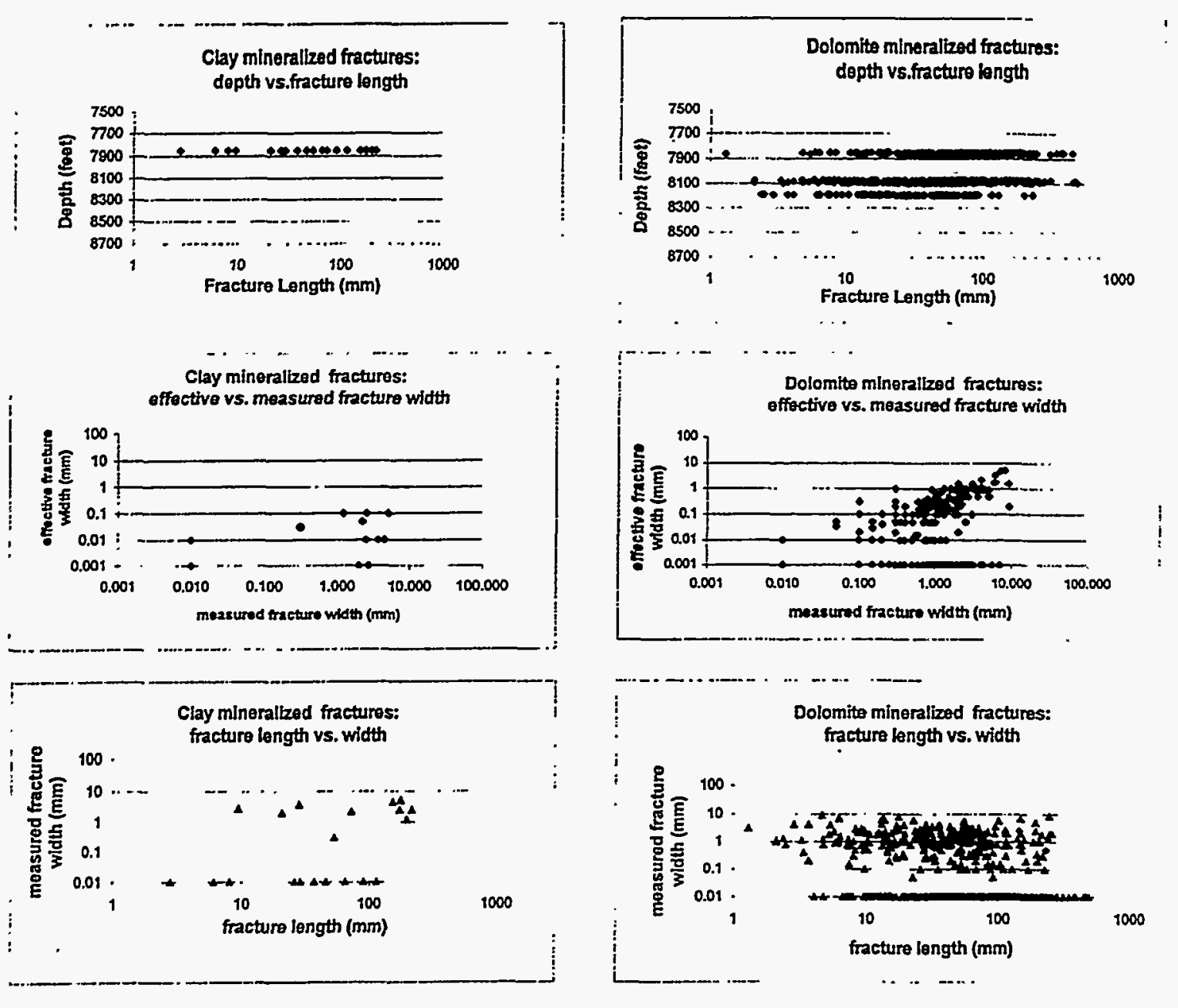

Figure 25: Scatter plots illustrating fracture characteristics of clay and dolomite mineralized fractures. The majority of these fractures are thought to be of karst origin (clay) or a combination of karst processes followed by deeper diagenetic cement infill (dolomite). See text for discussion. 

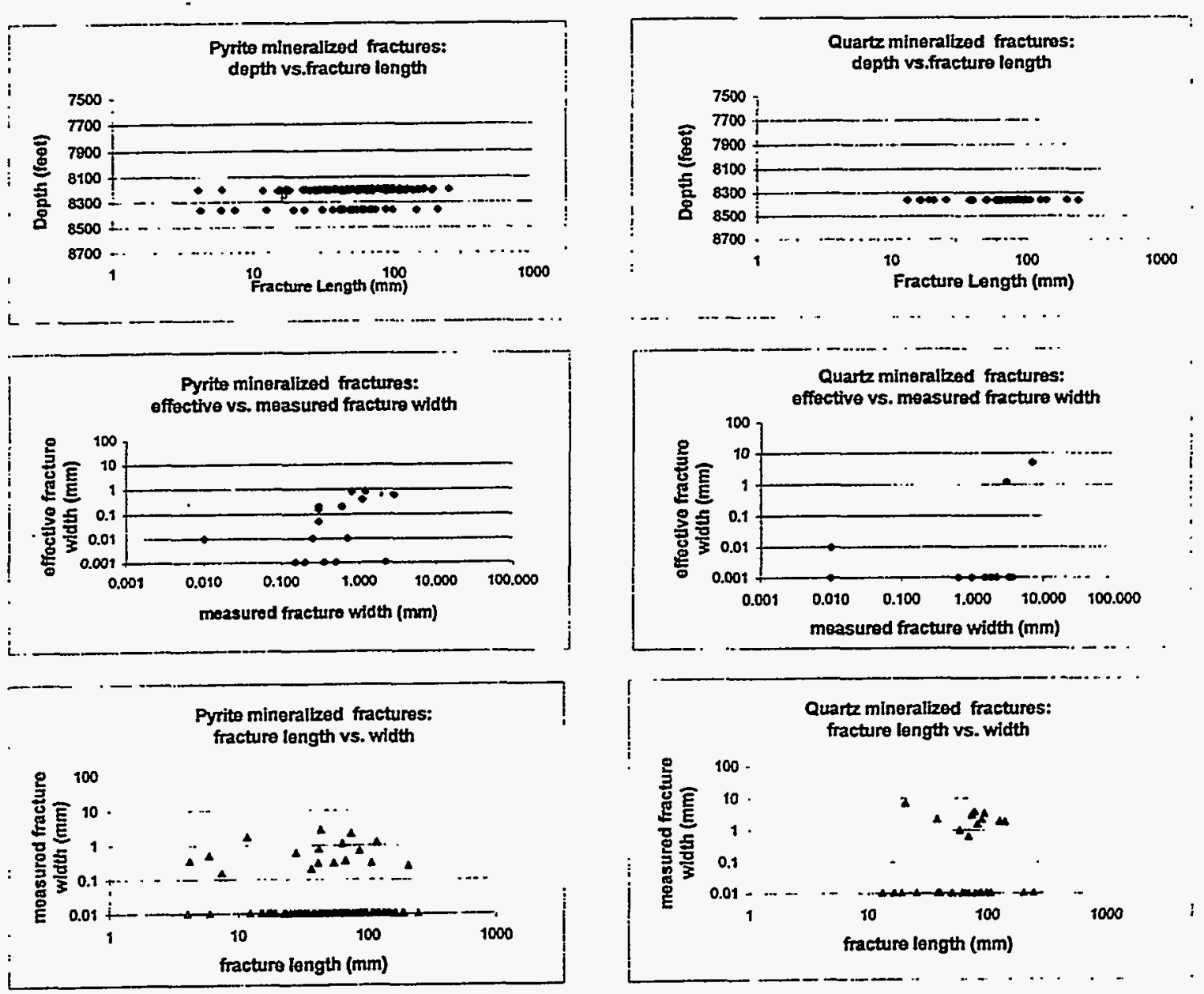

Figure 26: Scatter plots illustrating fracture characteristics of pyrite and quartz mineralized fractures. These fractures are all interpreted to be of tectonic origin. See text for discussion. 

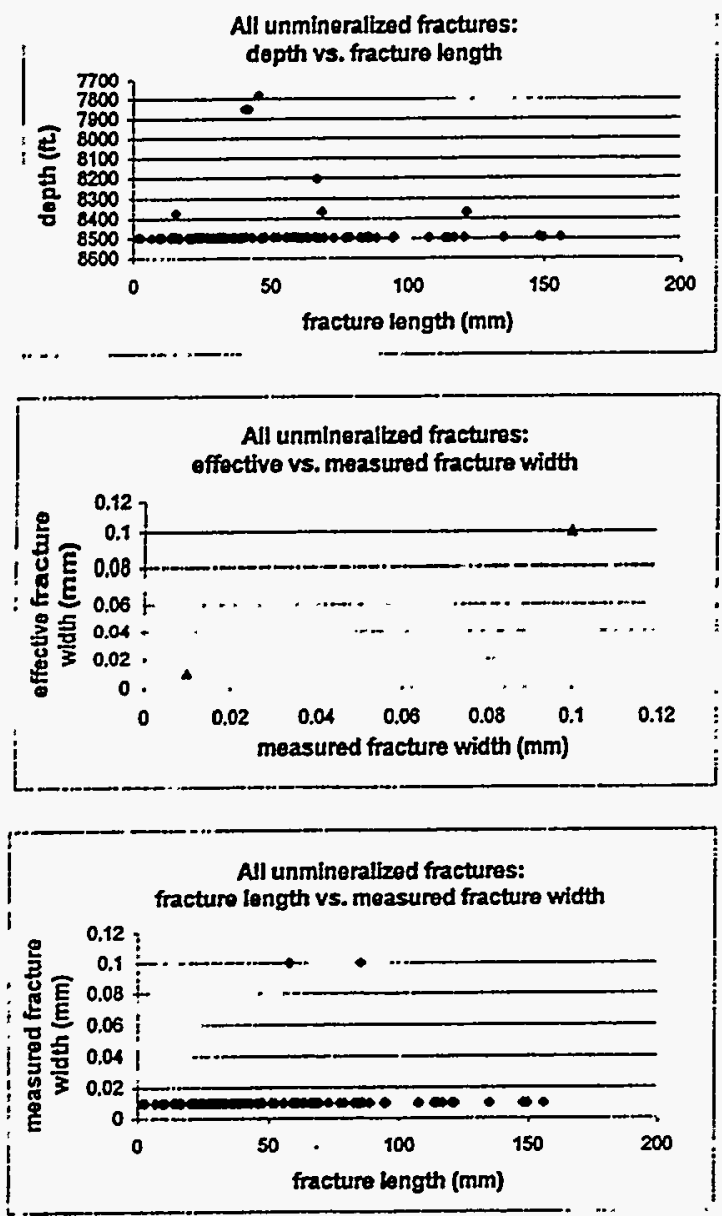
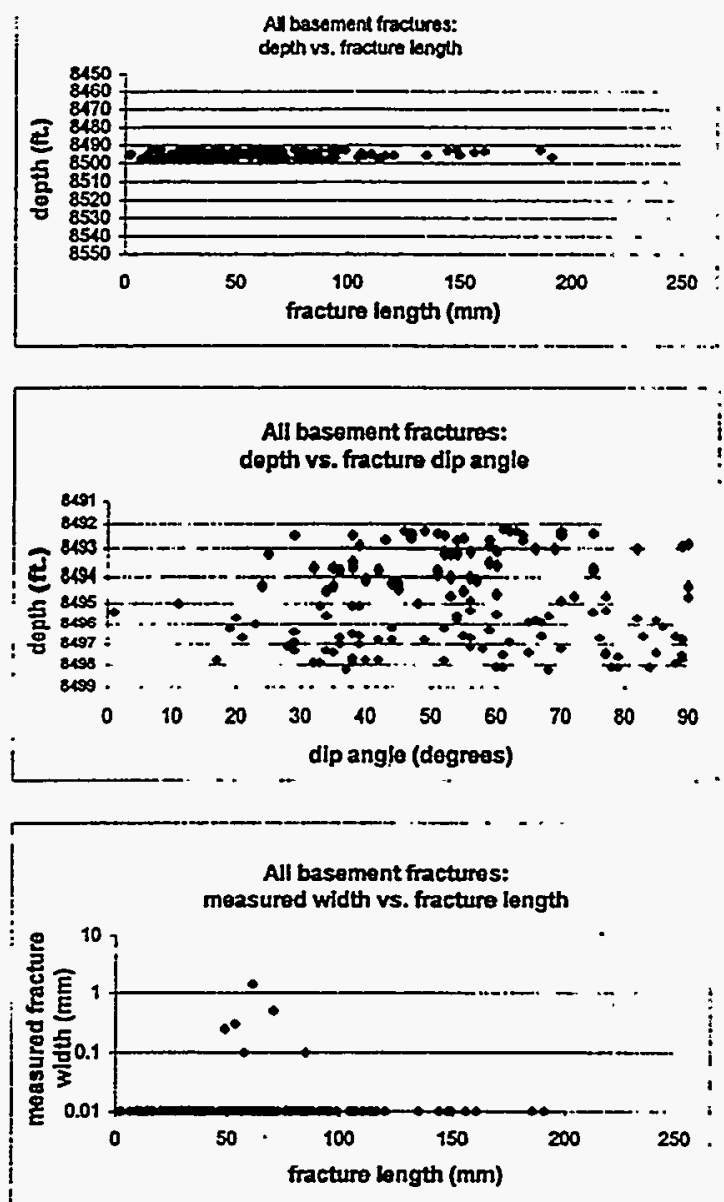

Figure 27: Scatter plots illustrating fracture characteristics for all unmineralized fractures and all fractures in basement (Precambrian-age mica schist) rocks. The majority of these fractures are thought to be of tectonic origin. See text for discussion. 


\section{GEOCHEMISTRY OF FRACTURE INFILL}

Because of the wide variation in timing of the different dolomite fracture cements based on observed crosscutting relationships, from the literature (Kupecz, 1989), and the possibility that many of the dolomite fracture cements could result from either the karst or tectonic fracture phase, we used geochemical and isotopic methods to attempt to distinguish between the different dolomite-mineralized fractures. Due to time constraints, we only performed a limited number of analyses on carefully chosen samples. No cross-cutting relationships were used to further constrain the temporal significance of the results.

From the South Fault Block \#4-62 core, ten analyses of carbon $\left(\delta^{13} \mathrm{C}\right)$, oxygen $\left(\delta^{18} \mathrm{O}\right)$, and strontium $\left({ }^{87} \mathrm{Sr} /{ }^{86} \mathrm{Sr}\right)$ isotopes were performed on fracture infill cements. This information was supplemented by major and trace element geochemical analyses on thirteen samples using ICP-MS (Na, $\mathrm{Mg}, \mathrm{Al}, \mathrm{Si}, \mathrm{K}, \mathrm{Ca}, \mathrm{Ti}, \mathrm{V}, \mathrm{Cr}, \mathrm{Mn}, \mathrm{Fe}, \mathrm{Ni}, \mathrm{Cu}, \mathrm{Zn}, \mathrm{Ga}, \mathrm{Ge}, \mathrm{As}, \mathrm{Se}, \mathrm{Rb}, \mathrm{Sr}, \mathrm{Y}, \mathrm{Zr}, \mathrm{Nb}, \mathrm{Mo}, \mathrm{Ru}, \mathrm{Rh}, \mathrm{Pd}, \mathrm{Ag}$, $\mathrm{Cd}, \mathrm{Sn}, \mathrm{Sb}, \mathrm{Te}, \mathrm{Cs}, \mathrm{Ba}, \mathrm{La}, \mathrm{Ce}, \mathrm{Pr}, \mathrm{Nd}$, Sm, Eu, Gd, Tb, Dy, Ho, Er, Tm, Yb, Lu, Hf, Ta, W, Re, Os, Ir, $\mathrm{Pt}, \mathrm{Au}, \mathrm{Tl}, \mathrm{Pb}, \mathrm{Th}, \mathrm{U})$. All geochemical analyses are contained in Table $\mathrm{II}$. Note that many elements show analytical concentrations below the detection limit.

\section{Isotope Paleothermometry:}

Paleothermometry analysis was conducted on fracture infill cements using conventional methods (Dipple and Ferry, 1992). Results indicate that all dolomite fracture cement samples (and the calcite sample) analyzed do not reflect cement precipitation under low-temperature, near-surface karst conditions (i.e. measured temperatures $>60$ degrees Celsius). Instead, it appears that most samples reflect the influence of deeper burial diagenesis under the influence of outside, deeper, more radiogenic fluids. Those samples possessing a $\delta^{18} \mathrm{O}$ of $-5(\mathrm{PDB})$ would be in equilibrium with SMOW at about 58 degrees Celsius. Those cements with a $\delta^{18} \mathrm{O}$ of -8 would equilibrate with SMOW at about 90 degrees Celsius. The latter event is much deeper than the former.

These results agree with those of Kupecz (1989, see Figure 28) who showed the areal distribution of carbonate matrix $\delta^{18} \mathrm{O}$ for the Ellenburger Group in West Texas. The majority of these matrix dolomite samples show temperatures in the 60 degree Celsius range.' The higher temperature samples observed in our study must reflect a deeper basin origin.

Given the close temporal correspondence between maximum burial and regional tectonism, we believe that these higher temperature samples indicate either: 1) the majority of karst-related fracturing was not fully healed until later burial and diagenesis, or 2) the majority of fractures are tectonic in origin. Given the fracture analysis based on petrographic analysis and mesoscopic studies, we believe that case 1 is the most likely. This is particularly appropriate given that many of the fractures appear synchronous with cement phases that outline adjacent karst breccia clasts.

\section{Geochemical Results:}

Preliminary and limited geochemical and isotopic results are consistent with nearly complete dolomite-replacement of an older limestone protolith by regional diagenetic fluids. In accordance with work by Kupecz (1989), diagenetic fluids became increasingly fluid-buffered over time and appear to be show a regional distribution consistent with expulsion and migration of warmer, more radiogenic 
fluids from the incoming Ouachita Mountain Front during the Pennsylvanian. Simultaneous with these more radiogeneic fluids, later fluids entering into the system appear to be enriched in metallic and siliceous phases. The final dolomite fracture cements and pyrite fracture cements are iron-rich and appear to represent one of the final cement phases. Most importantly, these cements infilled in both the remaining voids and open fractures in the older karst-related fracture sets and related breccias, and also filled in the tectonic fractures that formed during Pennsylvanian deformation and related diagenetic fluid migration.

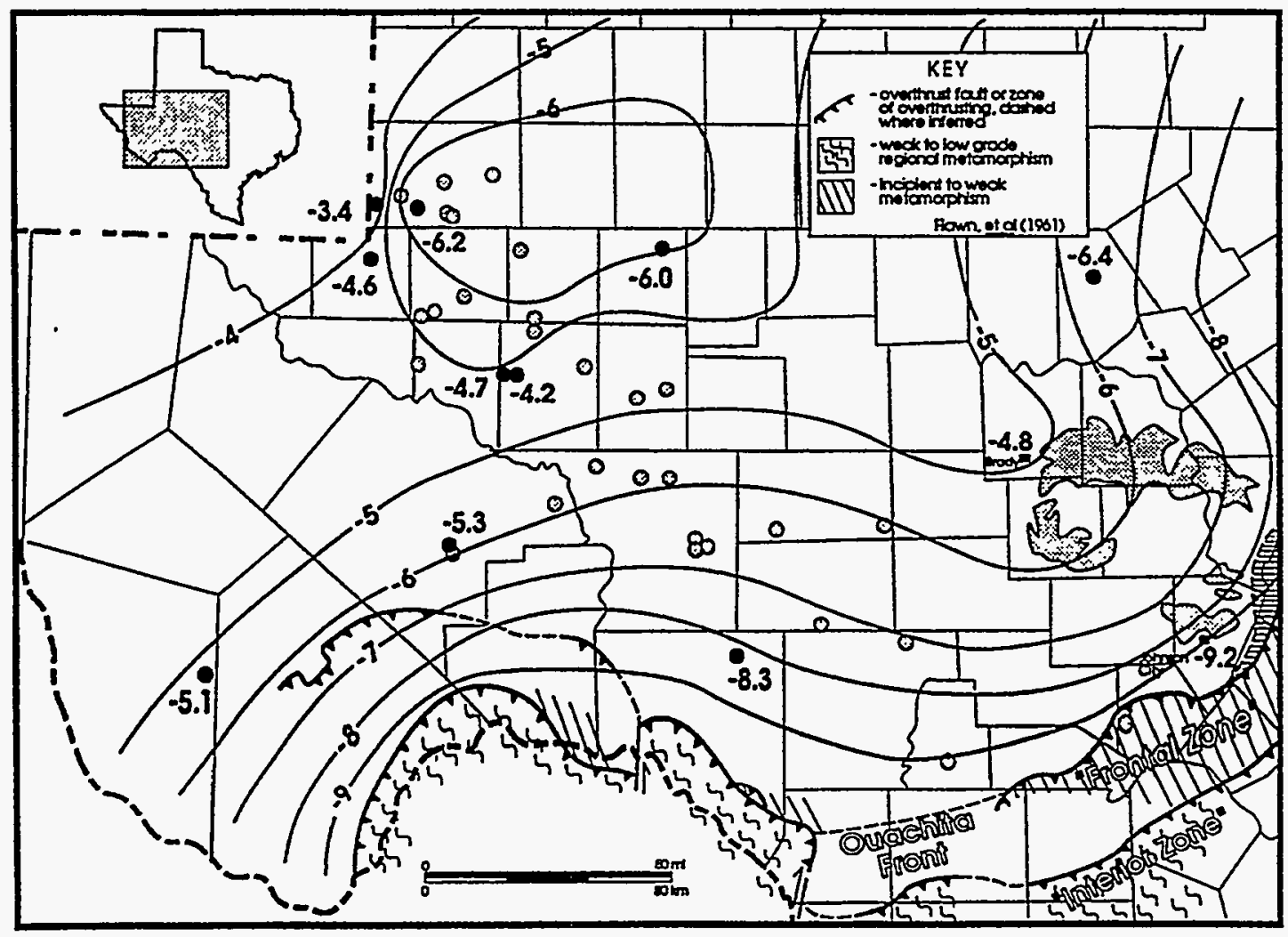

Figure 28: Contour map of $\delta^{18} \mathrm{O}$ values for late-stage replacement dolomite of $\mathrm{Kupecz}$ (1989). Note heaviest values found to the south, adjacent to the Ouachita orogenic front. The majority of fracture cement samples analyzed in this study show similar values $(\sim-6)$ indicating a post-karst origin influenced by regional fluid flow. 
TABLE II:

Phillips South Fault Block \#4-62 Geochemical Data

\begin{tabular}{|c|c|c|c|c|c|c|c|c|c|c|c|c|c|c|}
\hline SAMPLE ID & $\begin{array}{l}\text { Sample } \\
\text { Depth (ft.) }\end{array}$ & $\begin{array}{c}\text { Sample } \\
\text { composition }\end{array}$ & $\begin{array}{l}\delta^{13} \mathrm{C} \\
\mathrm{PDB}\end{array}$ & $\begin{array}{c}\delta^{18} O \\
\text { SMOW }\end{array}$ & $\begin{array}{l}\delta^{18} O \\
\text { PDB }\end{array}$ & $\underset{\text { (ppm) }}{\mathrm{Na}}$ & $\underset{(\mathrm{ppm})}{\mathbf{M g}}$ & $\underset{(p p m)}{A !}$ & $\underset{(p p m)}{\mathbf{S i}}$ & $\underset{(p p m)}{K}$ & $\underset{(\mathrm{ppm})}{\mathrm{Ca}}$ & $\begin{array}{c}\mathrm{Ti} \\
(\mathrm{ppm})\end{array}$ & $\underset{(p p m)}{V}$ & $\begin{array}{c}\text { Cr } \\
(\mathrm{ppm})\end{array}$ \\
\hline $80-01-1$ & 8376 & Dolomite & -1.40 & 26.20 & 26.20 & $290^{\circ}$ & 121000 & 282 & 2050 & $<580$ & 215000 & $449^{\circ}$ & 6.8 & 13.7 \\
\hline $80-01-4$ & 8072 & Dolomite & -1.40 & 25.40 & 25.40 & 509 & 126000 & 186 & 841 & $<580$ & 218000 & 16 & 8.4 & 11.6 \\
\hline $3280-01-5$ & 8079.8 & Dolomite & -1.70 & 25.90 & 25.90 & 518 & 124000 & 225 & 853 & $<580$ & 219000 & 14 & 9.6 & 2.4 \\
\hline $280-01-6$ & 8083 & Dol & -1.00 & 26.10 & 26.10 & 500 & 120000 & 1430 & 6300 & 2220 & 213000 & 103 & 13.2 & 12.5 \\
\hline $280-01-8$ & 8097.5 & Dol & -1.40 & 25.40 & 25.40 & 342 & 125000 & 182 & 2330 & $<580$ & 217000 & 17 & 11.2 & 3.3 \\
\hline GG-38280-01-9 & 8098 & Dolomite & -1.40 & 21.90 & 21.90 & $55^{\circ}$ & 108000 & 131 & 384 & $<580$ & 245000 & 10 & 1.9 & 3.9 \\
\hline $280-01-11$ & 8214 & Dol & -1.60 & 25.60 & 25.60 & 472 & 123000 & 326 & 8670 & 636 & 216000 & 18 & 10.5 & 8.2 \\
\hline SG & 8368 & nite & -1.50 & 25.40 & 25.40 & 803 & 126000 & 431 & 3010 & $<580$ & 217000 & 48 & 10.4 & 12.2 \\
\hline $3 G-3$ & 8375 & Dolomite & -1.90 & 25.00 & 25.00 & 471 & 120000 & 142 & 1130 & $<580$ & 230000 & 15 & 10.5 & 5.3 \\
\hline $01-2$ & 784 & Barit & & & & 445 & 96 & 262 & 1810 & $<580$ & $<480$ & 4 & 0.7 & 1.6 \\
\hline GG-38280-01-3 & $7853 . .8$ & Barile & & & & 222 & 587 & 169 & 582 & $<580$ & 979 & 122 & 0.2 & 6.7 \\
\hline GG-38280-01-7 & 8083.2 & Calcite & -3.20 & 23.50 & 23.50 & 44 & 1870 & 102 & 154 & $<580$ & 401000 & 7 & 2.0 & 2.1 \\
\hline $3 G-38280-01-10$ & 8192.8 & Quartz & & & & 262 & 160 & 1630 & 465000 & 582 & $<480$ & 84 & 2.0 & 6.0 \\
\hline
\end{tabular}


TABLE II:

Phillips South Fault Block \#4-62

Geochemical Data

\begin{tabular}{|c|c|c|c|c|c|c|c|c|c|c|c|c|}
\hline SAMPLE ID & $\begin{array}{l}\text { Sample } \\
\text { Depth (ft.) }\end{array}$ & $\begin{array}{c}\text { Sample } \\
\text { composition }\end{array}$ & $\underset{\text { (ppm) }}{\operatorname{Mn}}$ & $\begin{array}{c}\text { Fe } \\
(\mathrm{ppm})\end{array}$ & $\underset{\text { (ppm) }}{\mathrm{NI}}$ & $\underset{\text { (ppm) }}{\mathrm{Cu}}$ & $\underset{\text { (ppm) }}{\mathrm{Zn}}$ & $\begin{array}{c}\text { Ga } \\
(\mathrm{ppm})\end{array}$ & $\underset{(p p m)}{G e}$ & $\begin{array}{c}\text { As } \\
\text { (ppm) }\end{array}$ & $\begin{array}{c}\text { Se } \\
\text { (ppm) }\end{array}$ & $\begin{array}{c}\mathbf{R b} \\
\text { (ppm) }\end{array}$ \\
\hline GG-38280-01-1 & 8376 & Dolomite & 766 & 6010 & 463 & 10.0 & 38.2 & - & 0.5 & 0.6 & 3.9 & 0.5 \\
\hline GG-38280-01-4 & 8072 & Dolomile & 337 & 1570 & 128 & 6.5 & 30.1 & 2.4 & 0.1 & $<0.5$ & 5.9 & 0.3 \\
\hline GG-38280-01-5 & 8079.8 & Dolomite & 312 & 1900 & 7 & 10.3 & 90.5 & 2.1 & $<0.1$ & $<0.5$ & $<0.5$ & 0.2 \\
\hline GG-38280-01-6 & 8083 & Dolomite & 283 & 1670 & 17 & 6.0 & 32.4 & 6.5 & $<0.1$ & 0.5 & 0.5 & 3.5 \\
\hline GG-38280-01-8 & 8097.5 & Dolomite & 314 & 1340 & 8 & 19.3 & 39.5 & 1.4 & 0.3 & $<0.5$ & 2.8 & 0.4 \\
\hline GG-38280-01-9 & 8098 & Dolomite & 302 & 2880 & 71 & 9.1 & 52.2 & 1.9 & 0.1 & $<0.5$ & 1.5 & $<0.1$ \\
\hline $3 G-38280-01-11$ & 8214 & Dolomite & 431 & 2980 & 279 & 8.1 & 43.4 & 3.0 & 0.2 & $<0.5$ & 2.1 & 0.4 \\
\hline $3 G-38280-01-12$ & 8368 & Dolomite & 632 & 2160 & 74 & 21.2 & 143.0 & 1.5 & 0.2 & 1.7 & 1.3 & 0.7 \\
\hline SG-38280-01-13 & 8375 & Dolomile & 769 & 6110 & 56 & 9.7 & 34.8 & 1.1 & 0.2 & 0.9 & 3.4 & 0.2 \\
\hline GG-38280-01-2 & 7846 & Barite & 13 & 723 & 4 & 2.2 & - & - & 0.3 & $<0.5$ & 4.6 & 0.4 \\
\hline GG-38280-01-3 & $7853 . .8$ & Barite & 18 & 246 & 80 & 1.7 & - & - & $<0.1$ & $<0.5$ & 4.8 & 0.4 \\
\hline GG-38280-01-7 & 8083.2 & Calcite & 471 & 1130 & 7 & 6.3 & 23.5 & 0.4 & 1.3 & 1.0 & 3.3 & $<0.1$ \\
\hline $3 G-38280-01-10$ & 8192.8 & Quartz & 4 & 125 & 5 & 3.1 & 22.4 & 1.4 & 1.3 & $<0.5$ & 1.3 & 1.7 \\
\hline
\end{tabular}


TABLE II:

Phillips South Fault Block \#4-62

Geochemical Data

\begin{tabular}{|c|c|c|c|c|c|c|c|c|c|c|c|c|}
\hline SAMPLE ID & $\begin{array}{l}\text { Sample } \\
\text { Depth (ft.) }\end{array}$ & $\begin{array}{c}\text { Sample } \\
\text { composition }\end{array}$ & $\begin{array}{c}\mathrm{Sr} \\
(\mathrm{ppm})\end{array}$ & $\begin{array}{c}Y \\
(p p m)\end{array}$ & $\begin{array}{c}\mathbf{Z r} \\
(\mathrm{ppm})\end{array}$ & $\begin{array}{c}\text { Nb } \\
(p p m)\end{array}$ & $\begin{array}{c}\text { Mo } \\
\text { (ppm) }\end{array}$ & $\underset{(\mathbf{p p m})}{\mathbf{R u}}$ & $\begin{array}{c}\mathbf{R h} \\
(\mathrm{ppm})\end{array}$ & $\begin{array}{c}\text { Pd } \\
(\mathrm{ppm})\end{array}$ & $\underset{(p p m)}{\mathrm{Ag}}$ & $\underset{(p p m)}{C d}$ \\
\hline GG-38280-01-1 & 8376 & Dolomite & 182 & 16.3 & 50.0 & $<0.1$ & 2.7 & 0.1 & $<0.1$ & 0.1 & 0.6 & $<0.1$ \\
\hline GG-38280-01-4 & 8072 & Dolomite & 47 & 7.3 & 1.6 & $<0.1$ & 0.6 & 0.2 & $<0.1$ & $<0.1$ & $<0.1$ & 0.3 \\
\hline GG-38280-01-5 & 8079.8 & Dolomite & 49 & 12.1 & 4.7 & 0.1 & 0.5 & $<0.1$ & $<0.1$ & $<0.1$ & 0.1 & 0.1 \\
\hline GG-38280-01-6 & 8083 & Dolomite & 57 & 4.8 & 4.3 & 0.3 & 0.5 & $<0.1$ & $<0.1$ & 0.1 & $<0.1$ & 0.3 \\
\hline GG-38280-01-8 & 8097.5 & Dolomite & 41 & 11.0 & 2.5 & $<0.1$ & 0.3 & $<0.1$ & $<0.1$ & 0.1 & 0.2 & 0.1 \\
\hline GG-38280-01-9 & 8098 & Dolomite & 97 & 2.5 & 1.1 & $<0.1$ & 0.4 & $<0.1$ & $<0.1$ & $<0.1$ & 0.1 & $<0.1$ \\
\hline $3 G-38280-01-11$ & 8214 & Dolomite & 44 & 13.9 & 1.1 & 0.1 & 0.5 & $<0.1$ & $<0.1$ & $<0.1$ & $<0.1$ & 0.7 \\
\hline $3 G-38280-01-12$ & 8368 & Dolomite & 46 & 15.4 & 4.0 & 0.4 & 1.3 & $<0.1$ & $<0.1$ & 0.5 & 0.5 & 1.2 \\
\hline $3 G-38280-01-13$ & 8375 & Dolomite & 42 & 17.2 & 0.8 & $<0.1$ & 0.2 & $<0.1$ & $<0.1$ & 0.1 & 0.1 & 0.2 \\
\hline GG-38280-01-2 & 7846 & Barite & 55300 & 0.6 & 140.0 & $<0.1$ & 0.3 & 0.4 & 0.3 & 7.0 & 0.1 & 0.1 \\
\hline GG-38280-01-3 & 7853.8 & Barite & 55400 & 0.5 & 31.4 & $<0.1$ & 1.5 & 0.2 & 0.2 & 5.8 & $<0.1$ & 0.9 \\
\hline GG-38280-01-7 & 8083.2 & Calcite & 72 & 66.7 & 1.4 & 0.1 & 0.1 & $<0.1$ & $<0.1$ & 0.2 & $<0.1$ & 0.2 \\
\hline 3G-38280-01-10 & 8192.8 & Quartz & 2 & 0.2 & 1.4 & 0.3 & 0.3 & $<0.1$ & $<0.1$ & $<0.1$ & 0.1 & 0.1 \\
\hline
\end{tabular}


TABLE II:

Phillips South Fault Block \#4-62

Geochemical Data

\begin{tabular}{|c|c|c|c|c|c|c|c|c|c|c|c|c|c|}
\hline SAMPLE ID & $\begin{array}{l}\text { Sample } \\
\text { Depth (ft.) }\end{array}$ & $\begin{array}{c}\text { Sample } \\
\text { composition }\end{array}$ & $\underset{\text { (ppm) }}{\text { Sn }}$ & $\begin{array}{c}\text { Sb } \\
\text { (ppm) }\end{array}$ & $\begin{array}{c}\text { Te } \\
\text { (ppm) }\end{array}$ & $\begin{array}{c}\text { Cs } \\
(p p m)\end{array}$ & $\begin{array}{c}\mathbf{B a} \\
(\mathbf{p p m})\end{array}$ & $\underset{\text { (ppm) }}{\text { La }}$ & $\begin{array}{c}\text { Co } \\
\text { (ppm) }\end{array}$ & $\underset{(p p m)}{\mathrm{Pr}}$ & $\begin{array}{c}\text { Nd } \\
\text { (ppm) }\end{array}$ & $\underset{(p p m)}{S m}$ & $\begin{array}{c}\text { Eu } \\
(\mathbf{p p m})\end{array}$ \\
\hline GG-38280-01-1 & 8376 & Dolomite & 0.5 & 0.2 & 0.1 & $<0.1$ & 1670 & 6.0 & 15.4 & 2.1 & 8.6 & 2.1 & 0.4 \\
\hline GG-38280-01-4 & 8072 & Dolomite & 0.2 & 0.4 & 0.1 & 0.1 & 60 & 5.0 & 8.2 & 1.0 & 4.0 & 0.6 & 0.1 \\
\hline GG-38280-01-5 & 8079.8 & Dolomite & 0.3 & 0.3 & $<0.1$ & $<0.1$ & 16 & 6.1 & 13.5 & 1.8 & 6.3 & 1.5 & 0.3 \\
\hline GG-38280-01-6 & 8083 & Dolomite & 1.5 & 0.4 & $<0.1$ & 0.1 & 30 & 3.6 & 6.2 & 0.8 & 2.6 & 0.3 & 0.1 \\
\hline GG-38280-01-8 & 8097.5 & Dolomite & 0.2 & 0.9 & 0.1 & $<0.1$ & 15 & 5.8 & 12.3 & 1.6 & 5.6 & 1.3 & 0.2 \\
\hline GG-38280-01-9 & 8098 & Dolomite & $<0.1$ & 0.3 & $<0.1$ & 0.2 & 34 & 4.3 & 9.9 & 1.2 & 4.6 & 0.8 & 0.1 \\
\hline 3G-38280-01-11 & 8214 & Dolomite & 0.5 & 0.2 & $<0.1$ & 0.1 & 42 & 4.9 & 10.9 & 1.6 & 5.9 & 1.4 & 0.3 \\
\hline $3 G-38280-01-12$ & 8368 & Dolomite & 0.4 & 0.5 & $<0.1$ & 0.6 & 17 & 5.6 & 9.8 & 1.1 & 5.9 & 1.2 & 0.5 \\
\hline 3G-38280-01-13 & 8375 & Dolomite & 0.4 & 0.3 & $<0.1$ & $<0.1$ & 20 & 6.4 & 15.1 & 2.1 & 7.8 & 2.4 & 0.4 \\
\hline GG-38280-01-2 & 7846 & Barite & $<0.1$ & 0.3 & 0.1 & 0.1 & 502000 & - & 0.5 & 0.1 & - & - & - \\
\hline GG-38280-01-3 & $7853 . .8$ & Barite & 0.6 & 1.2 & $<0.1$ & 0.4 & 498000 & - & 0.2 & $<0.1$ & - & - & - \\
\hline GG-38280-01-7 & 8083.2 & Calcite & $<0.1$ & 0.6 & $<0.1$ & $<0.1$ & 4 & 25.0 & 85.9 & 13.0 & 48.0 & 13.8 & 2.5 \\
\hline $3 G-38280-01-10$ & 8192.8 & Quartz & 0.1 & 0.5 & $<0.1$ & 0.2 & 11 & 0.4 & 0.8 & 0.1 & 0.2 & 0.1 & $<0.1$ \\
\hline
\end{tabular}




\section{TABLE II:}

Phillips South Fault Block \#4-62

Geochemical Data

\begin{tabular}{|c|c|c|c|c|c|c|c|c|c|c|c|c|c|c|}
\hline SAMPLE ID & $\begin{array}{l}\text { Sample } \\
\text { Depth (ft.) }\end{array}$ & $\begin{array}{c}\text { Sample } \\
\text { composition }\end{array}$ & $\underset{(p p m)}{G d}$ & $\begin{array}{c}\text { Tb } \\
\text { (ppm) }\end{array}$ & $\begin{array}{c}\text { Dy } \\
\text { (ppm) }\end{array}$ & $\begin{array}{c}\text { Ho } \\
\text { (ppm) }\end{array}$ & $\underset{(p p m)}{E r}$ & $\underset{(p p m)}{T m}$ & $\begin{array}{c}\mathrm{Yb} \\
(\mathrm{ppm})\end{array}$ & $\begin{array}{c}\text { Lu } \\
\text { (ppm) }\end{array}$ & $\begin{array}{c}\text { HF } \\
(\mathrm{ppm})\end{array}$ & $\begin{array}{c}\mathrm{Ta} \\
\text { (ppm) }\end{array}$ & $\underset{\text { (ppm) }}{W}$ & $\underset{\text { (ppm) }}{\text { Re }}$ \\
\hline GG-38280-01-1 & 8376 & Dolomite & 2.4 & 0.5 & 2.6 & 0.6 & 1.6 & 0.2 & 1.3 & 0.3 & 1.1 & $<0.1$ & $<0.1$ & $<0.1$ \\
\hline GG-38280-01-4 & 8072 & Dolomite & 0.7 & 0.1 & 0.7 & 0.3 & 0.7 & $<0.1$ & 0.5 & 0.1 & $<0.1$ & $<0.1$ & $<0.1$ & 0.1 \\
\hline GG-38280-01-5 & 8079.8 & Dolomite & 1.7 & 0.3 & 1.8 & 0.5 & 1.2 & 0.2 & 1.2 & 0.2 & $<0.1$ & $<0.1$ & $<0.1$ & $<0.1$ \\
\hline GG-38280-01-6 & 8083 & Dolomite & 0.5 & 0.1 & 0.6 & 0.2 & 0.4 & 0.1 & 0.2 & 0.1 & 0.1 & $<0.1$ & 4.9 & $=0$ \\
\hline GG-38280-01-8 & 8097.5 & Dolomite & 1.3 & 0.3 & 1.6 & 0.4 & 1.1 & 0.2 & 1. & 0.2 & 0.1 & $<0.1$ & $<0.1$ & $<0$. \\
\hline GG-38280-01-9 & 8098 & Dolomite & 0.7 & 0.1 & 0.6 & 0.1 & 0.2 & $<0.1$ & 0.1 & $<0.1$ & $<0.1$ & $<0.1$ & $<0.1$ & $<0.1$ \\
\hline 3G-38280-01-11 & 8214 & Dolomite & 1.7 & 0.4 & 2.3 & 0.5 & 1.4 & 0.2 & 1.3 & 0.2 & $<0.1$ & $<0.1$ & $<0.1$ & $<0.1$ \\
\hline 3G-38280-01-12 & 8368 & Dolomite & 1.7 & 0.3 & 2.5 & 0.5 & 1.3 & 0.2 & 1.4 & 0.3 & 0.3 & 0.1 & 0.3 & $<0$ \\
\hline $3 G-38280-01-13$ & 8375 & Dolomite & 2.5 & 0.5 & 2.6 & 0.6 & 1.7 & 0.2 & 1.3 & 0.2 & 0.1 & $<0.1$ & 0.1 & $<0$. \\
\hline $\begin{array}{l}\text { GG-38280-01-2 } \\
\text { GG-38280-01-3 }\end{array}$ & $\begin{array}{c}7846 \\
7853 . .8\end{array}$ & $\begin{array}{l}\text { Barite } \\
\text { Barite }\end{array}$ & $\begin{array}{c}<0.1 \\
0.1\end{array}$ & $\begin{array}{l}<0.1 \\
<0.1\end{array}$ & $\begin{array}{r}0.1 \\
<0.1\end{array}$ & $\begin{array}{r}0.1 \\
<0.1\end{array}$ & $\begin{array}{c}<0.1 \\
0.1\end{array}$ & $\begin{array}{l}<0.1 \\
<0.1\end{array}$ & $\begin{array}{r}0.1 \\
<0.1\end{array}$ & $\begin{array}{l}<0.1 \\
<0.1\end{array}$ & 3.6 & 0. & $\begin{array}{c}<0.1 \\
0.2\end{array}$ & $<0$ \\
\hline GG-38280-01-7 & 8083.2 & Calcite & 13.0 & 2.5 & 12.0 & 2.4 & 5.8 & 0.9 & 5.2 & 0.7 & $<0.1$ & $<0.1$ & $\begin{array}{l}0.2 \\
0.1\end{array}$ & $<0$. \\
\hline 3G-38280-01-10 & 8192.8 & Quartz & $<0.1$ & $<0.1$ & $<0.1$ & $<0.1$ & $<0.1$ & $<0.1$ & $<0.1$ & $<0.1$ & 0.1 & $<0.1$ & 0.1 & $<0$ \\
\hline
\end{tabular}


TABLE II:

Phillips South Fault Block \#4-62

Geochemical Data

\begin{tabular}{|c|c|c|c|c|c|c|c|c|c|c|c|c|}
\hline SAMPLE ID & $\begin{array}{l}\text { Sample } \\
\text { Depth (ft.) }\end{array}$ & $\begin{array}{c}\text { Sample } \\
\text { composition }\end{array}$ & $\underset{(p p m)}{\text { Os }}$ & $\underset{(p p m)}{I r}$ & $\begin{array}{c}\text { Pt } \\
\text { (ppm) }\end{array}$ & $\underset{\text { (ppm) }}{\text { Au }}$ & $\underset{(\mathrm{ppm})}{\mathrm{TI}}$ & $\begin{array}{c}\mathbf{P b} \\
\text { (ppm) }\end{array}$ & $\begin{array}{c}\text { Th } \\
\text { (ppm) }\end{array}$ & $\underset{(p p m)}{U}$ & Sr-87/Sr-86 & $\begin{array}{c}\text { Sr-87/Sr-86 } \\
\text { (+/- est error) }\end{array}$ \\
\hline GG-38280-01-1 & 8376 & Dolomite & $<0.1$ & 0.1 & 0.1 & $<0.1$ & $<0.1$ & 5.9 & 0.1 & 0.3 & 0.711 & 0.020 \\
\hline SG-38280-01-4 & 8072 & Dolomite & 0.1 & $<0.1$ & 0.1 & $<0.1$ & $<0.1$ & 2.3 & $<0.1$ & 0.2 & 0.691 & 0.020 \\
\hline GG-38280-01-5 & 8079.8 & Dolomite & $<0.1$ & $<0.1$ & $<0.1$ & $<0.1$ & 0.1 & 12.7 & 0.1 & 0.3 & 0.695 & 0.020 \\
\hline GG-38280-01-6 & 8083 & Dolomite & $<0.1$ & $<0.1$ & $<0.1$ & $<0.1$ & $<0.1$ & 3.3 & 0.1 & 0.6 & 0.683 & 0.020 \\
\hline GG-38280-01-8 & 8097.5 & Dolomite & $<0.1$ & $<0.1$ & $<0.1$ & $<0.1$ & $<0.1$ & 3.0 & $<0.1$ & 0.5 & 0.678 & 0.020 \\
\hline GG-38280-01-9 & 8098 & Dolomite & $<0.1$ & $<0.1$ & $<0.1$ & $<0.1$ & $<0.1$ & 2.3 & 0.1 & $<0.1$ & 0.724 & 0.020 \\
\hline G-38280-01-11 & 8214 & Dolomite & $<0.1$ & $<0.1$ & $<0.1$ & $<0.1$ & $<0.1$ & 2.1 & $<0.1$ & 0.2 & 0.726 & 0.020 \\
\hline G-38280-01-12 & 8368 & Dolomite & 0.1 & $<0.1$ & $<0.1$ & $<0.1$ & $<0.1$ & 6.7 & 0.2 & 0.2 & 0.729 & 0.020 \\
\hline $80-01-13$ & 8375 & Dolomite & $<0.1$ & $<0.1$ & $<0.1$ & $<0.1$ & $<0.1$ & 12.4 & $<0.1$ & 0.2 & 0.668 & 0.020 \\
\hline 2 & 7846 & Barite & $<0.1$ & $<0.1$ & 0.1 & $<0.1$ & $<0.1$ & 0.1 & 0.1 & 0.2 & 0.716 & 0.020 \\
\hline G-38280-01-3 & $7853 . .8$ & Barite & 0.1 & $<0.1$ & $<0.1$ & $<0.1$ & 0.1 & $<0.1$ & 0.1 & $<0.1$ & 0.717 & 0.020 \\
\hline G-38280-01-7 & 8083.2 & Calcite & $<0.1$ & $<0.1$ & $<0.1$ & $<0.1$ & $<0.1$ & 1.8 & $<0.1$ & $<0.1$ & 0.688 & 0.020 \\
\hline G-38280-01-10 & 8192.8 & Quartz & $<0.1$ & $<0.1$ & $<0.1$ & $<0.1$ & $<0.1$ & 1.2 & 0.2 & 0.5 & & \\
\hline
\end{tabular}




\section{MODEL FOR FRACTURED RESERVOIR DEVELOPMENT}

Through integration of all available data, we have developed a model for Ellenburger Group fracture genesis and reservoir development. We have attempted to develop the model around the data and interpretations for the South Fault Block (SFBU) \#4-62 well but have attempted to integrate regional data in order to create a more generic, inclusive model for similar karsted-tectonic fractured reservoirs around the globe.

\section{Deposition and Karstification}

Initial deposition of the Ellenburger Group followed well-constrained models developed by Loucks and Anderson (1985) and expanded by Kerans (1990). Karstification processes controlled by eustatic sea level fall followed pre-existing basement anisotropy trends and created preferential dissolution pathways along these underlying structures. Development of collapse breccias and related karst features are preferentially developed along these basement anisotropy zones. The ability to predict the orientation and relative importance of these zones to later karst activity may be possible using calibrated seismic signatures and/or high-resolution magnetic surveys to assess basement structural controls on karst systems. Limited diagenesis occurred during this time frame and should reflect lowtemperature processes. Figure 29-a outlines the evolution of this time period.

\section{Burial and Karst Modification}

Burial of the karst system caused collapse of the karst caverns and the widespread development of roof, collapse and floor breccias following the models of Kerans (1990), and Loucks and Handford (1992). The schematic diagram in Figure 29-b outlines the evolution during this time period. As the system experiences progressive burial, the strength of the cavern roof is unable to withstand the overburden stress and the cavern collapses. Because of the low confining stress and overall low differential stress of the system, many of these karst-related fractures will not possess a systematic orientation. As a result, fractures should form in nearly every compass direction and possess a wide range of fracture dip angles. As deeper burial occurs, diagenetic fluids commence alteration of the primary rock fabrics and cementation of the breccia system occurs. The majority of these collapsed karst systems will be condensed into flattened elliptical chambers (in cross-section) possessing a third (and longest) dimension parallel to any subsurface fluvial system and/or any structural anisotropy beneath the system, for a general model involving phreatic/fluvial processes (e.g. general model; .Mazzullo and Chilingarian, 1998), or the overall geometry may be more circular in plan view if the controlling karst system is dominated by a meteoric/marine system (e.g. Caribbean Model; Mazzullo and Chilingarian, 1998). A comparison of the two types is shown in the following table (Table III).

\section{Tectonic Modification of Karst System during Regional Deformation}

During the Pennsylvanian-age Ouachita Orogeny, tectonic influences were exerted on the system. At this time, the Andector Field Anticline and related structures in West Texas were formed adjacent to pre-existing Precambrian-age basement structures that were apparently reactivated during Pennsylvanian-age contraction as high-angle reverse faults. These high-angle basement faults formed the asymmetric verging folds along the margins of the Central Basin Platform Uplift. Folding and related faulting caused the formation of tectonic fractures that crosscut the karst breccias and related karst diagenetic fabrics. Most of the tectonic fractures will be controlled by the regional stress state and should show a preferred orientation relative to the maximum horizontal compressive stress. Most importantly, these fractures should be high-angle and possess distinct orientation trends. The orientation of these fractures relative to adjacent faults and flexures will be dominated by adjacent fault trends. This greatly simplifies interpretation and prediction of subsurface fracture orientations. 


\section{Table III: Characteristics of Karst diagenesis}

Caribbean Model:

Short exposure time

Unstable carbonate mineralogy

Shallow burial

Minor tectonics

Minor deep phreatic zone

Primary and fabric-selective pore types dominate

Found only in tropical and semi-arid environments

Diffuse recharge-diffuse flow only

Affected by marine water mixing zone

Absence of hydrothermal mixing
General Model:

Longer exposure time

Stable mineralogy (calcite, dolomite)

Deep burial

One or several tectonic events

Important deep phreatic zone

Secondary and fracture porosities dominate

Wider range of environments

Confluent recharge, pipe and confined flow

Absence of marine mixing zone effects

Presence of hydrothermal mixing

(from Mazzullo and Chilingarian, 1998)

From independent assessments of regional shortening accommodation mechanisms (Hoak et al., 1998), we know that the majority of regional shortening is accommodated by faulting, not flexure or folding. This is also confirmed by analyses of maximum flow rates from within Andector Field (See paper by Sundberg et al. included in this report) that indicate greater maximum flow rates in lease blocks adjacent to fault zones. These areas show greater flow rates per reservoir volume than do axial or crestal areas of the structure where fold or flexure-related fracturing is generally most intense. Additional support for this interpretation is provided by core analysis and petrographic work by Prezbindowski . (1988, internal Phillips Company Report) who found that the best reservoir porosity and permeability was found in rubble zones probably related to mesoscopic faults observed in seismic data through the field. Detailed analysis of these rubble zones, however, did not reveal significant evidence (e.g. slickensided surfaces) of shear displacement in these rubble zones. It is likely that the brittle nature of the Ellenburger enhances the formation of brecciation or cataclastic shear zones instead of the formation of discrete shear surfaces. During this time frame, diagenetic fluids modified by deeper, higher temperature fluids (basement sourced?) infiltrated the system, cemented many of the karst breccias and related karst-produced fractures, and cemented many of the tectonic fractures that formed during the deformation. Figure 29-c outlines the evolution of this time period. 


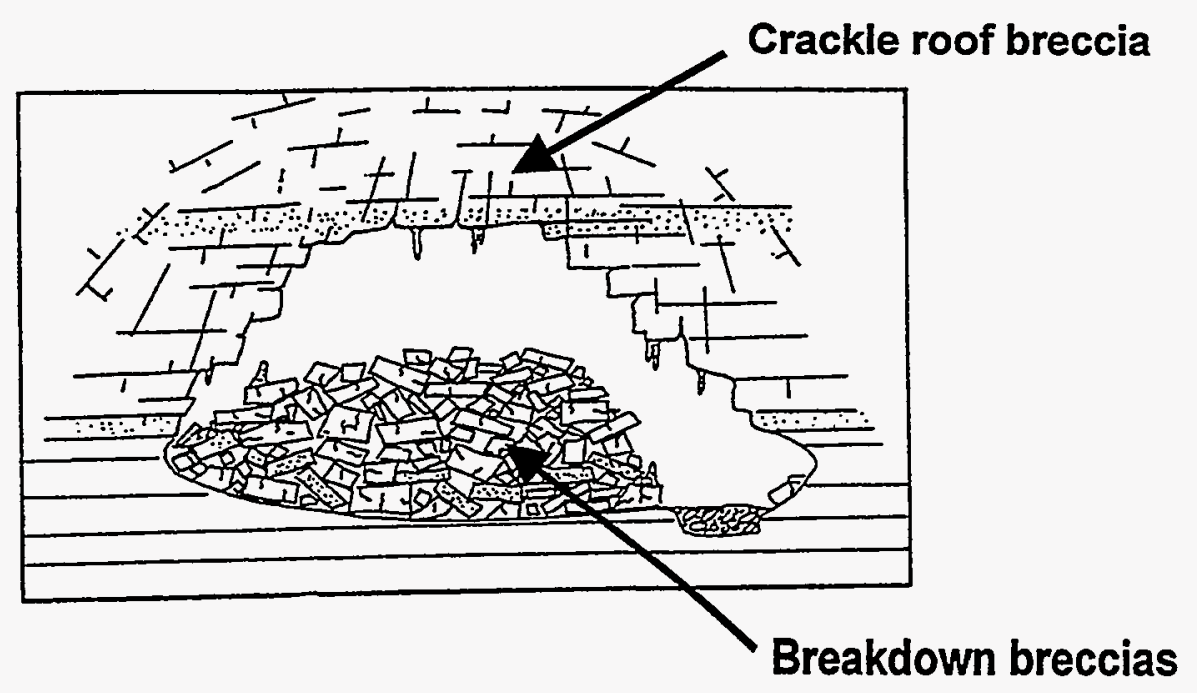

\section{system experiences burial...}

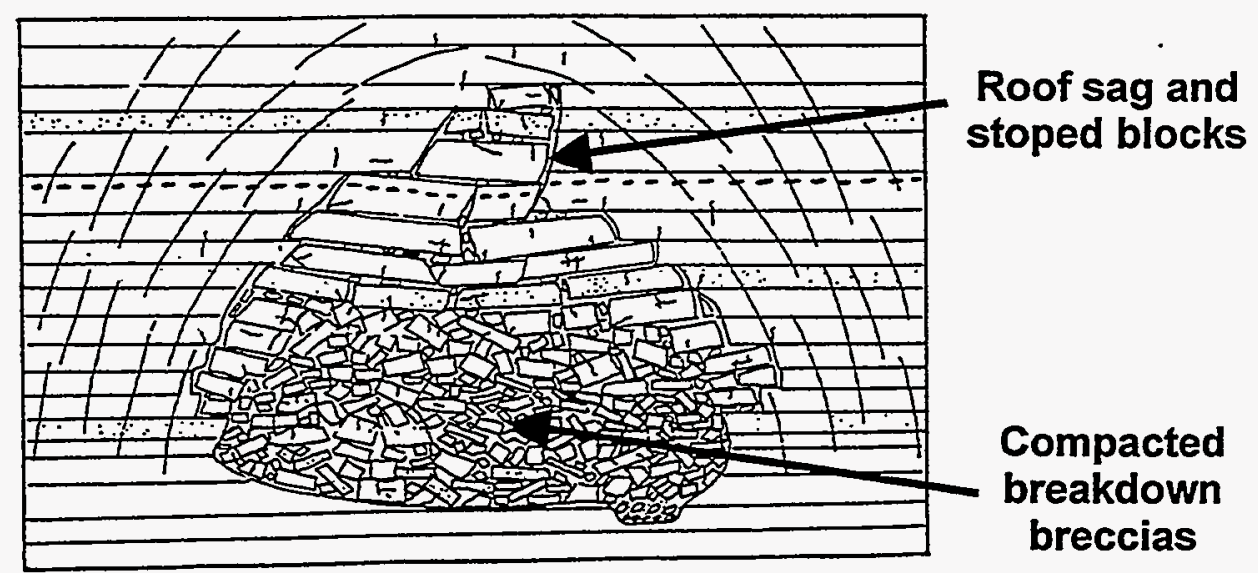

Figure 29 A: Initial development of karst system and related breccia caused by collapse of overlying roof into dissolution void.

Subsequent burial causes the breccia to experience clast-size reduction as overlying sediments drape down into sag. Allochthonous material may infill the cavern and form a matrix for the karst breccia, depending on local depositional system. Modifed after Loucks and Handford (1992). 


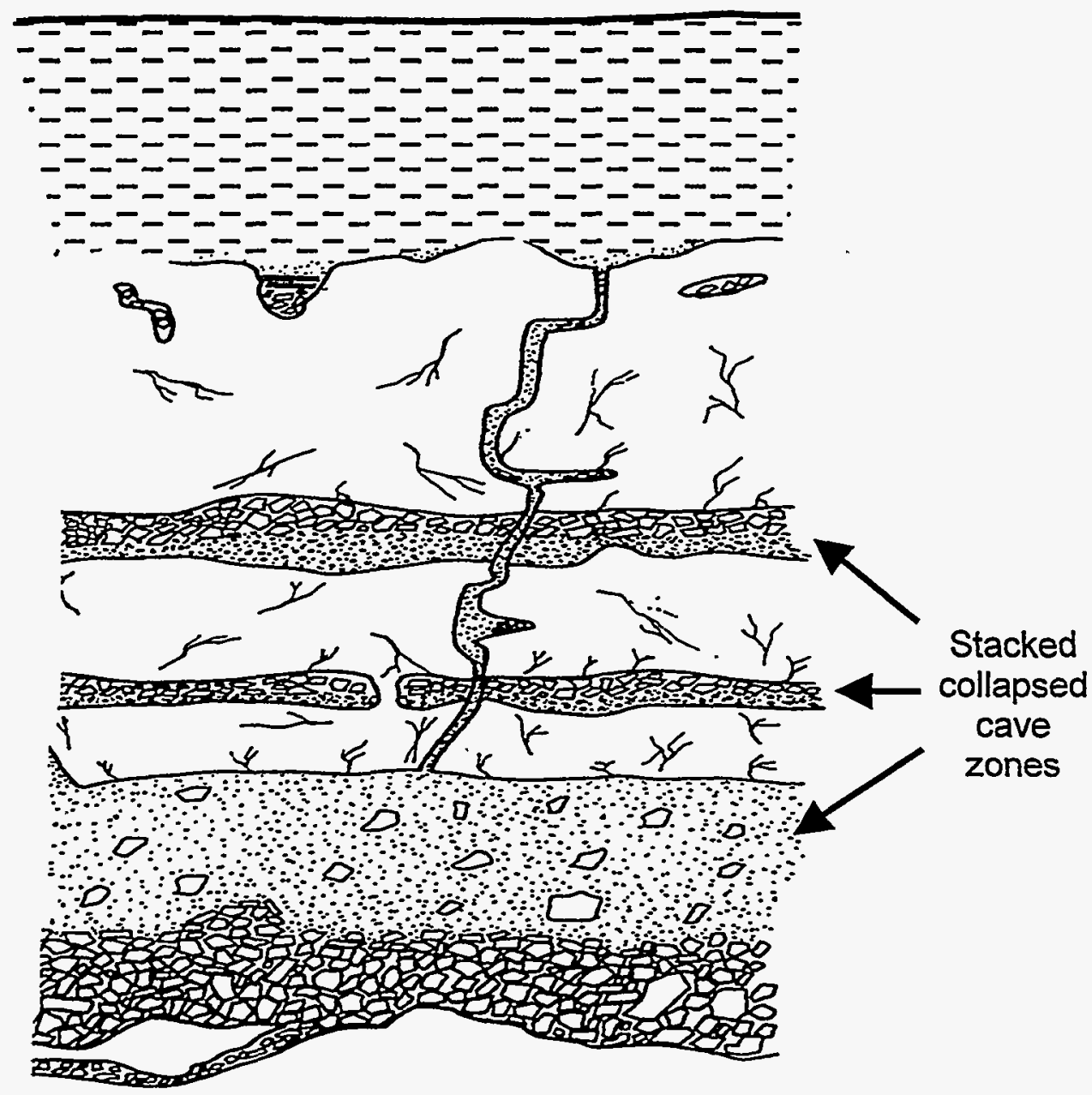

Figure $29 \mathrm{~B}$ : System has experienced burial to maximum depth and is composed of stacked karst zones showing a distinct gradation in sorting of blocks. Depending on amount of allochthonous material and diagenetic overprint, preserved porosity and permeability may remain high. There appears to be limited vertical connectivity of the karst zones although horizontal zones are likely well-connected. Modifed after Loucks and Handford (1992). 


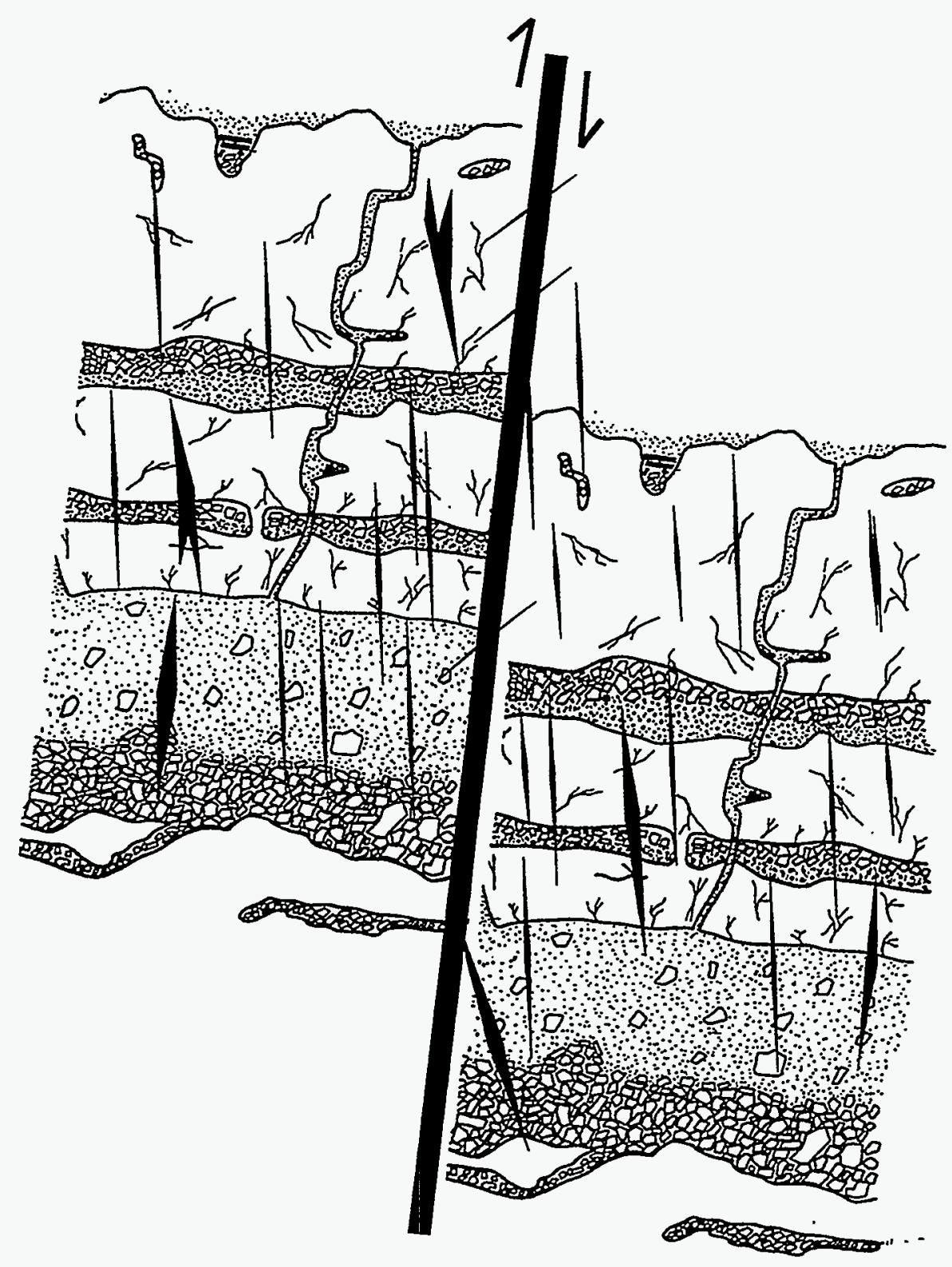

Figure 29 C: Karst system experiences tectonic deformation along high-angle reverse faults which form local structures and intense fractures adjacent to fault systems. Additional fractures are formed via flexure in tectonic folds. Tectonic fractures likely preferentially form in more rigid lithologies (e.g. pillars between karst caverns) so they enhance connectivity of the reservoir by linking the dominantly' horizontal flow units of the karst system. Modifed after Loucks and Handford (1992). 


\section{Conclusions \& Implications for Exploration and Development Programs}

The key to understanding the timing of natural fractures in the Ellenburger is to link the diagenetic history with the depositional, karst and tectonic history. From this perspective, a distinction can be made between tectonic and karst-related fractures. Geochemical analysis (e.g. ${ }^{87} \mathrm{Sr} /{ }^{86} \mathrm{Sr}, \delta^{18} \mathrm{O}$, major and trace element geochemistry) of dolomite-infilled fractures permits the refinement of the two data sets and discrimination between the two processes. A relatively quick, simple method that appears to work in many cored wells studied to date from throughout West Texas is whether the fracture crosscuts late, coarsely crystalline dolomite, and whether Fe-rich cements and or pyrite encrust or infill the fracture. We estimate that approximately $50 \%$ of all fractures analyzed in the Phillips- SFBU \#4-62 formed as a result of karst processes. However, in areas adjacent to faults, we believe that the importance of karst fracturing is significantly reduced. Work in progress is attempting to quantify these relationships.

There are numerous implications of the research results for exploration and development programs in similar carbonate reservoirs that have experienced karstification with superimposed tectonic deformation. Many of these findings are relevant to not only the Ellenburger Group, but to any other carbonate system that has experienced a period of subaerial exposure and fabric modification prior to tectonic deformation. We have broken these findings down into region-specific and non-specific results.

\section{West Texas Ellenburger Group:}

The Phillips SFBU \#4-62 does not show an upper karst breccia zone as would be suggested from a regional subaerial exposure event in late Ordovician time. Such an upper zone is found, however, in the nearby Phillips Embar 118 well. However, both the SFBU \#4-62 and Embar 118 well do show multiple stacked karst breccia zones. As a result, it is necessary to fully delineate the geometry of a potential drilling target (using 3D seismic) because of locally complex structural and depositional (e.g. karst) processes that may influence completion strategies.

A critical aspect of the model is the relative timing of hydrocarbon migration relative to the precipitation of the different diagenetic and fracture cement phases. A careful study of fracture cements should be undertaken to delineate the presence and characteristics of hydrocarbon inclusions related to the different fracture cement phases. This information would further refine the maturation, migration, entrapment history and will permit additional insight into the major migration pathways.

In the Ellenburger Group, the majority of fractures are caused by karst processes. Tectonic deformation appears to be most intense in areas adjacent to fault zones and flexure related fracturing is less common than the other two mechanisms. Most tectonic fractures appear to be thinner and longer than adjacent karst-related fractures. As a result, tectonic fractures likely link up isolated karst-related zones and provide critical reservoir connectivity that may be lacking in stratified karst breccia deposits. Also, in areas where the karst breccias is sediment-dominated and locally low-permeability, tectonic fractures may provide the only reservoir quality permeability. These relationships suggest the importance of delineating structural features, especially in the basement, that control and enhance the development of karst systems. Also, it underscores the need to fully assess the fracture mechanism, given the well-documented influence of both karst and tectonic processes. Failure to consider either mechanism underestimates reservoir quality and connectivity of the karst systems. 
In production trend analyses of the Andector Field, it appears that the greatest flow rates per reservoir volume are observed adjacent to fault zones. These observations indicate that the karst system is restricted in areal extent and that tectonic fractures are probably more common in fault-zone adjacent areas, in contrast to the structural culmination cored in the Phillips SFBU \#4-62. Additional core data should be analyzed in regions adjacent to fault zones to compare the relative abundance of tectonic (fault) vs. karst-related fracturing in these areas.

Over $85 \%$ of all natural fractures in the Phillips SFBU \#4-62 well (karst-related and tectonic) are tightly cemented. In general, dolomite and pyrite cemented fractures show the greatest effective aperture although there is a wide range of fracture occlusion for all data sets. This cement significantly degrades reservoir quality. Note that fractures in the basement rocks do not show mineralization. This suggests that this basement rock may be highly conductive and significant oil may be present in overlying coarse clastic rocks possessing adequate reservoir quality where deeper oil has migrated upward along the basement fractures and become trapped beneath the basal Ellenburger seal.

Karst-related fractures tend to be wider, shorter and more completely mineralized with either calcite or dolomite cements. They also tend to have lower dip angles and/or subhorizontal orientations and a wide range of azimuthal orientations. Tectonic fractures are narrower, longer, less completely mineralized or unmineralized, tend to be high-angle and display several preferred orientations (NW, NE and N/S). Drilling-induced fractures are rare, especially compared to the occurrence of such fractures in clastic systems. Given the highly fractured nature of the Ellenburger by karst and tectonic processes, it is possible that many drilling induced fractures propagate along natural surfaces and/or are arrested at abundant breccia zones where core recovery is poor.

Most fractures possess a high dip angle, especially in basement rocks underlying the Ellenburger. There appear to be two primary tectonic fracture trends, NW and NE. The NW-trending fracture set is most dominant and trends parallel to the axis of the local anticline that forms the field.

There is a limited range of length and width distributions for all fractures observed in Ellenburger cored wells. Given core sampling limitations, fracture length/width ratios tend to average around 100:1 for all fracture infill mineralogies (calcite, dolomite, clay, pyrite, quartz, anhydrite). Other wells from throughout the region show a similar limited range of fracture width distributions.

There appears to be an Ellenburger reservoir zonation found in Andector Field in which distinct fracture mineralization is restricted to certain reservoir intervals. Anhydrite mineralized fractures are restricted to the shallowest part of the reservoir. Calcite appears to show similar restrictions. Dolomite mineralized fractures are common throughout the reservoir while pyrite and quartz are found in the deepest part of the reservoir. It is possible that this implies limited downward circulation of sulfatebearing formation waters, and restricted upward migration of deeper subsurface fluids containing dissolved silica and metals. This may also indicate that there is a hydrodynamic boundary (lateral seal) within the Ellenburger reservoir. Reservoir production data, however, suggest that such a seal has not influenced hydrocarbon production.

Approximately $30 \%$ of all natural fractures have oil-staining in them. Of these, $9 \%$ of the quartz mineralized, $7 \%$ of the calcite mineralized, and $7 \%$ of the pyrite mineralized fractures show oil staining. In contrast, $50 \%$ of the clay mineralized, $51 \%$ of the dolomite mineralized, and $80 \%$ of the anhydrite mineralized fractures show oil staining. This information, coupled with the orientation of the majority of these different fracture sets relative to the orientation of the modern maximum horizontal stress (interpreted to be oriented at 103 degrees from analysis of anelastic strain recovery data and borehole 
imagery logs of drilling induced fractures), allows us to assess which fracture sets are most important to reservoir quality. From this analysis, anhydrite-mineralized fractures oriented orthogonal to this stress orientation are non-conductive and do not show oil-staining. Similarly, NNW-trending calcitemineralized fractures are not oil-stained and are non-conductive. N/S-trending clay-mineralized fractures are non-conductive as are most dolomite-mineralized fractures oriented at high angles to the maximum horizontal stress. The key to producing these reservoirs is to evaluate the geometry of the tectonic fractures and the extent of their mineral infill relative to the dynamics of the local and regional stress state.

Other public domain cores studied from throughout the region suggest that there are significant differences in natural fracture intensity with depth. These wells demonstrate that there are additional significant karst-related breccia zones present in the deeper Ellenburger. That is, below the upper 350 feet that has long been targeted and produced during the evolution of the play. These zones should be actively targeted and exploited, and deeper untested zones in the Ellenburger should be reassessed for bypassed reserves.

\section{Global Implications:}

One of the major findings of this project, in conjunction with other regional syntheses of karst terranes, is the observation that most carbonate rocks that have experienced a fall in base level and/or uplift of the carbonate terrane will show evidence of subaerial exposure and related permeability enhancement. In areas where conventional fractured reservoir analyses will be performed emphasizing structural analysis and structural traps, it is important to realize the potential for high permeability horizontal and subhorizontal zones caused by karstification. In addition, criteria developed in this project to distinguish between tectonic and karst breccias should be used to avoid potential problems in interpretation.

Given the apparent relationship between the development of karst and pre-existing structural anisotropies in the underlying stratigraphy, interpretation of low-cost gravity and aeromagnetic data may provide information to use to delineate anisotropy trends and refine zones of enhanced karst development. These trends can then be further investigated using seismic methods. 


\section{REFERENCES:}

Barnes, V.E., Cloud, P.E., Dixon, L.P., Folk, R.L., Jonas, E.C., Palmer, A.R., and Tynan, E.J., 1959, Stratigraphy of the pre-Simpson Paleozoic Subsurface Rocks of Texas and southeast New Mexico, University of Texas at Austin, Bureau of Economic Geology Publication 5924, 2 volumes, $836 \mathrm{p}$.

Dipple, G.M., and Ferry, J.M., 1992, Fluid flow and stable isotopic alterations in rocks at elevated temperature with applications to metamorphism, Geochimica Cosmochimica Acta, 56, 35393550 .

Galloway, W.E., Ewing, T.E., Garrett, C.M., Tyler, N. and Bebout, D.G., 1983, Atlas of Major Texas Oil Reservoirs, , The University of Texas at Austin, Bureau of Economic Geology Publication, 139 p.

Hoak, T.E., Sundberg, K.S., Ortoleva, P. and Shebl, M., 1998, Discrimination Between Karst and Tectonic Fractures in the Ellenburger Formation, West Texas: Implications for Exploration Models, American Association of Petroleum Geologists Poster Session abstract, American Association of Petroleum Geologists Annual Meeting, Salt Lake City, UT.

Hoak, T.E., Sundberg, K.S., and Ortoleva, P., 1998, Calculation and Interpretation of Crustal Shortening Along the Central Basin Platform, West Texas: A New Method to Identify Subsurface Fault Zones, American Association of Petroleum Geologists Poster Session abstract, American Association of Petroleum Geologists Annual Meeting, Salt Lake City, UT.

Hoak, T.E., Sundberg, K.S., Ortoleva, P. and Shebl, M., 1997, Structural Synthesis and Tectonic Interpretation for an Integrated Modeling Study of Ellenburger and Clear Fork Reservoirs, Permian Basin, West Texas, paper to be published in West Texas Geological Society proceedings from American Association of Petroleum Geologists -Southwest Section Meeting, held in San Angelo, Texas, June, 1997.

Ijirigho, B.T., and Schreiber, J.G., 1986, Origin and classification of fractures and related breccias in the Lower Ordovician Ellenburger Group, West Texas, West Texas Geological Society Bulletin, 26, 915.

Katz , B.J., Robison, V.D., Dawson, W.C., and Elrod, L.W.,1994, Simpson-Ellenburger(.) Petroleum System of the Central Basin Platform, West Texas, U.S.A., in: Magoon, L.B. and Dow. W.G., eds., The Petroleum System-From Source to Trap, American Association of Petroleum Geologists Memoir 60, 453-461, AAPG, Tulsa.

Kerans, C., 1988, Karst-controlled reservoir heterogeneity and an example from the Ellenburger Group (Lower Ordovician) of West Texas, Bureau of Economic Geology Report of Investigations No. $186,40 \mathrm{p}$.

Kerans, C., 1990, Depositional Systems and Karst Geology of the Ellenburger Group (Lower Ordovician), Subsurface West Texas, University of Texas at Austin Bureau of Economic Geology, Report of Investigations no. $193,61 \mathrm{p}$. 
Kupecz, J.A., 1989, Petrographic and Geochemical Characterization of the Lower Ordovician Ellenburger Group, West Texas, unpublished $\mathrm{Ph}$.D. dissertation, The University of Texas at Austin, $158 \mathrm{p}$.

Loucks, R.G., and Anderson, J.H., 1985, Depositional Facies, Diagenetic Terranes, and Porosity Development in Lower Ordovician Ellenburger Dolomite, Puckett Field, West Texas, In: Roehl, P.O., and Choquette, P.W., eds., Carbonate Petroleum Reservoirs, Springer-Verlag, 19-38.

Loucks, R.G., and Handford, C.R, 1992, Origin and Recognition of fractures, breccias, and sediment fills

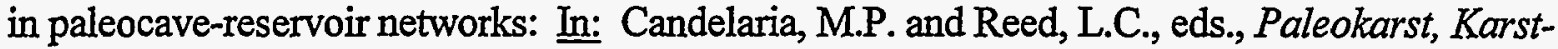
related diagenesis and reservoir development,: Examples from Ordovician-Devonian-age Strata of West Texas and the Mid-Continent, Permian Basin, SEPM 1992 Annual Field Trip, Franklin Mountains, El Paso, Texas, April 9-11, 1992, 31-44.

Loucks, R.G. and Mescher, P.K., 1997, Interwell Scale Architecture, Heterogeneity, and pore-network development in paleocave reservoirs, Guidebook to AAPG Field Trip, AAPG Annual Meeting, Dallas, TX, April 9-11, 1997.

Mazzullo, S. J., and Chilingarian, G.V., 1996, Hydrocarbon Reservoirs in Karsted Carbonate Rocks, eds., G.V. Chilingarian, S.J. Mazzullo, and H.H. Reike, Carbonate Reservoir Characterization: A Geologic-Engineering Analysis. Part II, Elsevier, New York, 797-865, .

Moore, W.D., Truby, L.G., 1952, The pressure performance of five fields completed in a common aquifer, Transactions AIME , 238-G, 195, 8 pgs.

Prezbindowski, D.R., 1989, Sedimentology and Petrology of Core Material from the 7760-8520 Foot Interval of the Phillips South Fault Block \#4-62 Well, Ector County, Texas, Unpublished Phillips Oil Company Internal Report, approx. 60 p.

Prezbindowski, D.R., and Siemers, W.T.,1991, Petrology and Reservoir Characterization of the Ellenburger Formation: University \#118 Well, Embar Field, Andrews County, Texas, Unpublished Phillips Oil Company Internal Report, approx. $56 \mathrm{p}$.

Rhett, D.W. and Teufel, L.W., 1998, Borehole Stability Analysis of a Horizontal Well in Fractured

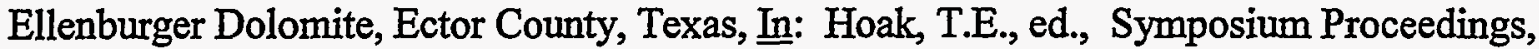
Rocky Mountain Association of Geologists, Fractured Reservoirs: Practical Exploration and Development Strategies, January 19 \& 20, 1998, Denver, Colorado, 201-224. 